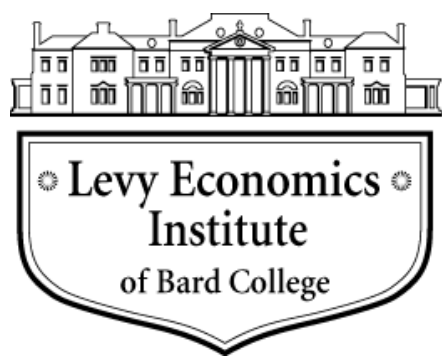

Working Paper No. 962

\title{
Some Empirical Models of Japanese Government Bond Yields Using Daily Data
}

\author{
by \\ Tanweer Akram \\ General Motors \\ and \\ Huiqing Li \\ Central University of Finance and Economics
}

July 2020

The Levy Economics Institute Working Paper Collection presents research in progress by Levy Institute scholars and conference participants. The purpose of the series is to disseminate ideas to and elicit comments from academics and professionals.

Levy Economics Institute of Bard College, founded in 1986, is a nonprofit, nonpartisan, independently funded research organization devoted to public service. Through scholarship and economic research it generates viable, effective public policy responses to important economic problems that profoundly affect the quality of life in the United States and abroad.

\author{
Levy Economics Institute \\ P.O. Box 5000 \\ Annandale-on-Hudson, NY 12504-5000 \\ http://www.levyinstitute.org
}

Copyright C Levy Economics Institute 2020 All rights reserved

ISSN 1547-366X 


\begin{abstract}
This paper models the dynamics of Japanese government bond (JGB) nominal yields using daily data. Models of government bond yields based on daily data, such as those presented in this paper, can be useful not only to investors and market analysts, but also to central bankers and other policymakers for assessing financial conditions and macroeconomic developments in real time. The paper shows that long-term JGB nominal yields can be modeled using the short-term interest rate on Treasury bills, the equity index, the exchange rate, commodity price index, and other key financial variables.
\end{abstract}

KEYWORDS: Japanese Government Bonds; JGBs; Long-Term Interest Rates; Nominal Bond Yields; Monetary Policy; Bank of Japan; John Maynard Keynes

JEL CLASSIFICATIONS: E43; E50; E58; E60; G10; G12 


\section{INTRODUCTION}

This paper models the evolution of Japanese government bond (JGB) nominal yields using daily data. Models of government bond yields using daily data, such as those presented in this paper, can be quite useful for several reasons. First, models of government bond yields based on daily data can be useful for investors, market analysts, and portfolio managers for assessing fundamental valuation and making investment decisions concerning duration, convexity, speculation, and hedging. Second, such models can be useful for policymakers and central bankers for assessing the effects of the monetary transmission mechanism, the management of government debt and Treasury operations, coordination of activities between the Treasury and the central bank, and evaluation of financial stability in real time. Third, models of government bond yields based on daily data have a much larger number of observations than those based on quarterly and monthly data. This allows for a greater degree of freedom and the application of a wide range of econometric techniques than in those models with quarterly or monthly data.

This paper contributes to the ongoing debate about the causes of JGBs' low and negative nominal yields. In recent years, there has been an animated debate about what has kept JGB yields so low and whether such yields are sustainable.

Two fundamentally different schools of thought exist on the dynamics of government bond yields. The conventional view holds that the low yields of JGBs are not sustainable and that the Japanese government faces the risk of high inflation, elevated government bond yields, currency depreciation, and debt default. This view is represented by various analysts who have modeled JGB dynamics, such as Atasoy, Ertuğrul, and Ozun (2014), Doi, Hoshi, and Okimoto (2011), Hansen and İmrohoroğlu (2013), Horioka, Nomoto, and Terada-Hagiwara (2014), and Hoshi and Ito (2012, 2013, and 2014). This conventional view is also shared by various authors, such as Baldacci and Kumar (2010), Gruber and Kamin (2012), Paccagnini (2016), and Poghosyan (2014), who have analyzed government bonds yields in other advanced economies. Reinhart and Rogoff's (2009) widely published book is an epitome of the concern that elevated government debt and deficit ratios can lead to adverse and malignant economic outcomes, such as high 
inflation, higher government bond yields, increased likelihood of financial crisis and debt default, and slow economic growth.

In contrast to the conventional wisdom, the Keynesian view regards the low JGB yields primarily as an outcome of the Bank of Japan's (BoJ) monetary policy actions. In particular, the BoJ's decision to maintain ultra-low or even negative policy rates and other monetary policy actions is seen as the main contributing factor to low yields. This view that the central bank's actions have a decisive influence on the long-term interest rate of government bonds originates from Keynes's (1930) assertion. Keynes based his views on Riefler's (1930) observations and statistical analysis. In recent years, Akram and Das (2014a, 2014b) and Akram and Li (2018) have modeled JGB yields from a Keynesian perspective. This is a part of a broader research agenda of modeling the dynamics of government bond yields as being primarily driven by the central bank's actions. This view is articulated in Akram and Das (2015, 2017, and 2019), Akram and Li (2016, 2017, 2019a, 2019b), Simoski (2019), Vinod, Chakraborty, and Karun (2014), and others. These authors have examined the dynamics of government bonds for several countries and regions, including advanced countries and regions, such as the United States and the eurozone, and emerging markets, such as India, Brazil, and Mexico.

The Keynesian view not only derives from Keynes's (1930, [1936]2007) assertions, but is also inspired by discussions in Davidson (2015), Fullwiler (2016, [2008]2017), Kregel (2011), Lavoie (2014), Lerner (1943, 1947), Mattos et al. (2019), Sau (2018), Tcherneva (2011), and Wray ([1998]2003, 2012). The findings of this paper reinforce the Keynesian case for modeling government bond yields as being driven by the central bank's actions in setting the policy rate and through other monetary policy actions.

\subsection{Outline}

This paper is arranged as follows. Section 2 describes the evolution of nominal yield of JGBs and puts this in the context of developments in the Japanese economy. Section 3 explains the data and its sources. Section 4 is the empirical part of the paper. It contains tests for unit roots and cointegration, specification and estimation of the underlying models, interpretation of the 
results, and stability tests. Section 5 discusses the economic and policy implications of the findings. Section 6 concludes with a summary and the relevance of the findings.

\section{THE EVOLUTION AND MACRO DYNAMICS OF JGB NOMINAL YIELDS}

The evolution of JGBs' nominal yields since 1980 reveals that they fell sharply in the early 1990s and have stayed low since then (figure 1). Since the turn of the 21 st century, the yields on JGBs have remained extremely low. JGB yields declined in the aftermath of the recessions initiated by the global financial crisis and the Tohoku earthquake, and the launch of the BoJ's quantitative and qualitative monetary easing (QQME) program. Nominal yields on JGBs crossed into negative territory in early 2016, as the BoJ's policy shifted to a combination of yield curve control with QQME.

The BoJ's policy rate and the short-term interest rate fell in the mid-1990s and have stayed low since then (figure 2). While there have been some changes and important innovations in monetary policy from time to time, the BoJ's monetary policy has been highly accommodative overall. The short-term interest rate declined notably in 2015 in anticipation of a move to negative policy rates.

Japan's economy is characterized by low inflation and deflationary dynamics. Core inflation has been extraordinarily low. And the deflationary dynamics are entrenched in the economy and well reflected in the deflators for real GDP and various aggregate demand expenditure components.

The close connection between the short-term interest rate and the long-term interest rate is illustrated in numerous scatterplots (figures 3-26). These scatterplots reveal two things: (1) the strong correlation between JGBs of various maturity tenors to the yields of 3-month Treasury bills; and (2) the positive correlation between year-over-year percentage point changes in the yields of JGBs of various maturity tenors and 3-month Treasury bills. 
Figure 27 illustrates the evolution of year-over-year percentage point changes in the JGB yields of selected tenors and in the Nikkei index.

Figure 28 illustrates the evolution of the yields of 10-year JGBs and the exchange rate as measured by: (1) yen per US dollar and (2) yen per euro.

Garside (2012), Akram (2014, 2016, and 2019), Kurihara (2015), Radalet and Sachs (1998), and the Institute for Monetary and Economic Studies (2012) provide more comprehensive coverage of Japan's economic evolution, policy issues, and challenges ahead. 
Figure 1: The Evolution of JGB Nominal Yields, 2000-18

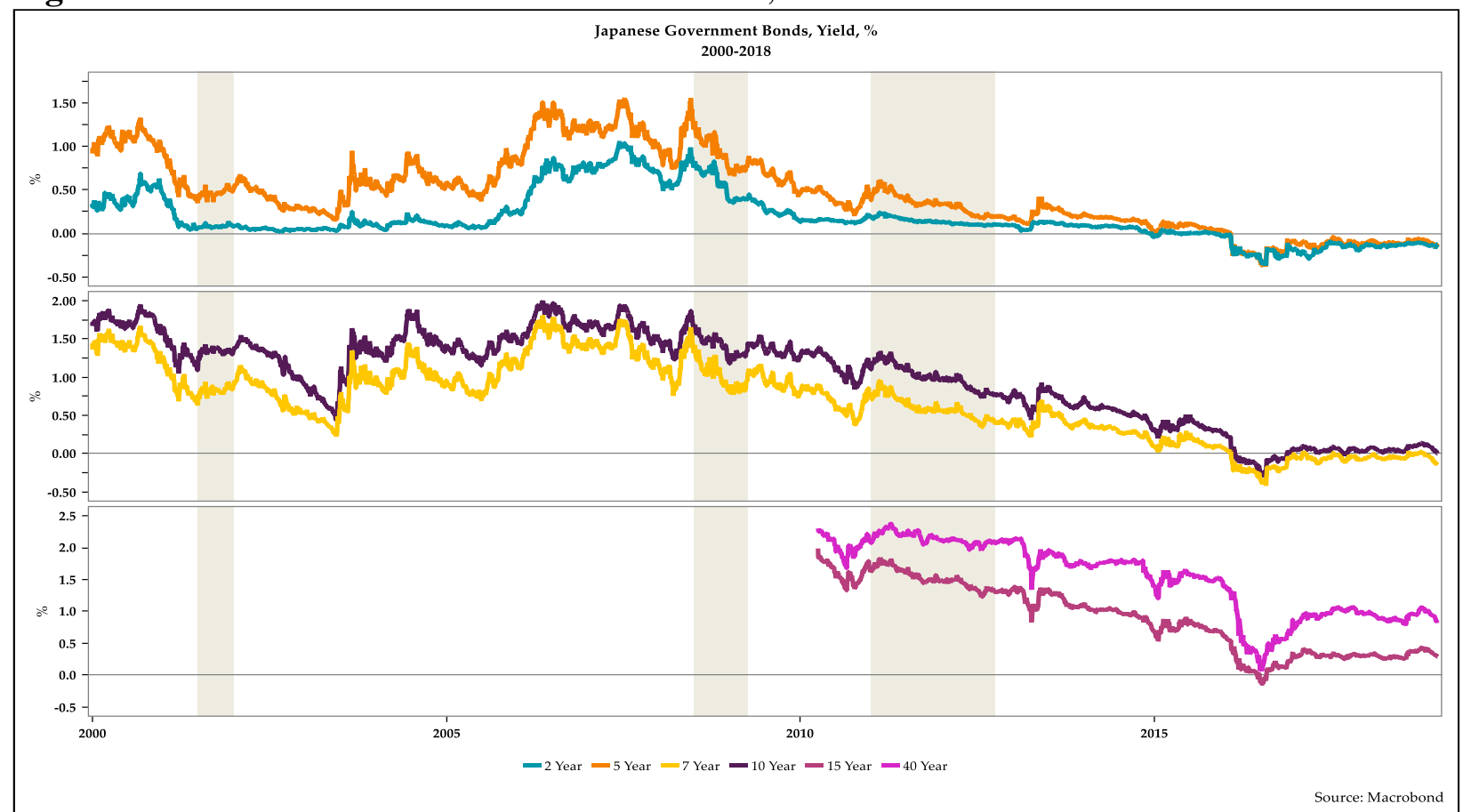

Figure 2: The Evolution of the BoJ's Policy Rates and Short-Term Interest Rates, 2000-18

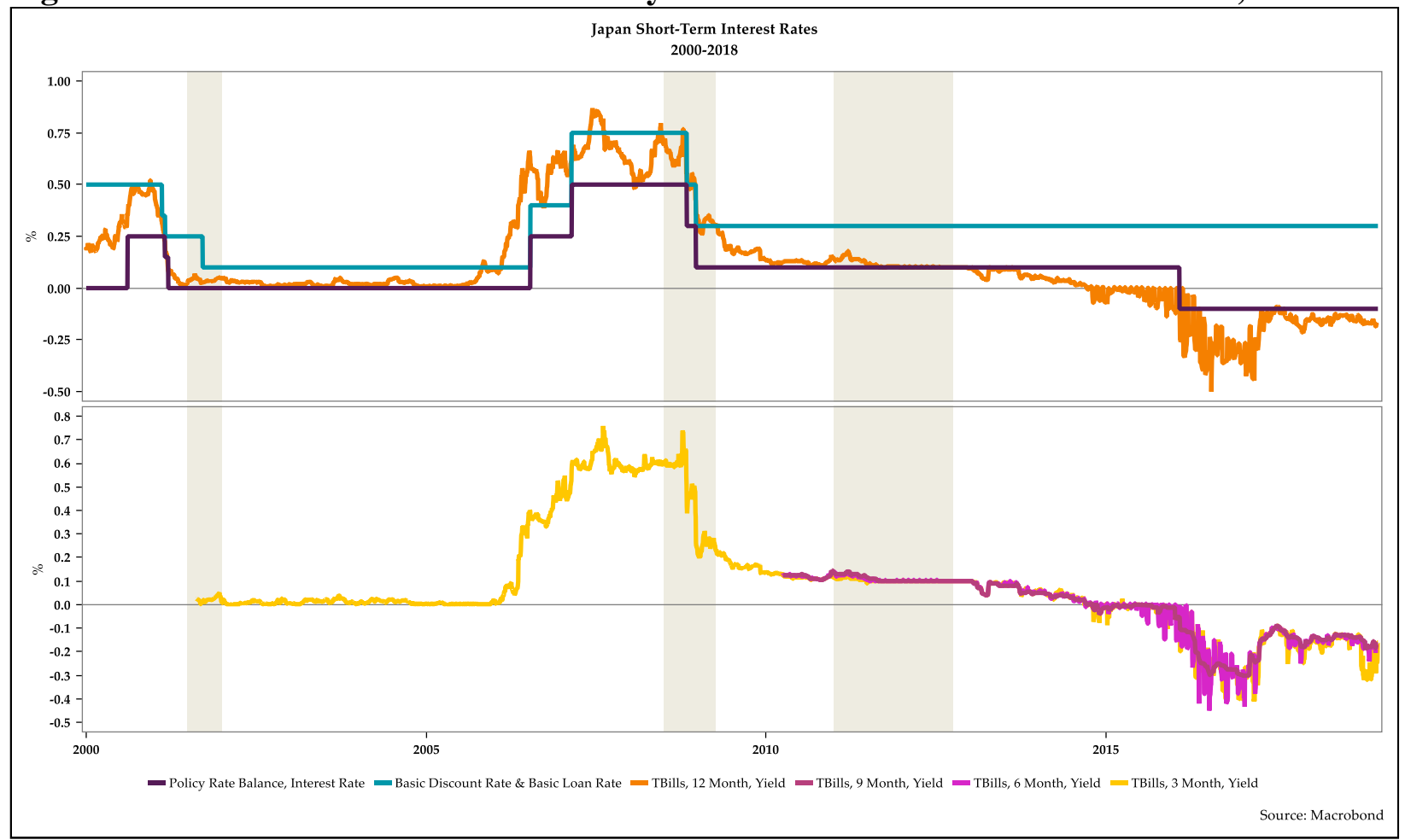


Figure 3: Scatterplot of the Yields of 2-Year JGBs and 3-Month Treasury Bills, 2002-18

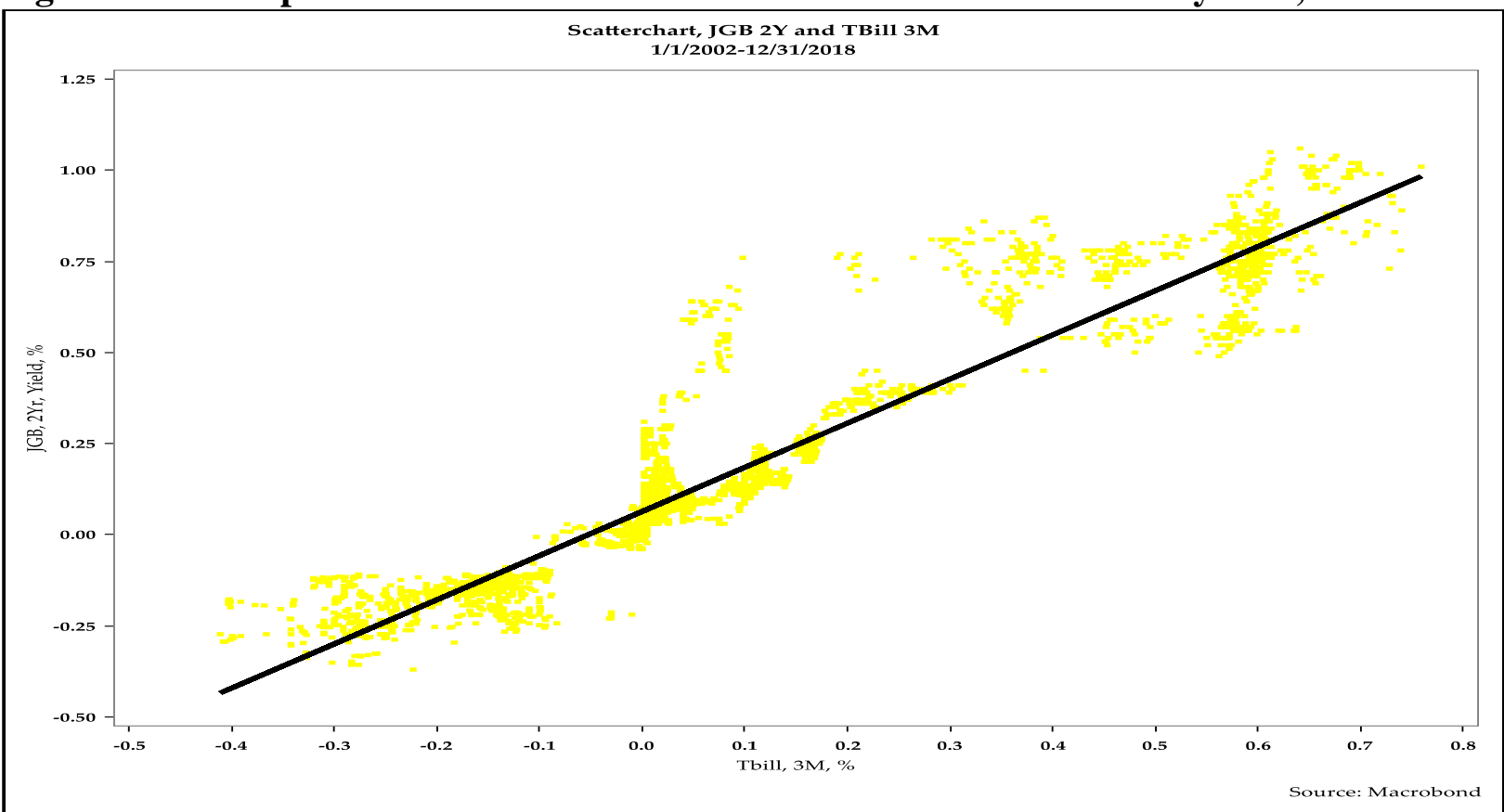

Figure 4: Scatterplot of Year-Over-Year Percentage Point Changes in the Yields of 2-Year JGBs and 3-Month Treasury Bills, 2002-18

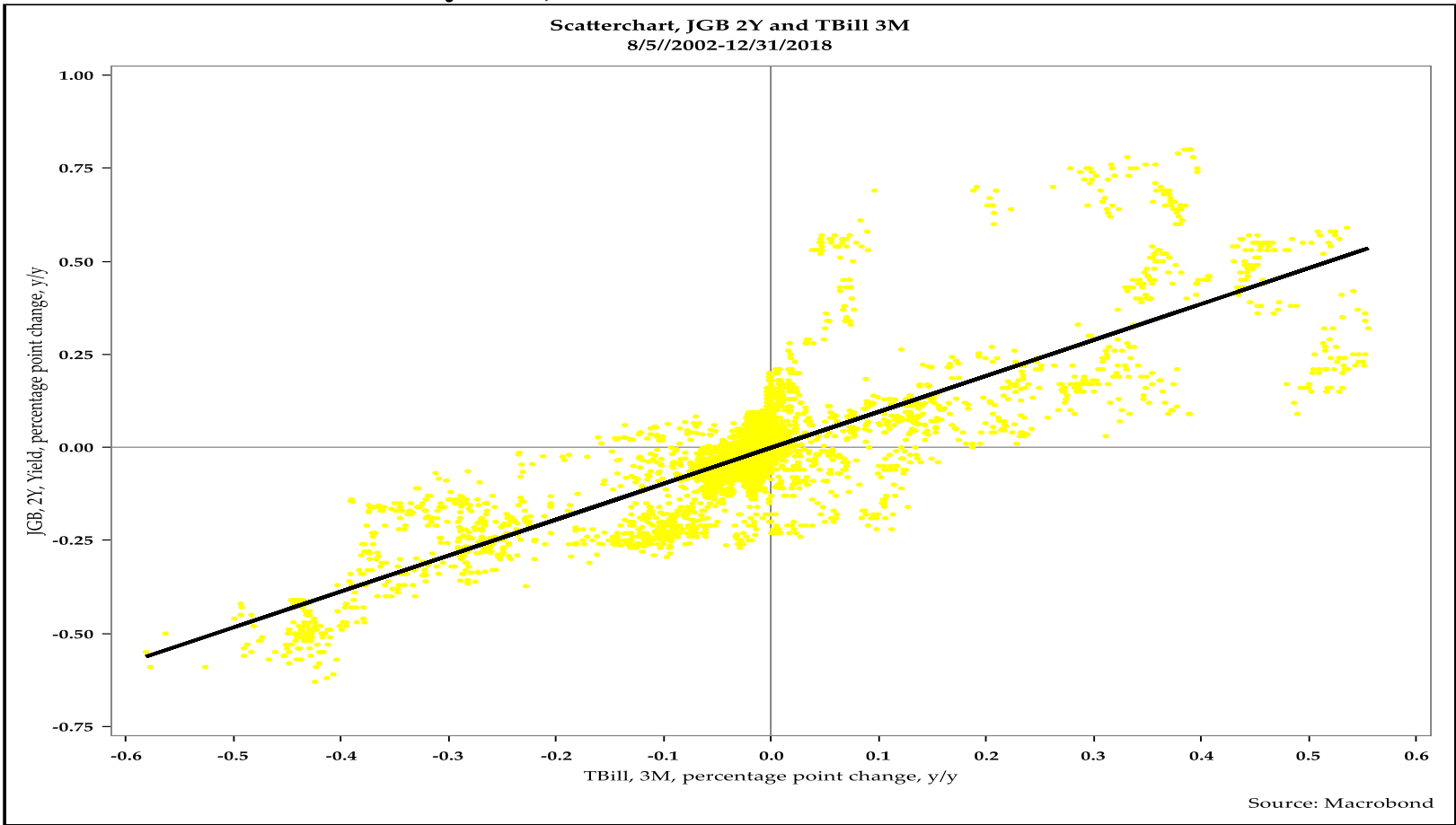


Figure 5: Scatterplot of the Yields of 3-Year JGBs and 3-Month Treasury Bills, 2002-18

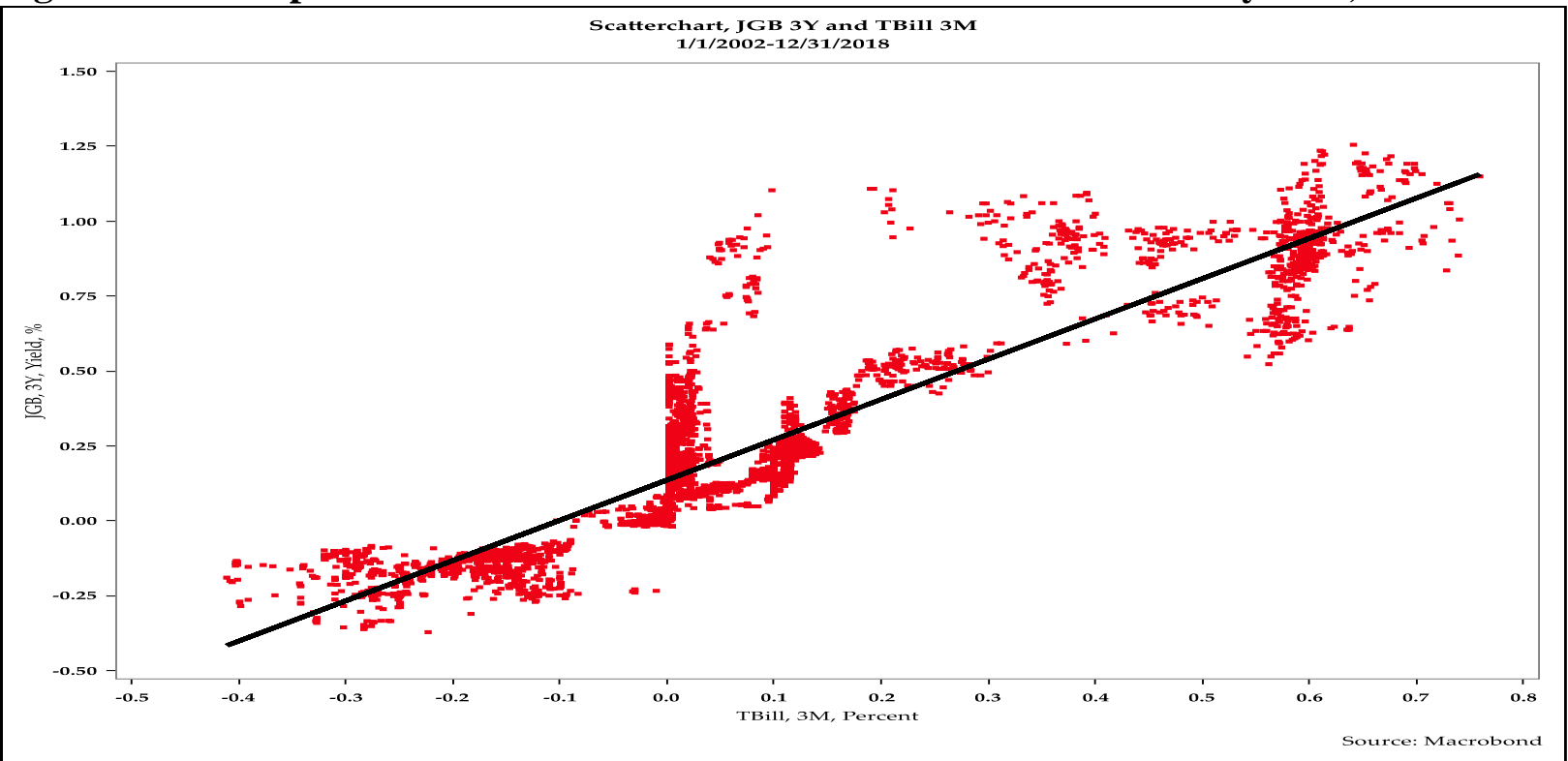

Figure 6: Scatterplot of Year-Over-Year Percentage Point Changes in the Yields of 3-Year JGBs and 3-Month Treasury Bills, 2002-18

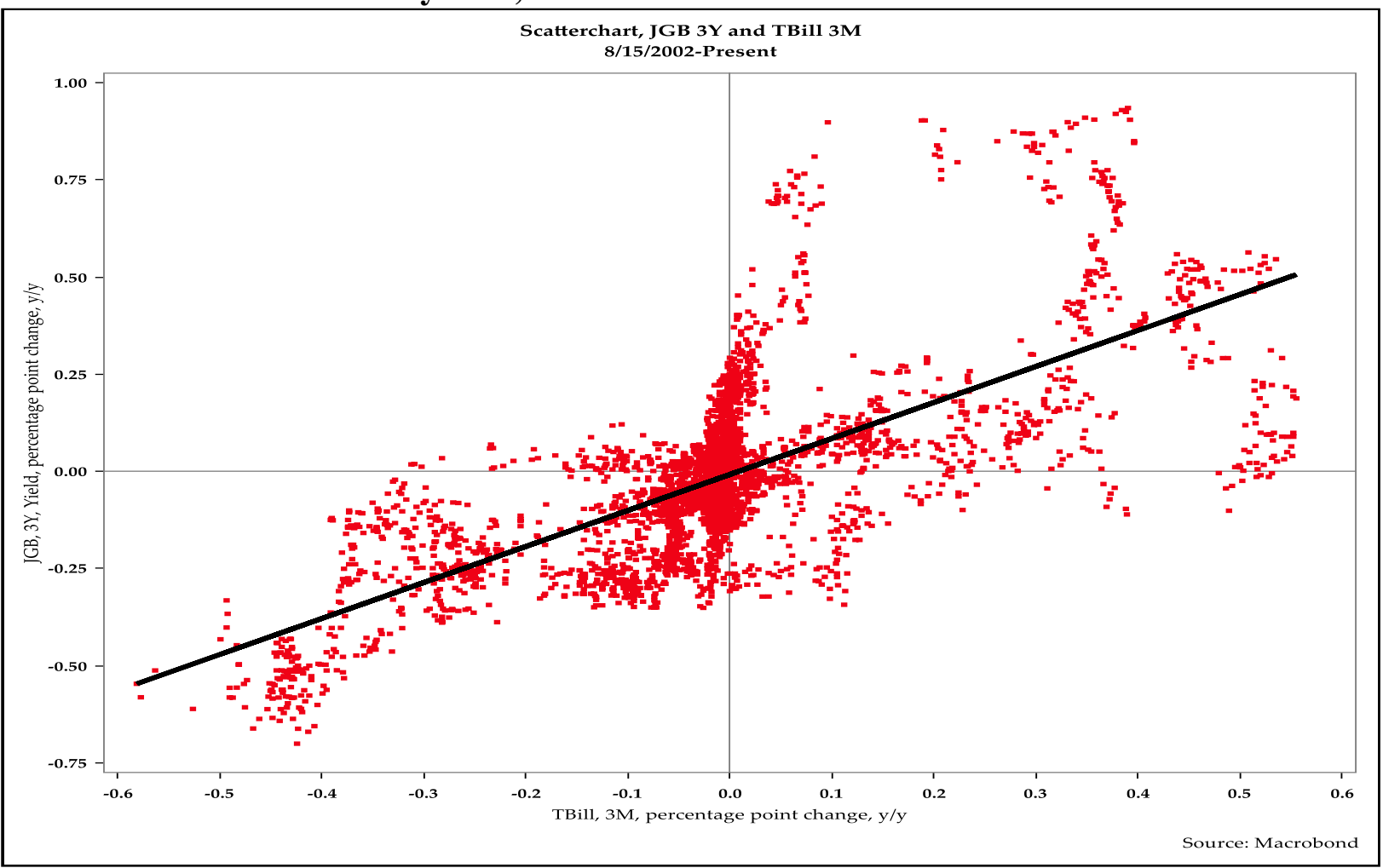


Figure 7: Scatterplot of the Yields of 4-Year JGBs and 3-Month Treasury Bills, 2002-18

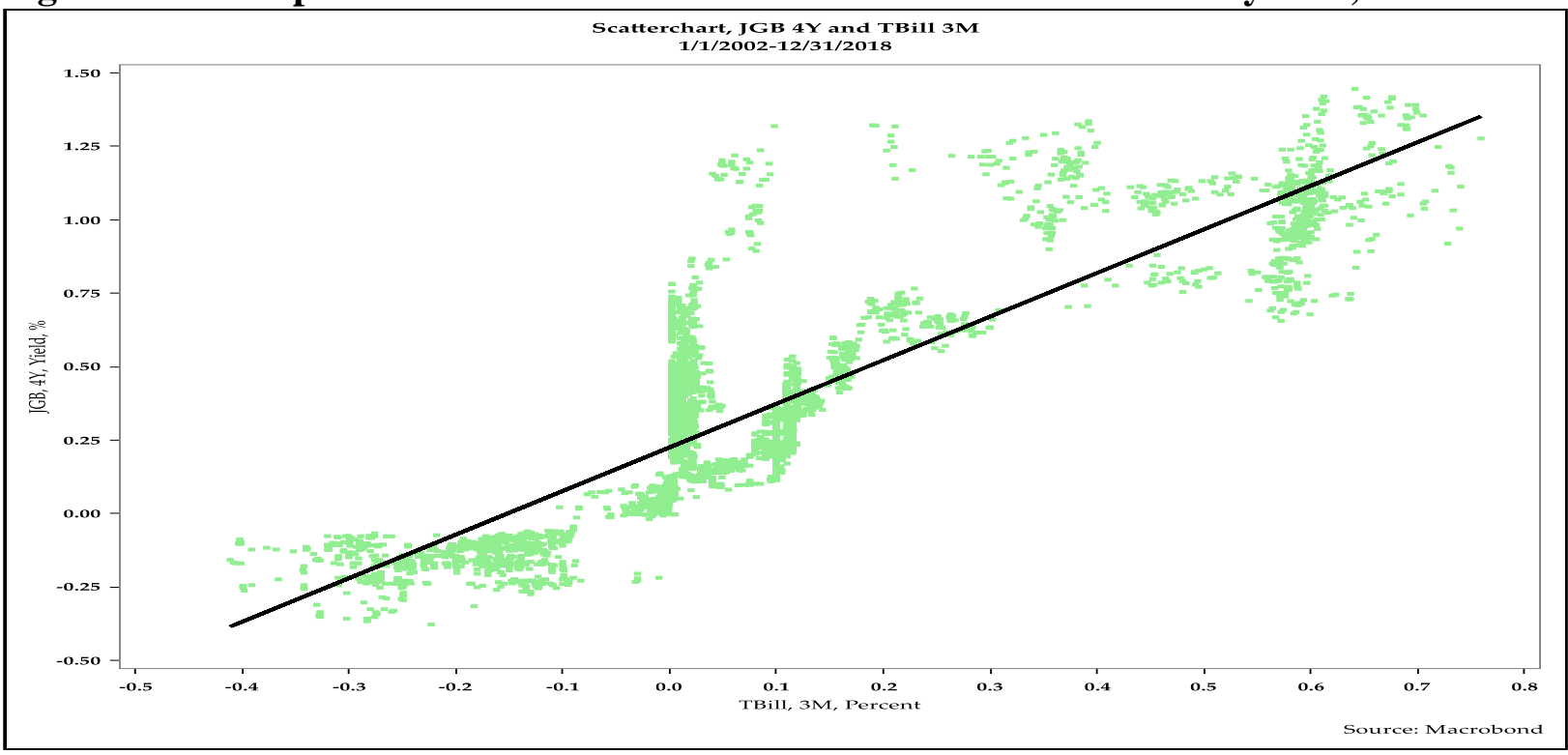

Figure 8: Scatterplot of Year-Over-Year Percentage Point Changes in the Yields of 4-Year JGBs and 3-Month Treasury Bills, 2002-18

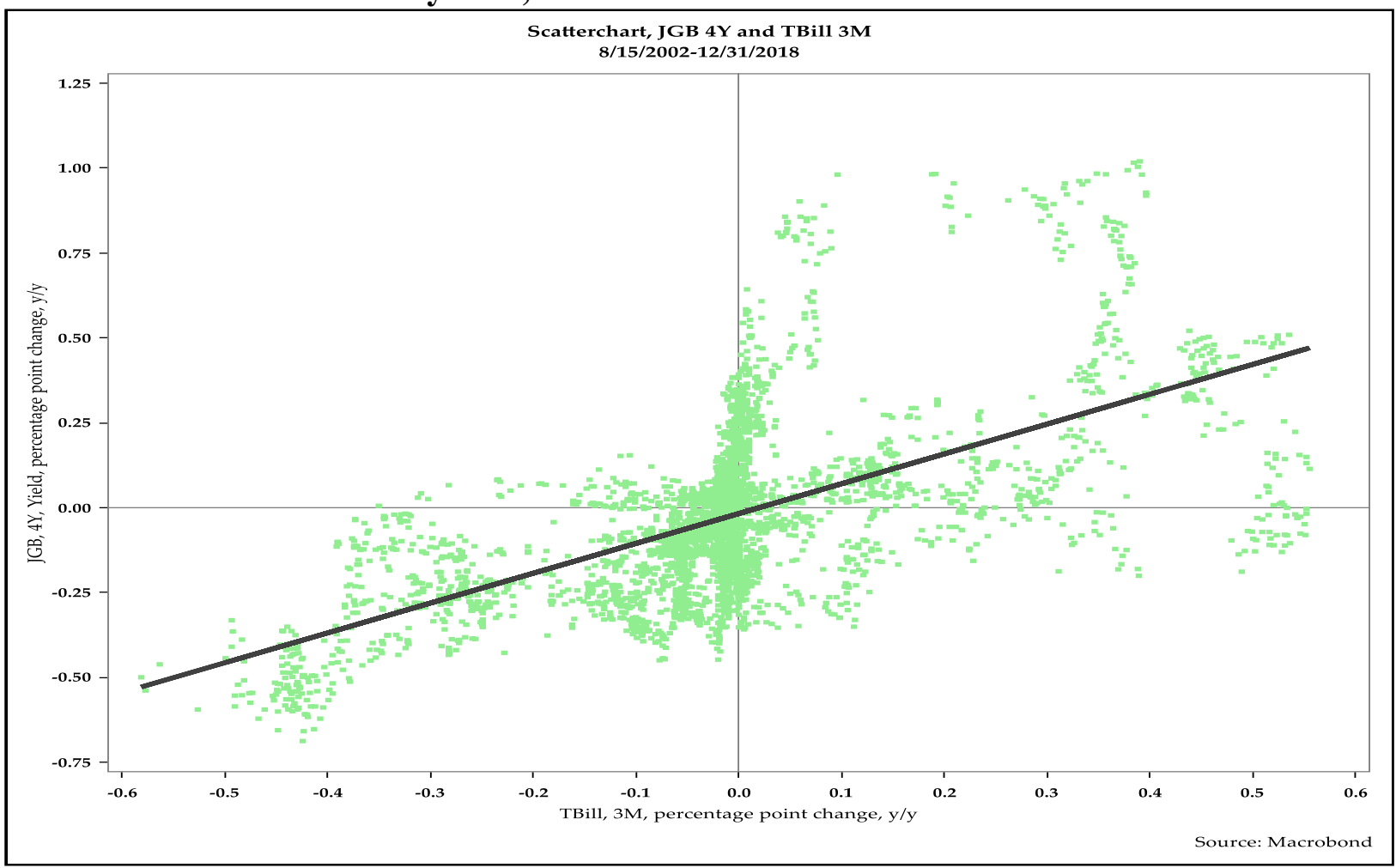


Figure 9: Scatterplot of the Yields of 5-Year JGBs and 3-Month Treasury Bills, 2002-18

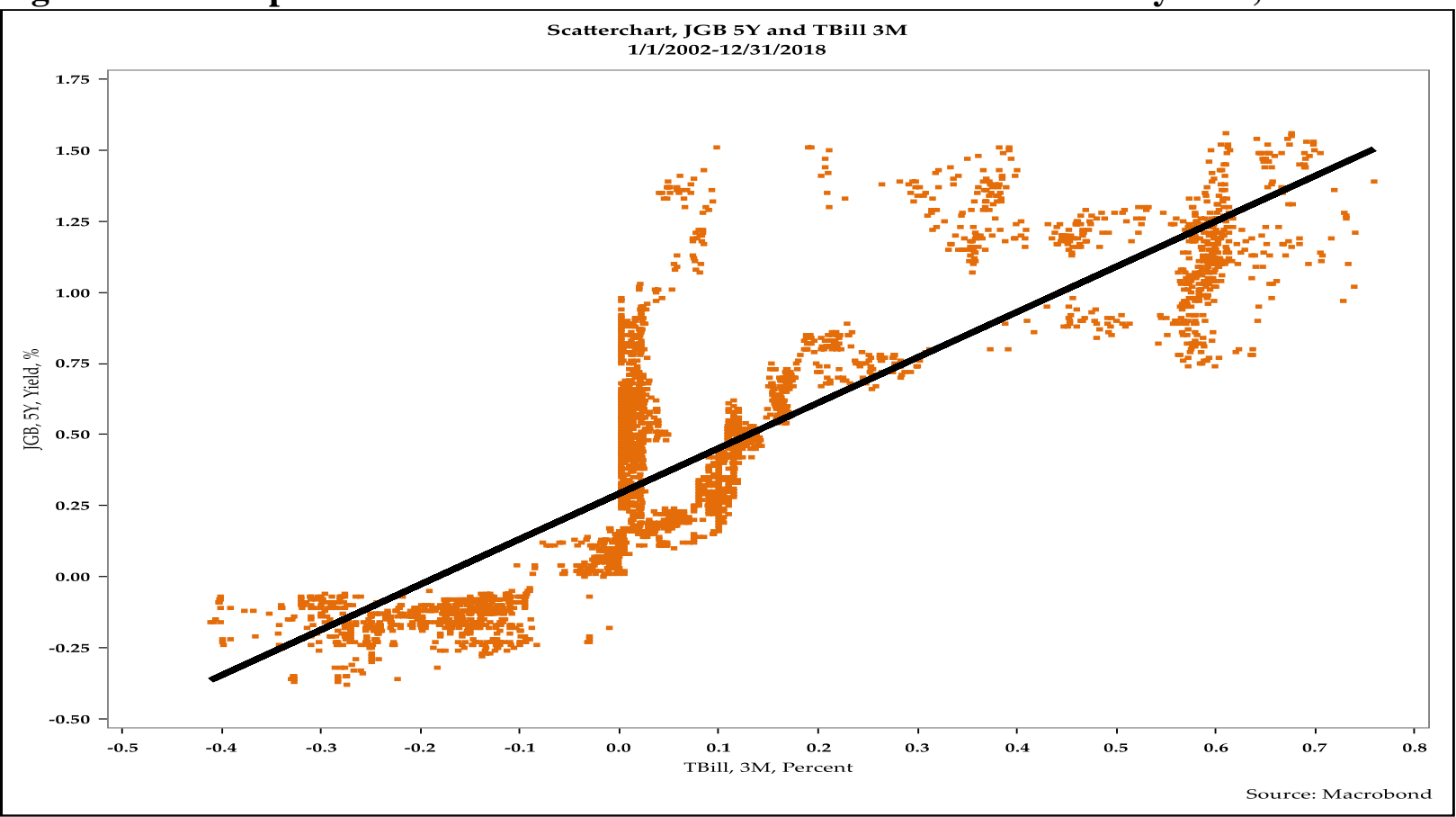

Figure 10: Scatterplot of the Year-Over-Year Percentage Point Changes in the Yields of 5Year JGBs and 3-Month Treasury Bills, 2002-18

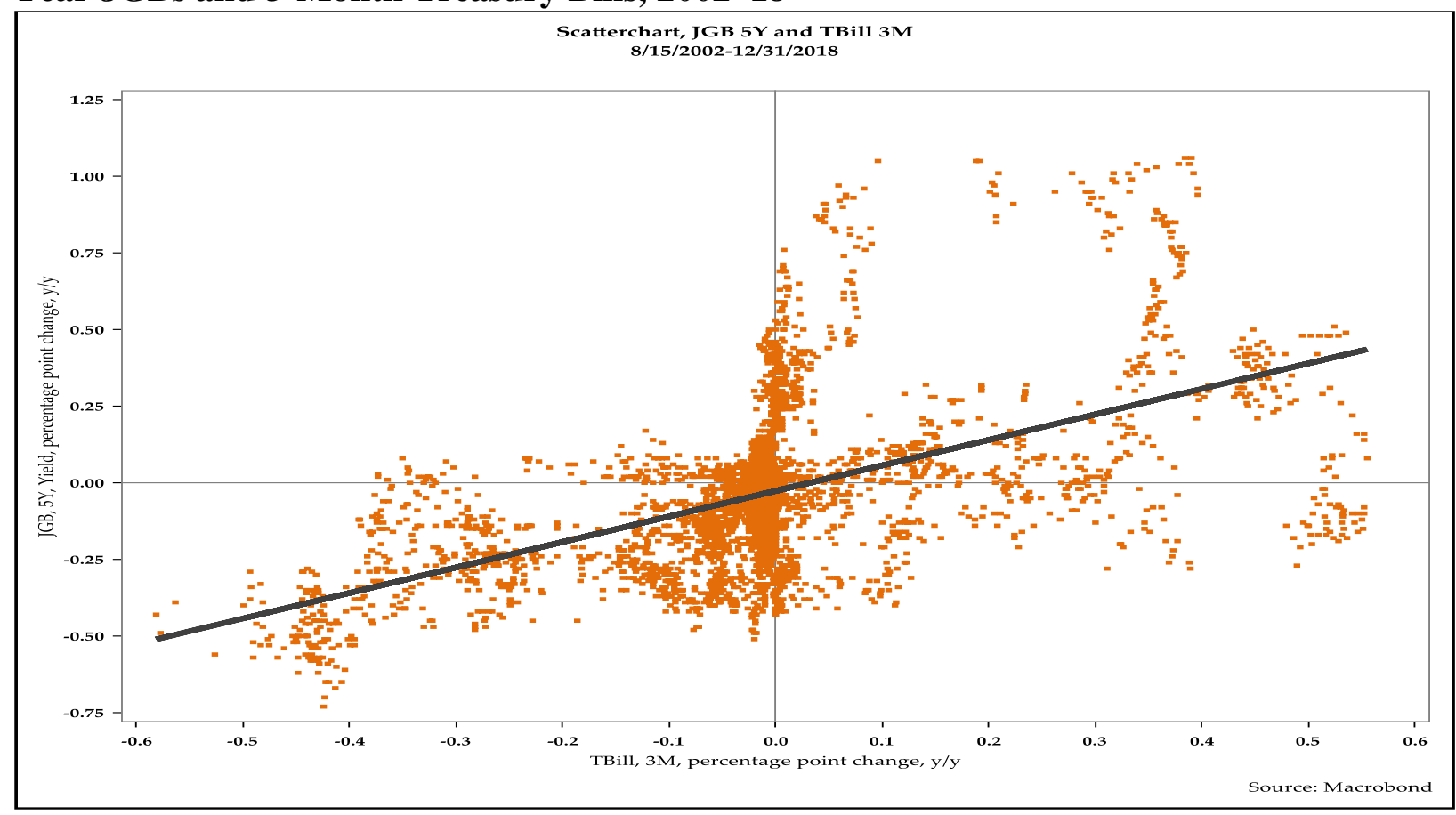


Figure 11: Scatterplot of the Yields of 6-Year JGBs and 3-Month Treasury Bills, 2002-18

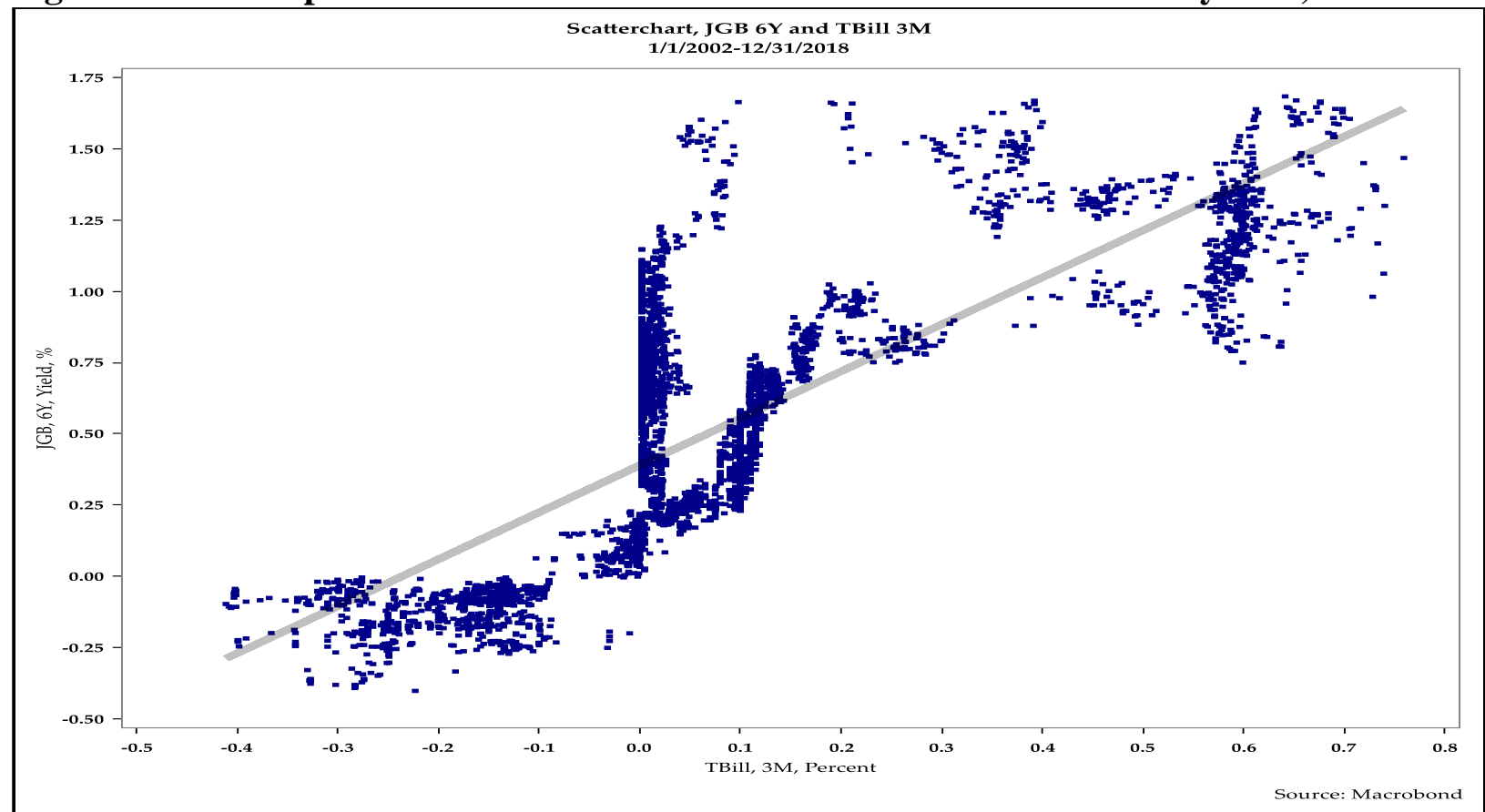

Figure 12: Scatterplot of Year-Over-Year Percentage Point Changes in the Yields of 6Year JGBs and 3-Month Treasury Bills, 2002-18

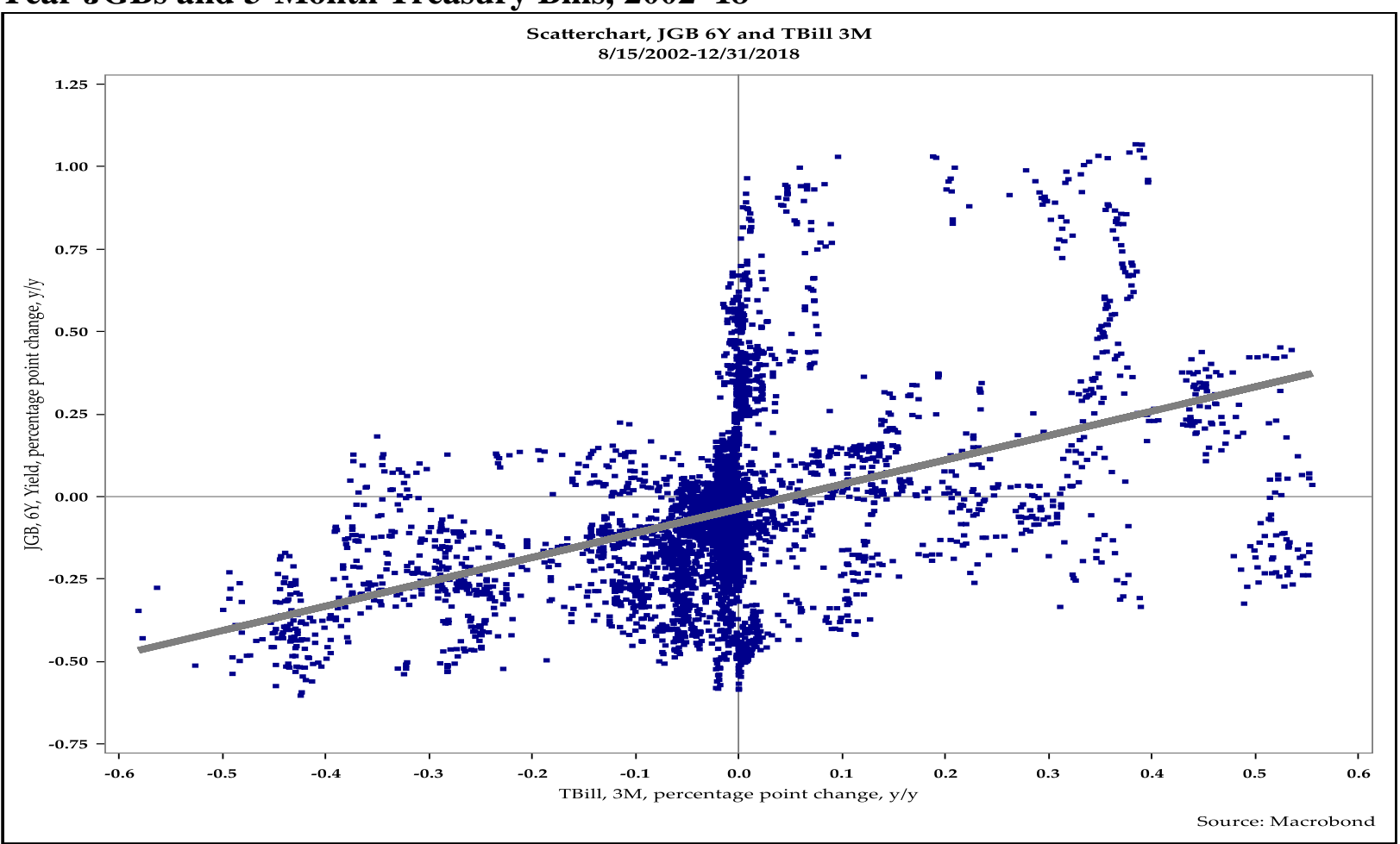


Figure 13: Scatterplot of the Yields of 7-Year JGBs and 3-Month Treasury Bills, 2002-18

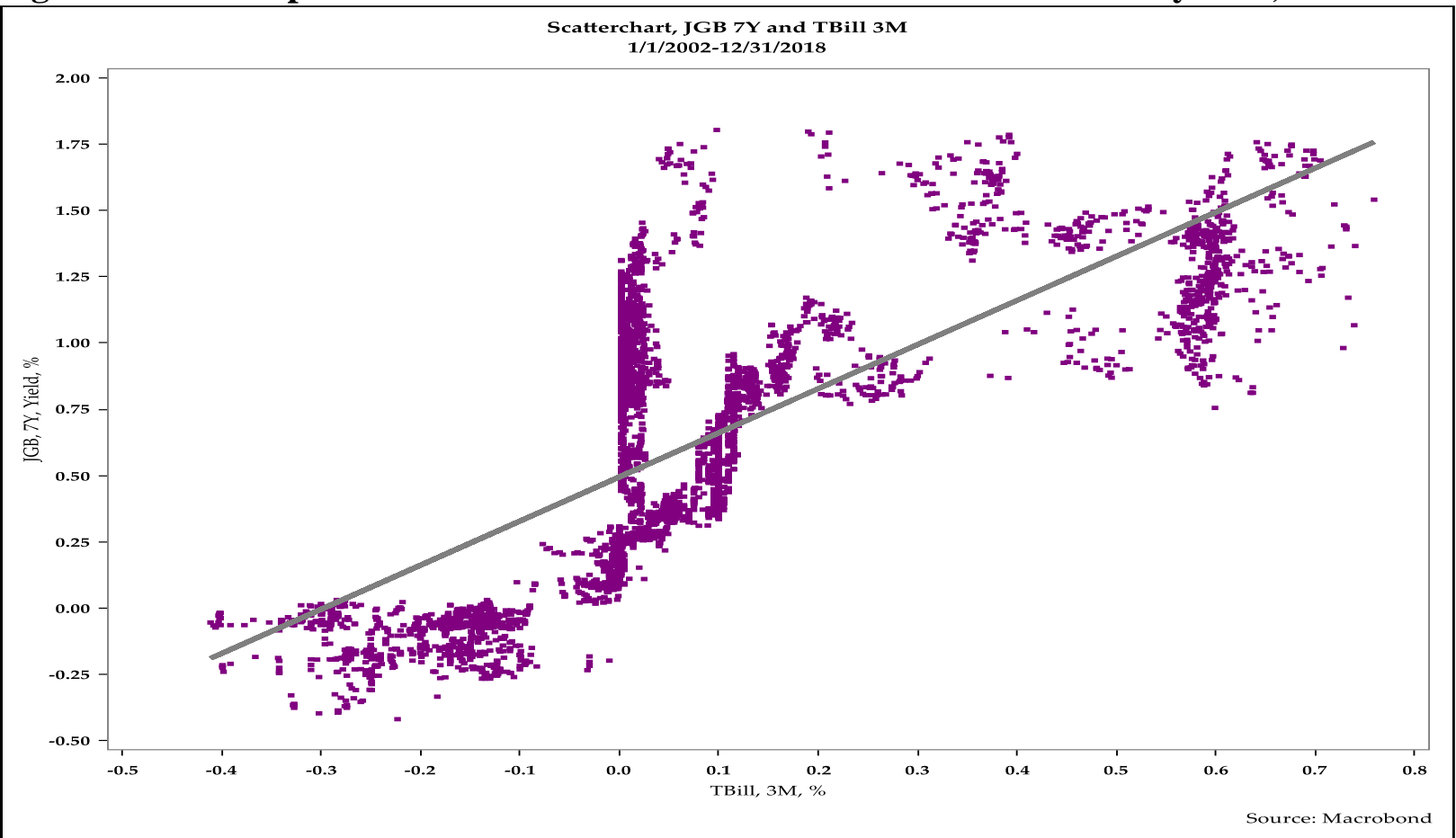

Figure 14: Scatterplot of Year-Over-Year Percentage Point Changes in the Yields of 7Year JGBs and 3-Month Treasury Bills, 2002-18

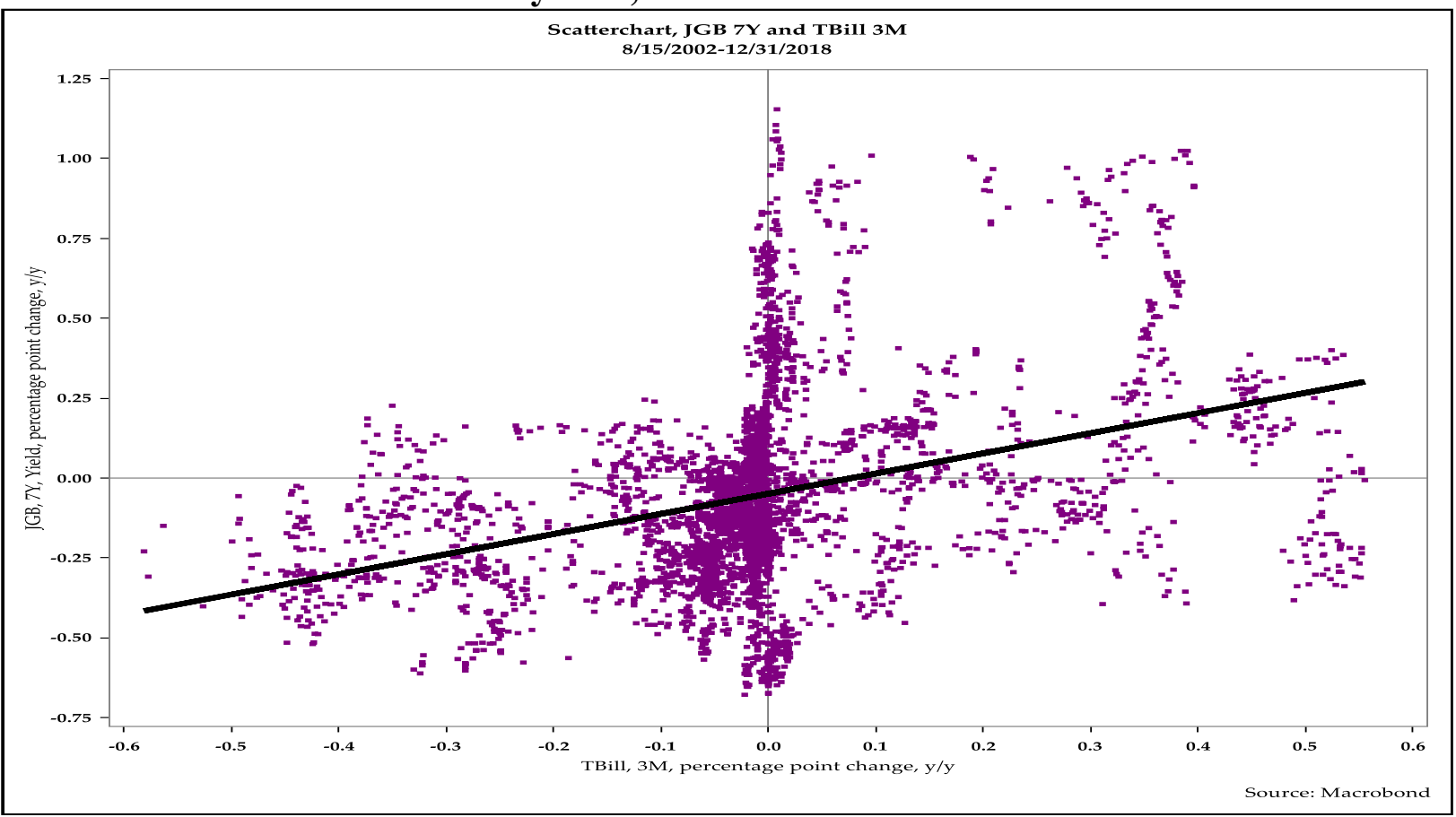


Figure 15: Scatterplot of the Yields of 8-Year JGBs and 3-Month Treasury Bills, 2002-18

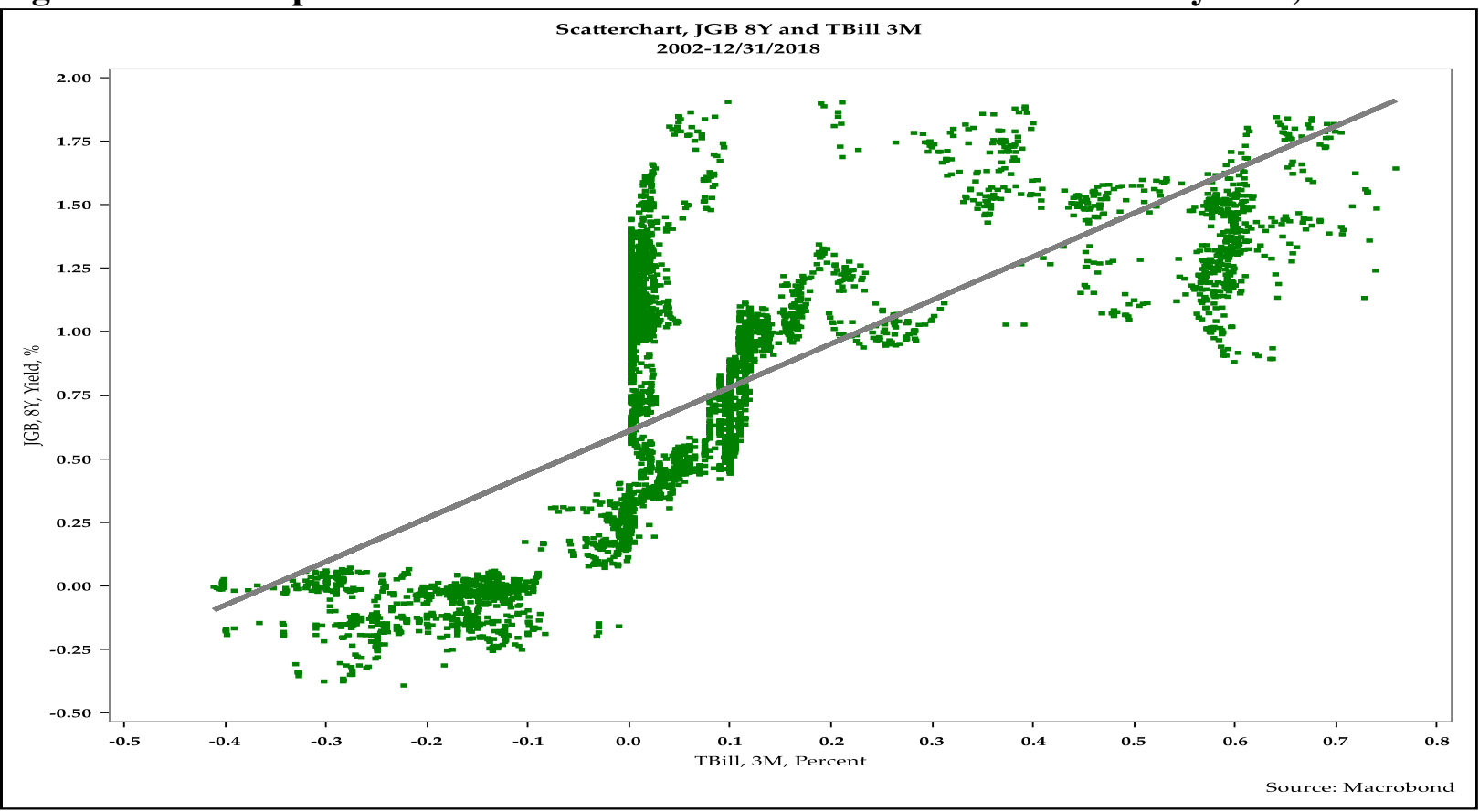

Figure 16: Scatterplot of Year-Over-Year Percentage Point Changes in the Yields of 8Year JGBs and 3-Month Treasury Bills, 2002-18

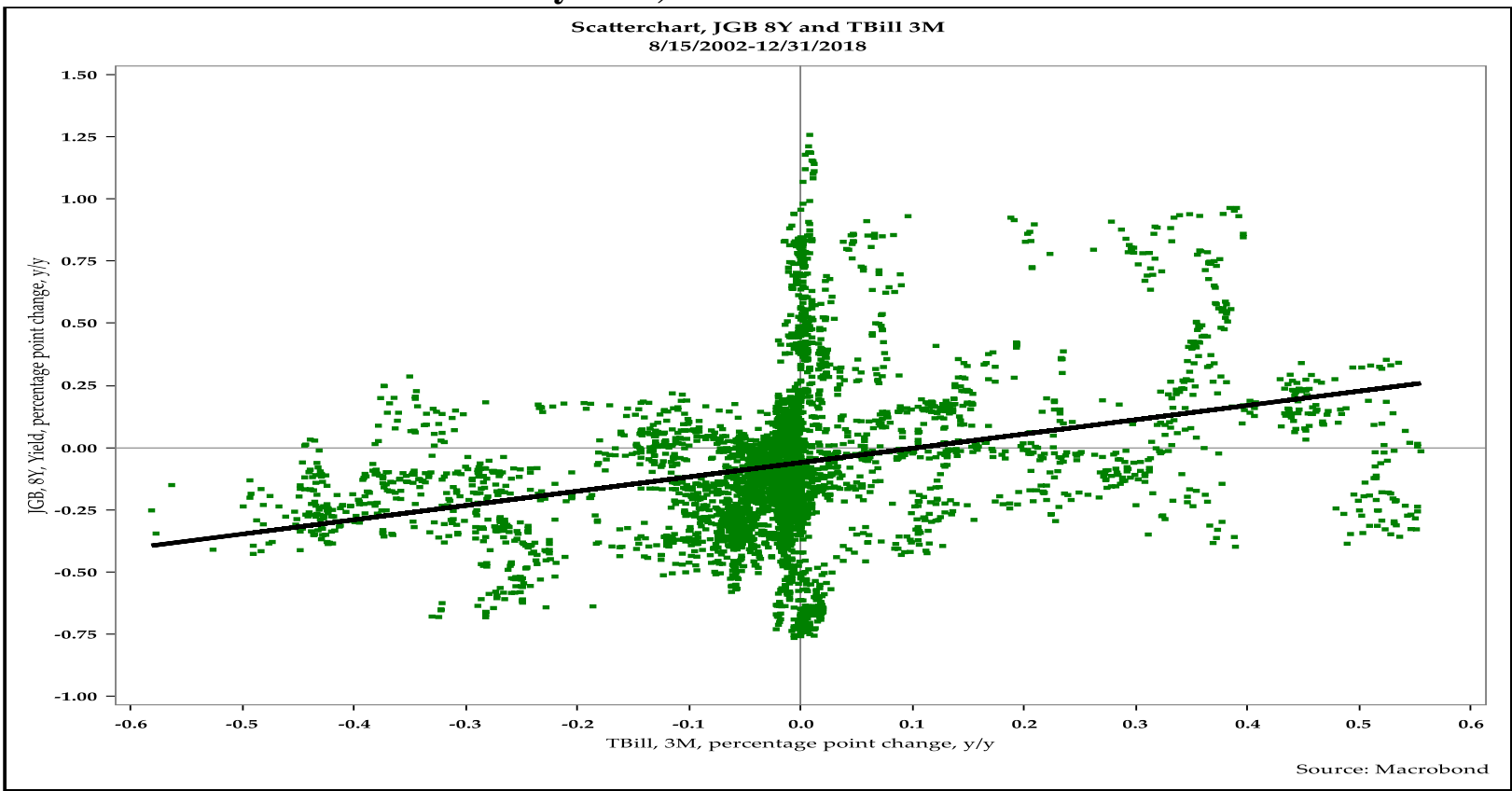


Figure 17: Scatterplot of the Yields of 9-Year JGBs and 3-Month Treasury Bills, 2002-18

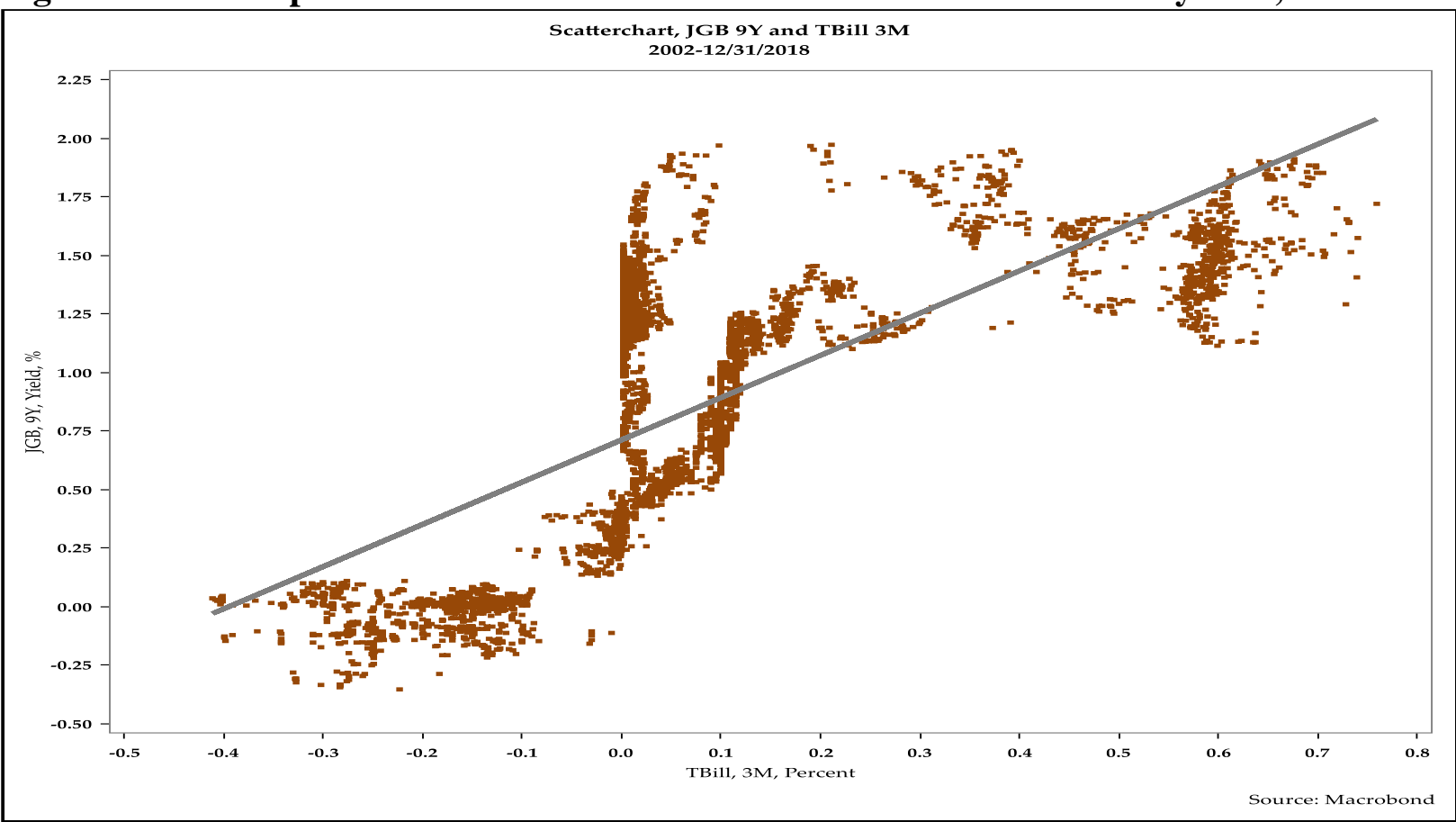

Figure 18: Scatterplot of Year-Over-Year Percentage Point Changes in the Yields of 9Year JGBs and 3-Month Treasury Bills, 2002-18

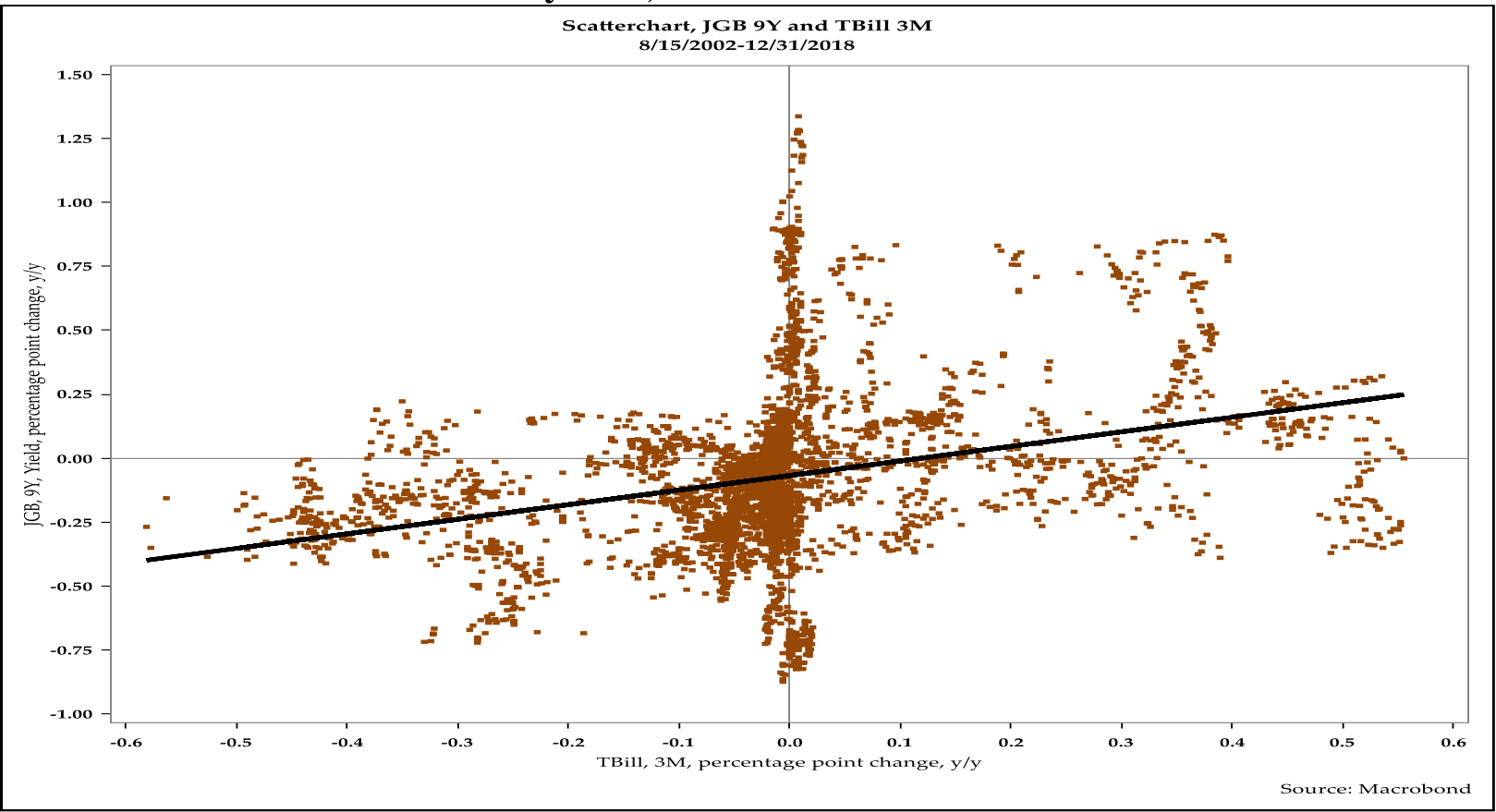


Figure 19: Scatterplot of the Yields of 10-Year JGBs and 3-Month Treasury Bills, 2002-18

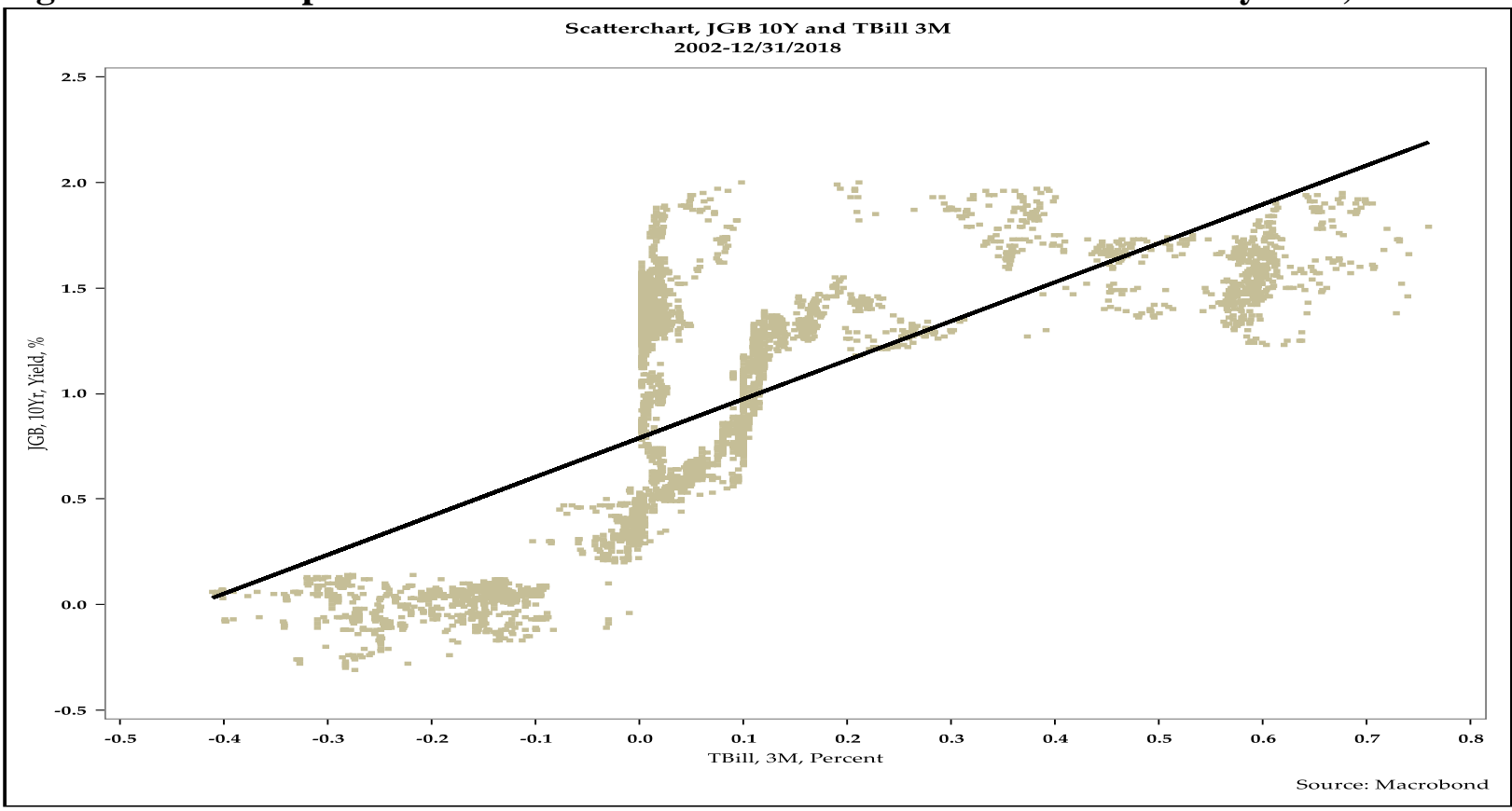

Figure 20: Scatterplot of the Year-Over-Year Percentage Point Changes in the Yields of 10-Year JGBs and 3-Month Treasury Bills, 2002-18

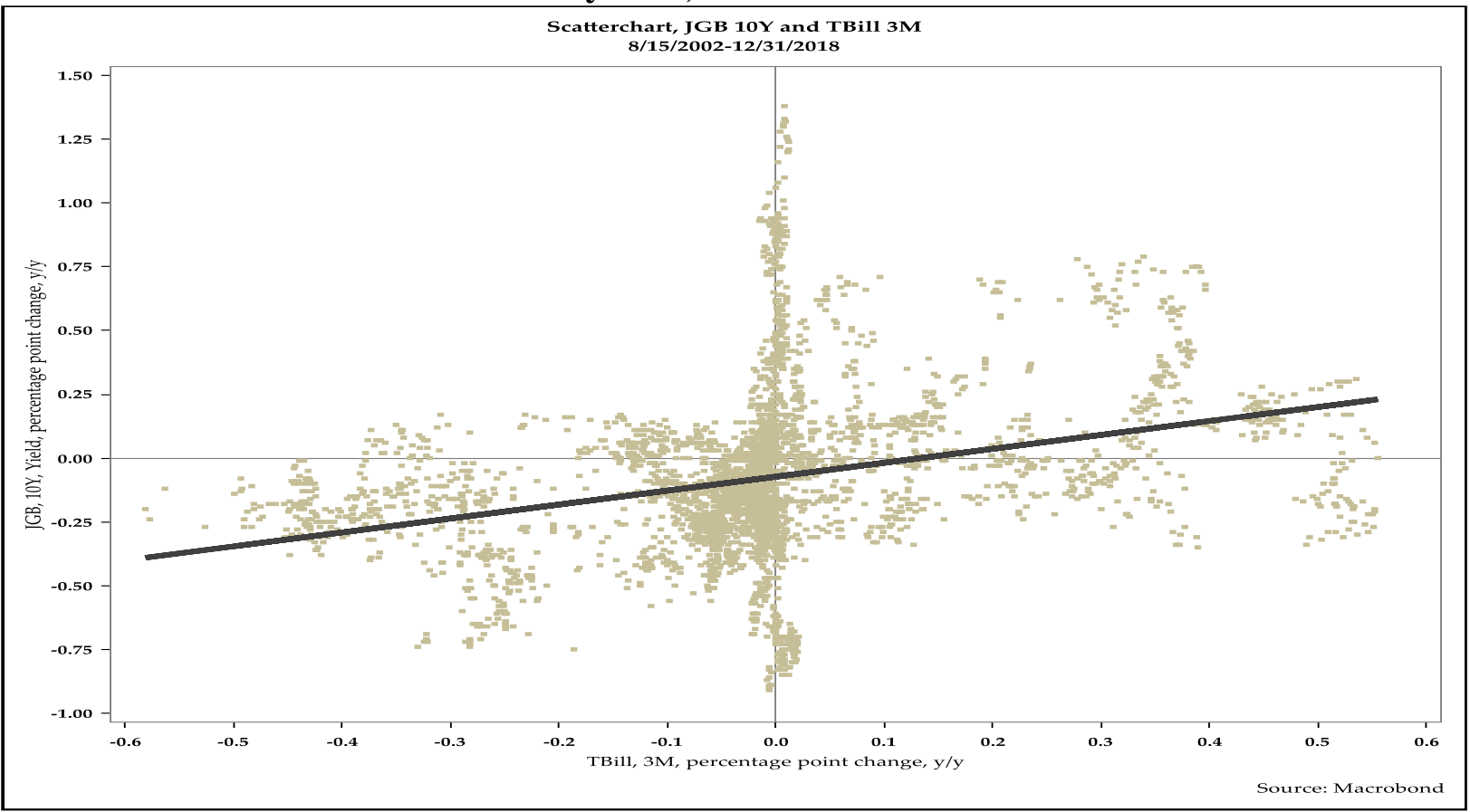




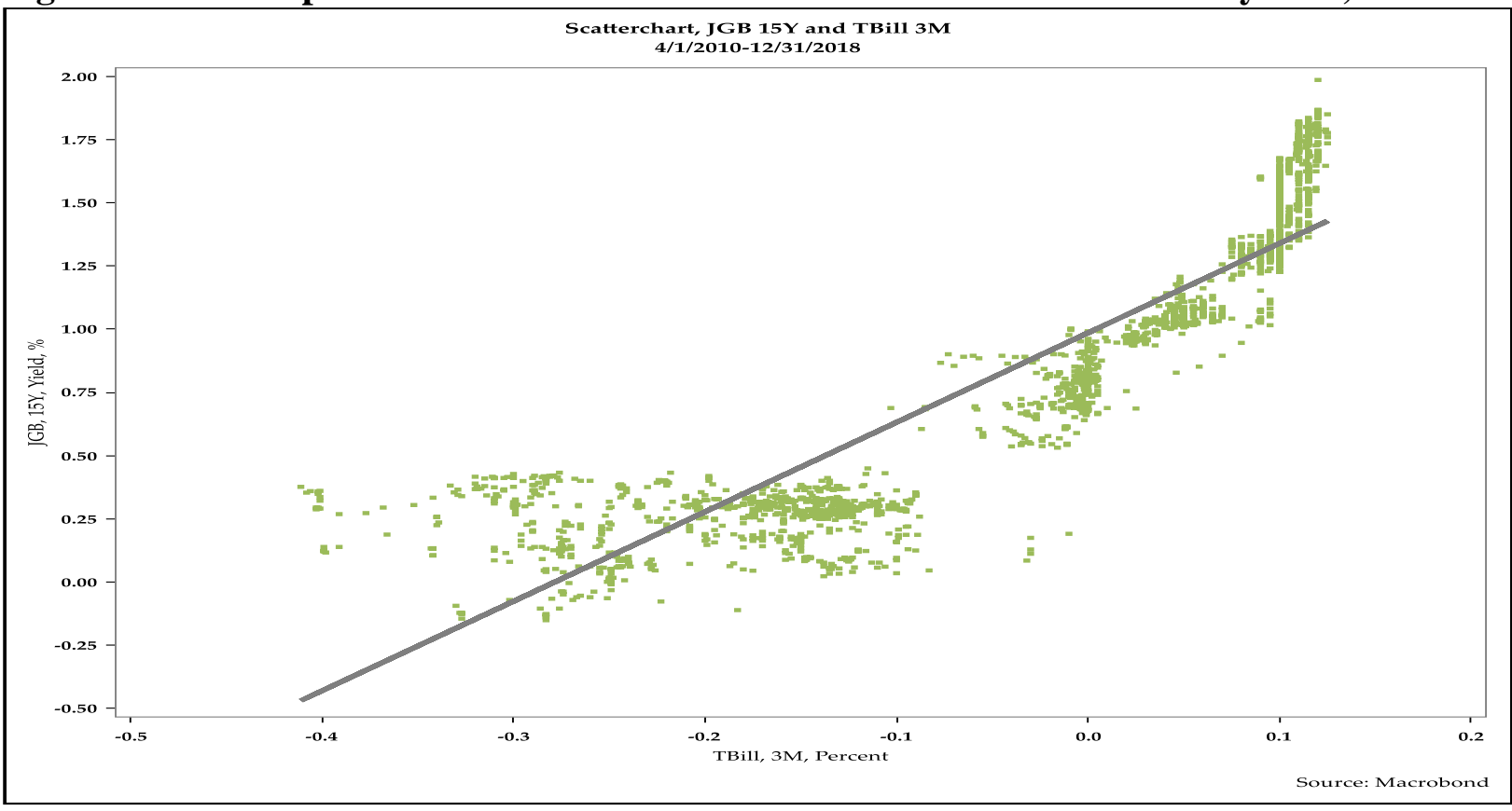

Figure 22: Scatterplot of Year-Over-Year Percentage Point Changes in the Yields of 15Year JGBs and 3-Month Treasury Bills, 2011-18

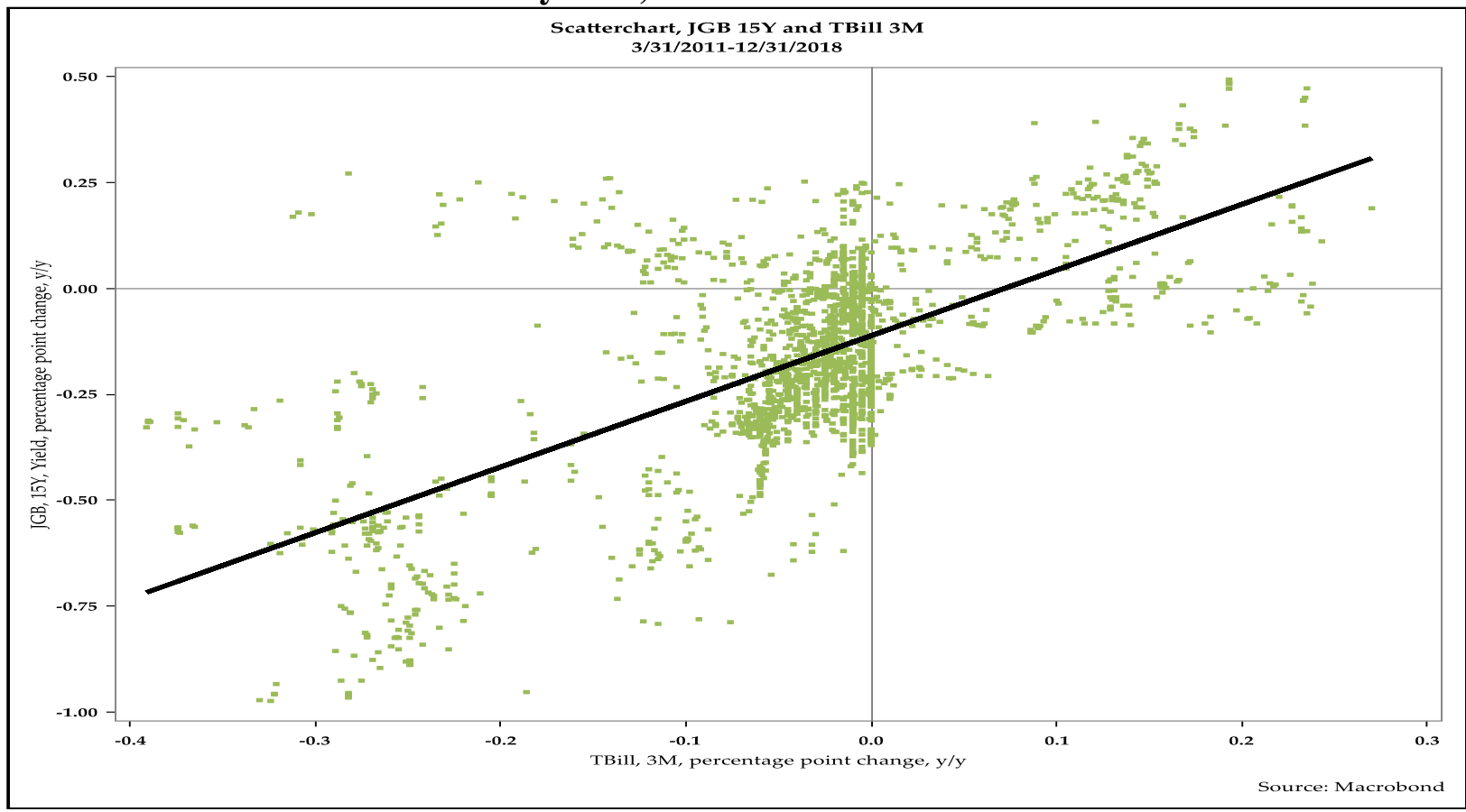




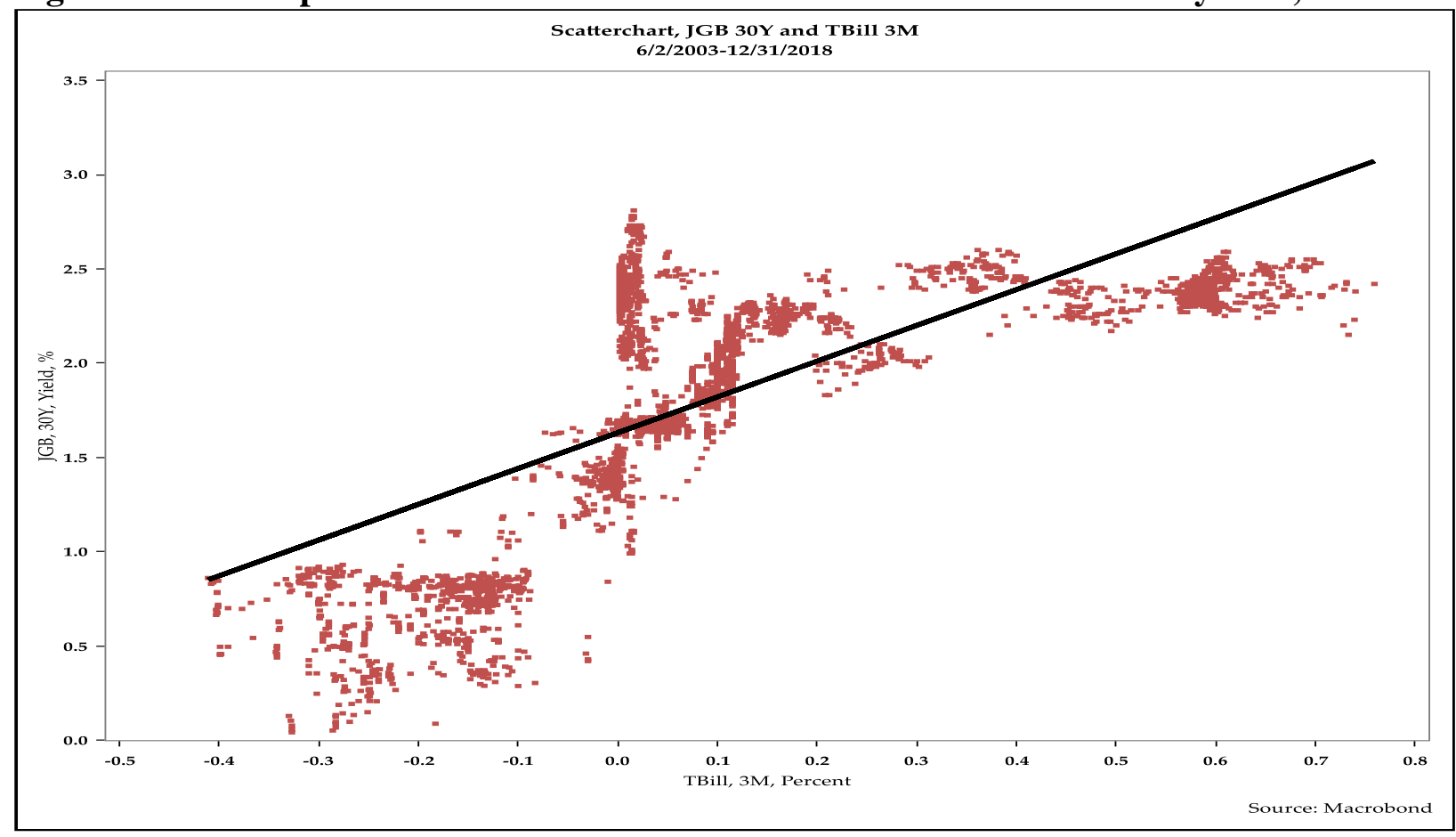

Figure 24: Scatterplot of Year-Over-Year Percentage Point Changes in the Yields of 30Year JGBs and 3-Month Treasury Bills, 2004-18

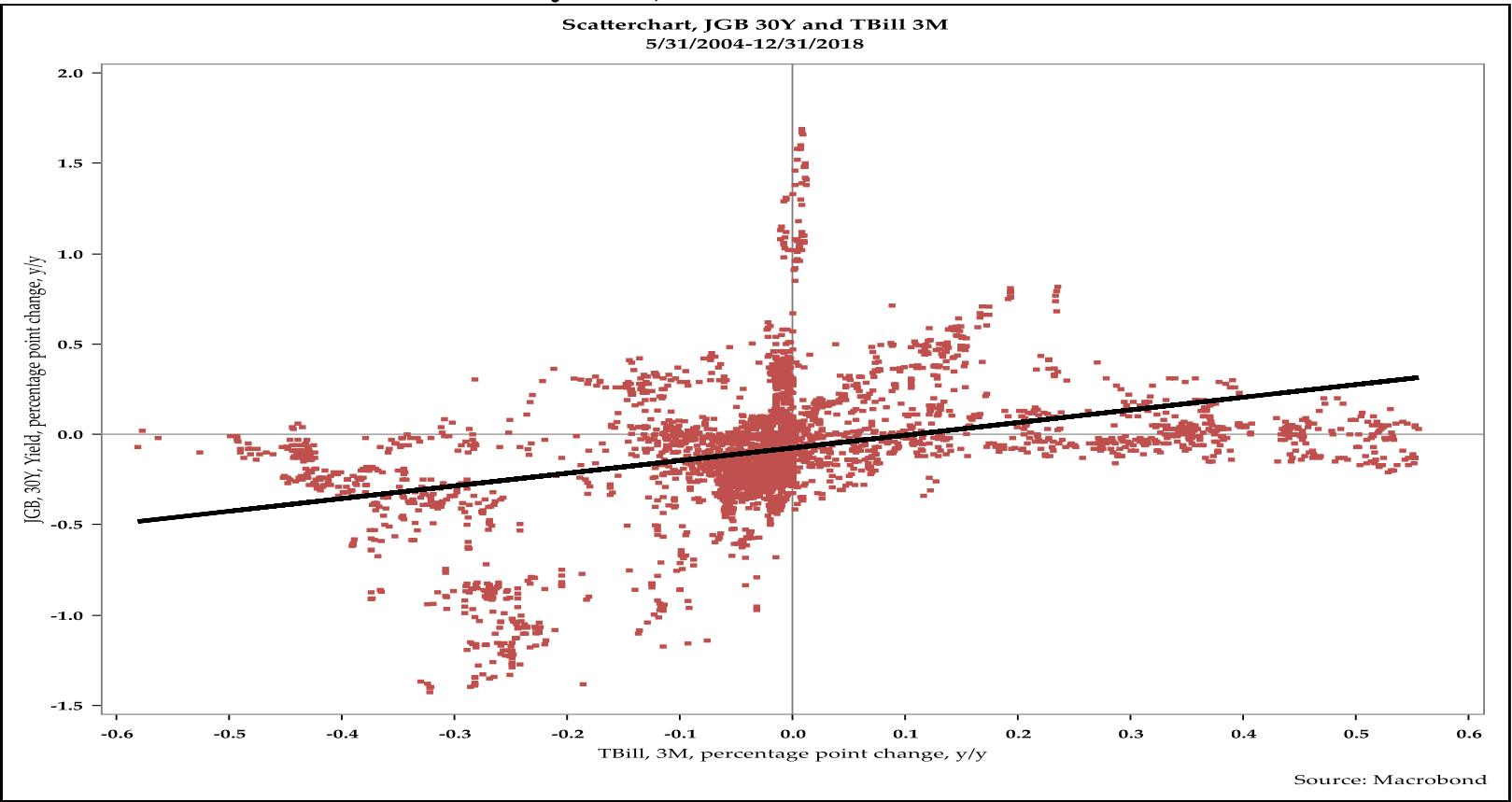




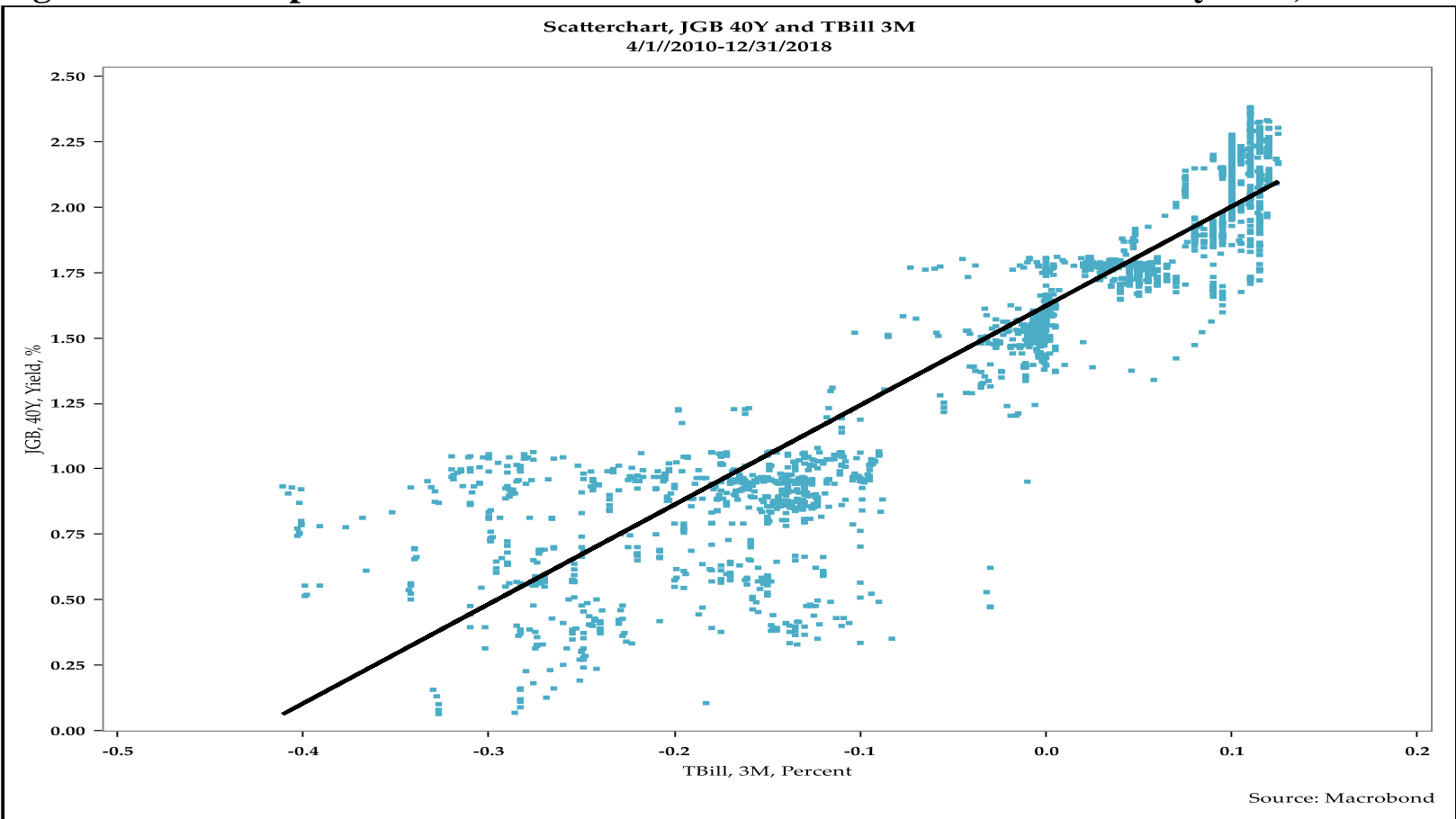

Figure 26: Scatterplot of Year-Over-Year Percentage Point Changes in the Yields of 40Year JGBs and 3-Month Treasury Bills, 2011-18

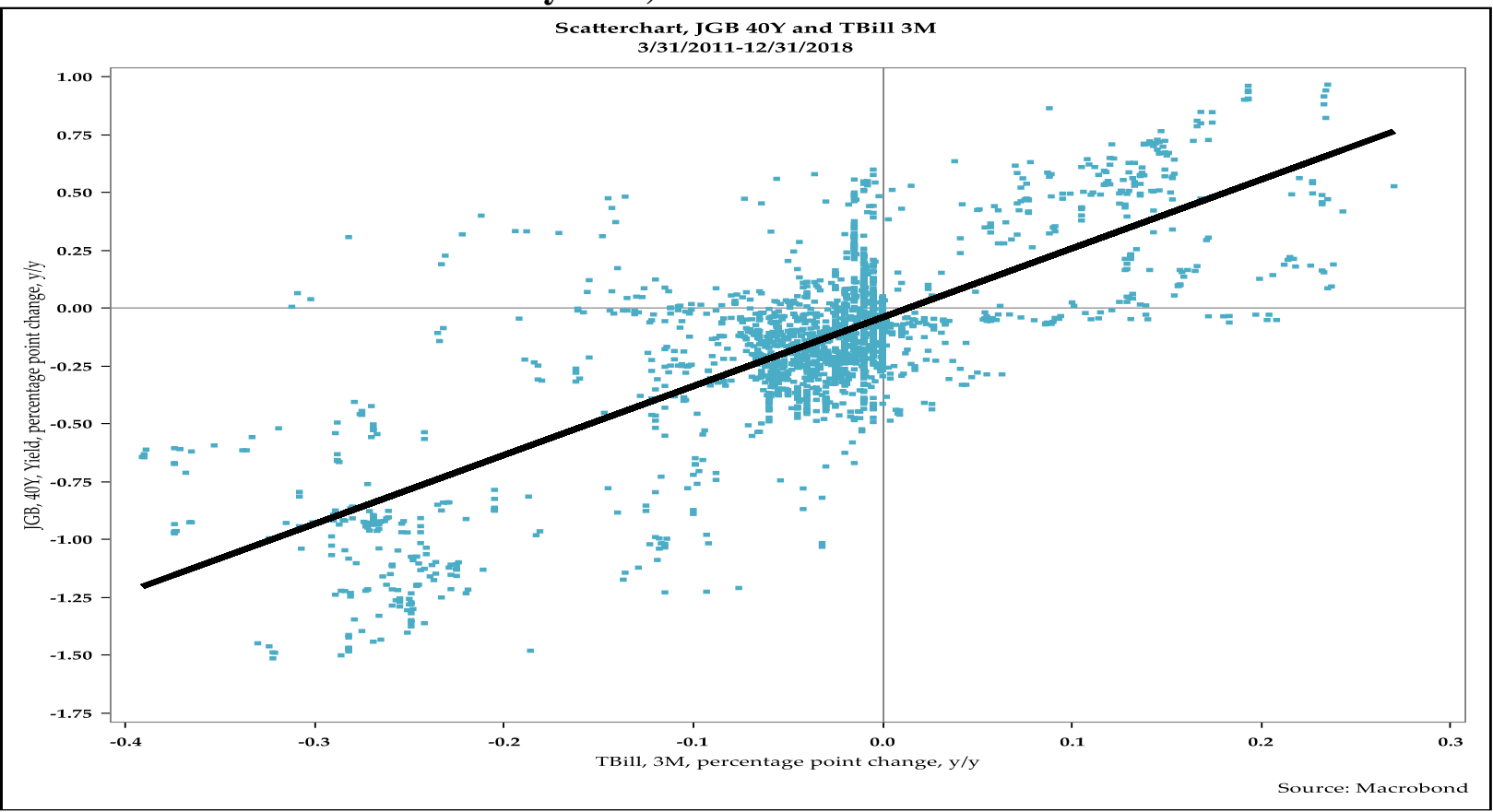


Figure 27: The Evolution of Year-Over-Year Percentage Point Changes in the Yields of JGBs of Selected Tenors and Year-Over-Year Percentage Changes in the Nikkei Index, 2000-18

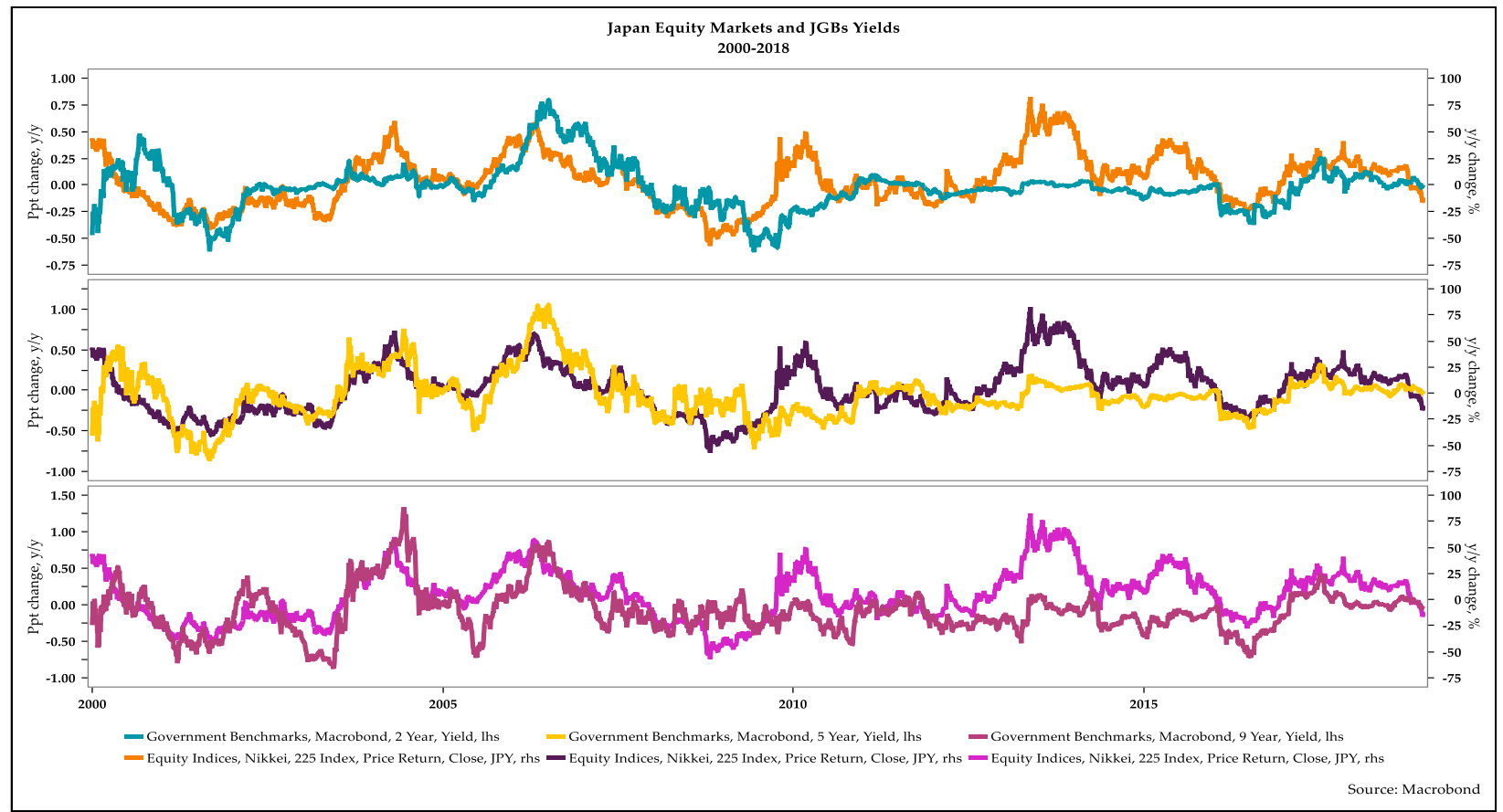

Figure 28: The Evolution of the Yields of 10-Year JGBs and the Exchange Rate, 2000-18

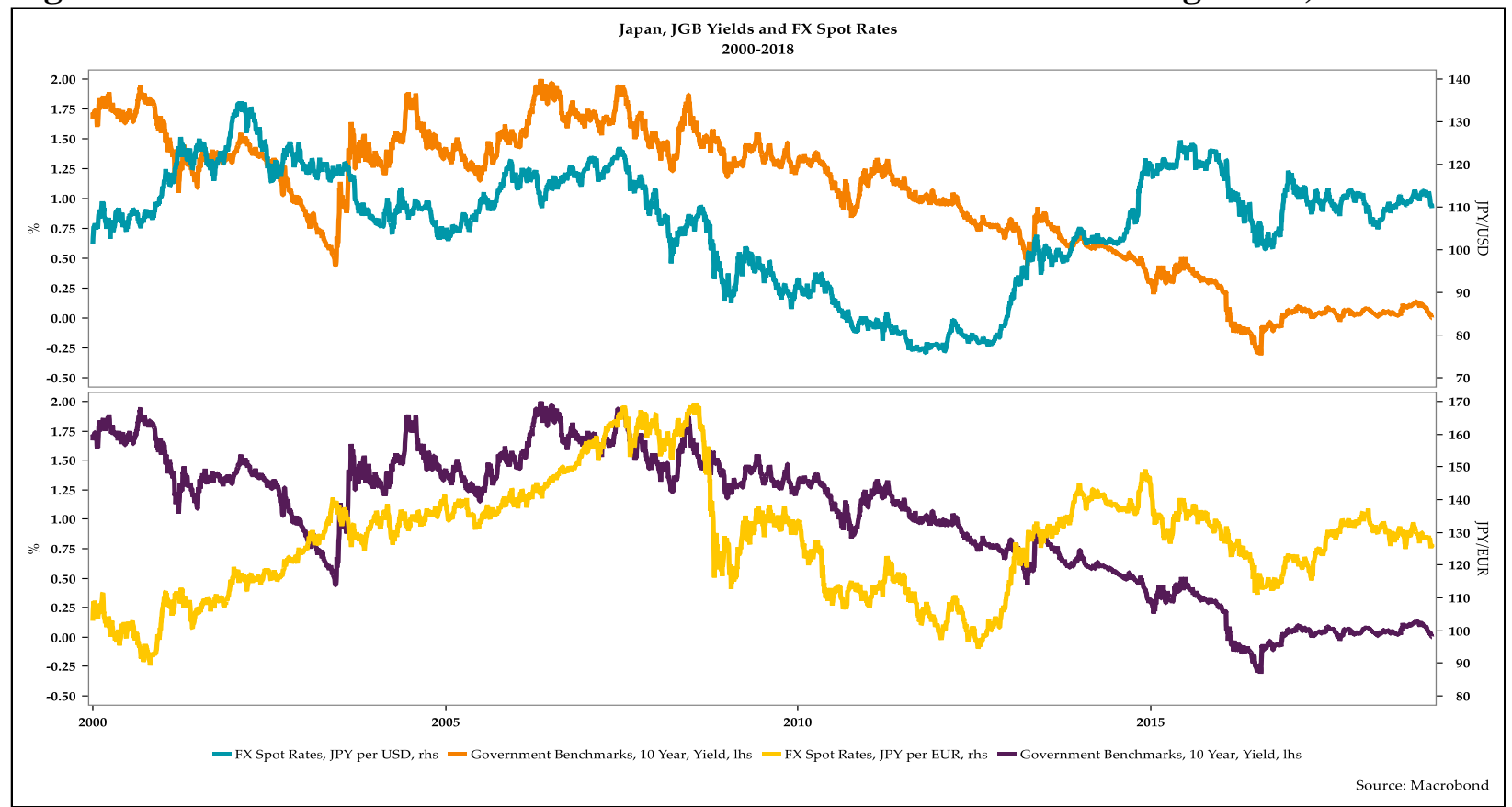




\section{DATA DESCRIPTION AND UNIT ROOT TESTS}

This paper uses time series macroeconomic and financial data. Daily data (five-day week) on key financial variables, such as long-term interest rates, short-term interest rates, equity indexes, the exchange rate, indexes of oil and commodity prices, and other variables are deployed.

Long-term interest rates are gathered from the nominal yields of JGBs of 2-, 3-, 4-, 5-, 7-, 8-, 9-, 10-, 15-, 20-, 30-, and 40-year tenors, as calibrated by Japan's Ministry of Finance.

Short-term interest rates are obtained from the discount rate on Japanese government Treasury bills of 1-, 3-, 6-, 9-, and 12-month tenors.

Exchange rates data are based on the spot rates for the Japanese yen per US dollar and the Japanese yen per euro at the close of each business day.

Energy and commodity prices are obtained from crude oil spot prices and the Bloomberg commodity index. These are proxies for daily measures of inflationary pressure and inflationary expectations, since daily measures of the consumer price index or core consumer price index are not available.

Table 1 provides a summary of the data. The first column shows the label for each variable. The second column lists the variables' description and the time range for the data. The third column displays the frequency of the data. The last column provides both the primary and secondary sources for the data.

Most of the data covers January 2000 to December 2018. The daily frequency of data means that most variables are derived from more than 4,500 observations. Such a large number of observations enables the application of a wide range of models to test the hypothesis and detect structural breaks. It also gives a high degree of freedom to the modeling framework and to robustness checks that are conducted. 
Table 1: Summary of the Data

\begin{tabular}{|c|c|c|c|}
\hline Variables & Data description; date range & Frequency & Sources \\
\hline \multicolumn{4}{|c|}{ Short-term interest rates } \\
\hline TB1M & $\begin{array}{l}\text { Japanese government treasury bill, } \\
\text { 3-month, yield, } \% ; 4 / 1 / 10-12 / 31 / 18\end{array}$ & Daily & Macrobond \\
\hline TB3M & $\begin{array}{l}\text { Japanese government treasury bill, } \\
\text { 3-month, yield, } \% ; 8 / 16 / 01-12 / 31 / 18\end{array}$ & Daily & Macrobond \\
\hline TB6M & $\begin{array}{l}\text { Japanese government treasury bill, } \\
\text { 6-month, yield, } \% ; 8 / 16 / 01-12 / 31 / 18\end{array}$ & Daily & Macrobond \\
\hline TB9M & $\begin{array}{l}\text { Japanese government treasury bill, } \\
\text { 9-month, yield, } \% ; 8 / 16 / 01-12 / 31 / 18\end{array}$ & Daily & Macrobond \\
\hline TB12M & $\begin{array}{l}\text { Japanese government treasury bill, } \\
\text { 12-month, yield, } \% ; 1 / 3 / 00-12 / 31 / 18\end{array}$ & Daily & Macrobond \\
\hline \multicolumn{4}{|c|}{ Japanese Government Bond (JGB) yields } \\
\hline JGB2Y & $\begin{array}{l}\text { Japanese government bond, } \\
\text { 2-year, yield, } \% ; 1 / 3 / 00-12 / 31 / 18\end{array}$ & Daily & $\begin{array}{l}\text { Ministry of Finance; } \\
\text { Macrobond }\end{array}$ \\
\hline JGB3Y & $\begin{array}{l}\text { Japanese government bond, } \\
\text { 3-year, yield, } \% ; 1 / 3 / 00-12 / 31 / 18\end{array}$ & Daily & $\begin{array}{l}\text { Ministry of Finance; } \\
\text { Macrobond }\end{array}$ \\
\hline JGB4Y & $\begin{array}{l}\text { Japanese government bond, } \\
\text { 4-year, yield, } \% ; 1 / 3 / 00-12 / 31 / 18\end{array}$ & Daily & $\begin{array}{l}\text { Ministry of Finance; } \\
\text { Macrobond }\end{array}$ \\
\hline JGB5Y & $\begin{array}{l}\text { Japanese government bond, } \\
\text { 5-year, yield, \%; 1/3/00-12/31/18 }\end{array}$ & Daily & $\begin{array}{l}\text { Ministry of Finance; } \\
\text { Macrobond }\end{array}$ \\
\hline JGB6Y & $\begin{array}{l}\text { Japanese government bond, } \\
\text { 6-year, yield, \%; 1/3/00-12/31/18 }\end{array}$ & Daily & $\begin{array}{l}\text { Ministry of Finance; } \\
\text { Macrobond }\end{array}$ \\
\hline JGB7Y & $\begin{array}{l}\text { Japanese government bond, } \\
\text { 7-year, yield, } \% ; 1 / 3 / 00-12 / 31 / 18\end{array}$ & Daily & $\begin{array}{l}\text { Ministry of Finance; } \\
\text { Macrobond }\end{array}$ \\
\hline JGB8Y & $\begin{array}{l}\text { Japanese government bond, } \\
\text { 8-year, yield, } \% ; 1 / 3 / 00-12 / 31 / 18\end{array}$ & Daily & $\begin{array}{l}\text { Ministry of Finance; } \\
\text { Macrobond }\end{array}$ \\
\hline JGB9Y & $\begin{array}{l}\text { Japanese government bond, } \\
\text { 9-year, yield, \%; 1/3/00-12/31/18 }\end{array}$ & Daily & $\begin{array}{l}\text { Ministry of Finance; } \\
\text { Macrobond }\end{array}$ \\
\hline JGB10Y & $\begin{array}{l}\text { Japanese government bond, } \\
10 \text {-year, yield, } \% ; 1 / 3 / 00-12 / 31 / 18\end{array}$ & Daily & $\begin{array}{l}\text { Ministry of Finance; } \\
\text { Macrobond }\end{array}$ \\
\hline JGB15Y & $\begin{array}{l}\text { Japanese government bond, } \\
15 \text {-year, yield, } \% ; 4 / 1 / 10-12 / 31 / 18\end{array}$ & Daily & $\begin{array}{l}\text { Ministry of Finance; } \\
\text { Macrobond }\end{array}$ \\
\hline JGB30Y & $\begin{array}{l}\text { Japanese government bond, } \\
30 \text {-year, yield, } \% ; 6 / 2 / 03-12 / 31 / 18\end{array}$ & Daily & $\begin{array}{l}\text { Ministry of Finance; } \\
\text { Macrobond }\end{array}$ \\
\hline JGB40Y & $\begin{array}{l}\text { Japanese government bond, } \\
\text { 40-year, yield, } \% ; 4 / 1 / 10-12 / 31 / 18\end{array}$ & Daily & $\begin{array}{l}\text { Ministry of Finance; } \\
\text { Macrobond }\end{array}$ \\
\hline \multicolumn{4}{|c|}{ Equity Index } \\
\hline NIKKEI & $\begin{array}{l}\text { Equity index, Nikkei, } 225 \text { index, price } \\
\text { return, close, JPY; } 1 / 3 / 00-12 / 31 / 18\end{array}$ & Daily & Macrobond \\
\hline TOPIX & $\begin{array}{l}\text { Equity index, TOPIX, total, index, price } \\
\text { return, close, JPY; } 1 / 3 / 00-12 / 31 / 18\end{array}$ & Daily & $\begin{array}{l}\text { Japanese Statistics } \\
\text { Bureau; Macrobond }\end{array}$ \\
\hline \multicolumn{4}{|c|}{ Exchange Rate } \\
\hline JPYUSD & $\begin{array}{l}\text { Spot rate, Japanese yen per U.S. dollar, } \\
¥ / \$ ; 1 / 3 / 00-12 / 31 / 18\end{array}$ & Daily & Macrobond \\
\hline JPYEUR & $\begin{array}{l}\text { Spot rate, Japanese yen per euro, } ¥ / € \text {; } \\
1 / 3 / 00-12 / 31 / 18\end{array}$ & Daily & Macrobond \\
\hline
\end{tabular}




\begin{tabular}{|l|l|l|l|}
\hline Variables & Data description; date range & Frequency & Sources \\
\hline Commodity Prices & $\begin{array}{l}\text { Crude oil, brent, spot, freight on board, } \\
\text { North Sea, Intercontinental exchange, } \\
\text { close, USD; } 1 / 3 / 00-12 / 31 / 18\end{array}$ & Daily & Macrobond \\
\hline INFL & $\begin{array}{l}\text { Bloomberg, commodity index, price } \\
\text { return, close, JPY; } 1 / 3 / 00-12 / 31 / 18\end{array}$ & Daily & Macrobond \\
\hline
\end{tabular}

\section{EMPIRICAL MODELS AND INTERPRETATION OF FINDINGS}

\subsection{Model Specification}

The vector error correction model (VECM), as developed by Johansen (1988, 1991, and 1995), is appropriate for the present analysis since the variables in the model are cointegrated, as will be shown in the next subsection. ${ }^{1}$ Johansen's model has cointegration relations built into the specification such that it restricts the long-run behavior of the endogenous variables from converging to their cointegrating relationships while allowing for short-run adjustment dynamics. The dynamic relations between the variables - the short-term interest rates, the longterm interest rate, (commodity) inflation, equity index and exchange rate-are examined in the VECM following Johansen's procedure.

Consider a vector autoregression (VAR) model, adapted to the VECM representation, as given below:

$$
\Delta Z_{t}=\Gamma_{1} \Delta Z_{t-1}+\ldots+\Gamma_{p-t} \Delta Z_{t-p+1}+\alpha \beta^{\prime} Z_{t-p}+v+e_{t} \ldots
$$

where:

$$
\begin{aligned}
& Z_{t}=\text { (long-term interest rate, short-term interest rate)' (model 1). }^{\prime} \\
& Z_{t}=\text { (long-term interest rate, short-term interest rate, inflation)' (model 2). } \\
& Z_{t}=\text { (long-term interest rate, short-term interest rate, inflation, equity index)' (model 3). }
\end{aligned}
$$

\footnotetext{
${ }^{1}$ The structure of empirical section is similar to that of Akram and Li (2018 and 2019b). However, a key difference is that this paper uses daily data.
} 
$Z_{t}=$ (long-term interest rate, short-term interest rate, inflation, equity index, exchange rate)' (model 4).

Here, $\alpha \beta^{\prime} Y_{t-p}$ represents the error-correction components. $\alpha$ is an $(n \times r)$ matrix that explains long-run disequilibrium and $\beta$ is an $(n \times r)$ matrix of cointegrating vectors that explains the longrun relationships. $\Gamma_{j} \Delta \mathrm{Z}_{t-j}$ is the vector autoregressive component in first difference. $\Gamma_{\mathrm{j}}$ is an $(n x$ n) matrix that stands for the short-term adjustment coefficients among variables with $p$ - 1 number of lags. $v$ is a deterministic shift vector, while model residuals $e_{t}$ are white noise.

\subsection{Model Estimation}

The model estimation consists of several steps. First, various tests for a unit root in each series are conducted. Second, tests for the number of cointegrating vectors in the system are undertaken, given that one cannot reject the null hypothesis of nonstationary variables. Third, structural breaks are identified using the appropriate statistical tests. Fourth, the model is estimated in the framework of a multivariate VECM.

\subsubsection{Unit Root Tests}

Unit root tests are performed to determine the univariate properties of the following variables: nominal yields of Japanese Treasury bills of 3-month tenor; yields of JGBs of 5-year tenors; inflation (using commodity price indexes); NIKKEI equity index; TOPIX equity index; Japanese yen to US dollar exchange rate; and Japanese yen to euro exchange rate. ${ }^{2}$

The results are presented in tables 2.1 and 2.2. It is evident from table 2.1 that the calculated augmented Dickey-Fuller (ADF) (Dickey and Fuller 1979, 1981) statistics are less than their critical values in all cases. The only exception is the rate of commodity inflation. For inflation, the null hypothesis is rejected at 5 percent significance, but not at 1 percent significance. Similarly, based on the Phillips-Perron (PP) (Phillips and Perron 1988) tests for inflation, the

\footnotetext{
2 The results of the unit root tests on the nominal yields of JGBs of other tenors (2-, 3-, 6-, 7-, 8, 10-, 15-, 20-, 25-, 30-, 40- years) are consistent with the nominal yields of JGBs of 5- and 9-year tenors. Results are provided in appendix tables A1 and A2.
} 
null hypothesis is rejected at a 10 percent level of significance, but the null hypothesis cannot be rejected at the 5 percent and 1 percent levels of significance. This suggests that inflation is not stationary. Table 2.2, which shows the results of the unit root test for the first differences of the series, show that for most series the null hypothesis that there is a unit root is significantly rejected in first differences. Thus, it can be concluded that all the series, including inflation, are integrated of the first order, I(1) series. 
Table 2.1: Unit Root Tests (Level)

\begin{tabular}{|c|c|c|c|c|c|}
\hline Variable & & Tests & Statistic & P-value & Obs. \\
\hline \multirow{6}{*}{ JGB5Y } & \multirow{2}{*}{ Trend } & $\mathrm{ADF}$ & -2.202 & 0.489 & 4955 \\
\hline & & PP & -2.146 & 0.520 & 4955 \\
\hline & \multirow{2}{*}{ No trend } & $\mathrm{ADF}$ & -1.548 & 0.510 & 4955 \\
\hline & & $\mathrm{PP}$ & -1.497 & 0.535 & 4955 \\
\hline & \multirow{2}{*}{ No trend, no constant } & ADF & -1.567 & & 4955 \\
\hline & & PP & -1.543 & & 4955 \\
\hline \multirow{6}{*}{ JGB9Y } & \multirow{2}{*}{ Trend } & $\mathrm{ADF}$ & -2.809 & 0.194 & 4955 \\
\hline & & $\mathrm{PP}$ & -2.801 & 0.197 & 4955 \\
\hline & \multirow{2}{*}{ No trend } & $\mathrm{ADF}$ & -1.467 & 0.546 & 4955 \\
\hline & & $\mathrm{PP}$ & -1.461 & 0.553 & 4955 \\
\hline & \multirow{2}{*}{ No trend, no constant } & $\mathrm{ADF}$ & -1.539 & & 4955 \\
\hline & & PP & -1.536 & & 4955 \\
\hline \multirow{6}{*}{ TB3M } & \multirow{2}{*}{ Trend } & $\mathrm{ADF}$ & -2.360 & 0.401 & 4532 \\
\hline & & PP & -1.922 & 0.643 & 4532 \\
\hline & \multirow{2}{*}{ No trend } & $\mathrm{ADF}$ & -1.947 & 0.310 & 4532 \\
\hline & & $\mathrm{PP}$ & -1.485 & 0.541 & 4532 \\
\hline & \multirow{2}{*}{ No trend, no constant } & $\mathrm{ADF}$ & -1.890 & & 4532 \\
\hline & & PP & -1.475 & & 4532 \\
\hline \multirow{6}{*}{ TOPIX } & \multirow{2}{*}{ Trend } & $\mathrm{ADF}$ & -2.276 & 0.447 & 4955 \\
\hline & & PP & -2.237 & 0.469 & 4955 \\
\hline & \multirow{2}{*}{ No trend } & ADF & -1.987 & 0.292 & 4955 \\
\hline & & $\mathrm{PP}$ & -1.942 & 0.312 & 4955 \\
\hline & \multirow{2}{*}{ No trend, no constant } & $\mathrm{ADF}$ & -0.696 & & 4955 \\
\hline & & PP & -0.690 & & 4955 \\
\hline \multirow{6}{*}{ NIKKEI } & \multirow{2}{*}{ Trend } & $\mathrm{ADF}$ & -2.494 & 0.331 & 4955 \\
\hline & & PP & -2.441 & 0.358 & 4955 \\
\hline & \multirow{2}{*}{ No trend } & $\mathrm{ADF}$ & -1.515 & 0.526 & 4955 \\
\hline & & $\mathrm{PP}$ & -1.439 & 0.564 & 4955 \\
\hline & \multirow{2}{*}{ No trend, no constant } & $\mathrm{ADF}$ & -0.360 & & 4955 \\
\hline & & $\mathrm{PP}$ & -0.333 & & 4955 \\
\hline \multirow{6}{*}{ JPYUSD } & \multirow{2}{*}{ Trend } & $\mathrm{ADF}$ & -1.831 & 0.689 & 4955 \\
\hline & & PP & -1.782 & 0.713 & 4955 \\
\hline & No trend & $\mathrm{ADF}$ & -1.739 & 0.411 & 4955 \\
\hline & गण पाiि & PP & -1.690 & 0.436 & 4955 \\
\hline & No trend no constant & $\mathrm{ADF}$ & -0.043 & & 4955 \\
\hline & No trena, no constant & $\mathrm{PP}$ & -0.030 & & 4955 \\
\hline & Trend & $\mathrm{ADF}$ & -2.214 & 0.522 & 4955 \\
\hline & Irend & PP & -2.136 & 0.526 & 4955 \\
\hline & & ADF & -2.209 & 0.203 & 4955 \\
\hline JPYEUR & No trend & PP & -2.203 & 0.205 & 4955 \\
\hline & No trend no conctont & $\mathrm{ADF}$ & 0.056 & & 4955 \\
\hline & No trend, no constant & PP & 0.060 & & 4955 \\
\hline & Thond 120 & ADF & -3.716 & 0.021 & 4695 \\
\hline & Irend & PP & -3.404 & 0.051 & 4695 \\
\hline INE & No trond 1 & ADF & -3.02 & 0.033 & 4695 \\
\hline INF & No trend & PP & -2.725 & 0.070 & 4695 \\
\hline & Ne trend no conctont & ADF & -2.712 & & 4695 \\
\hline & No trend, no constant & PP & -2.475 & & 4695 \\
\hline
\end{tabular}


Table 2.2: Unit Root Tests (First Difference)

\begin{tabular}{|c|c|c|c|c|c|}
\hline Variable & & Tests & Statistic & P-value & Obs. \\
\hline \multirow{6}{*}{$\triangle$ JGB5Y } & \multirow{2}{*}{ Trend } & $\mathrm{ADF}$ & -68.112 & 0.000 & 4954 \\
\hline & & PP & -68.108 & 0.000 & 4954 \\
\hline & \multirow{2}{*}{ No trend } & $\mathrm{ADF}$ & -68.119 & 0.000 & 4954 \\
\hline & & PP & -68.115 & 0.000 & 4954 \\
\hline & \multirow{2}{*}{ No trend, no constant } & $\mathrm{ADF}$ & -68.119 & 0.000 & 4954 \\
\hline & & $\mathrm{PP}$ & -68.114 & 0.000 & 4954 \\
\hline \multirow{6}{*}{$\triangle$ JGB9Y } & \multirow{2}{*}{ Trend } & $\mathrm{ADF}$ & -71.508 & 0.000 & 4954 \\
\hline & & $\mathrm{PP}$ & -71.504 & 0.000 & 4954 \\
\hline & \multirow{2}{*}{ No trend } & $\mathrm{ADF}$ & -71.515 & 0.000 & 4954 \\
\hline & & $\mathrm{PP}$ & -71.511 & 0.000 & 4954 \\
\hline & \multirow{2}{*}{ No trend, no constant } & $\mathrm{ADF}$ & -71.510 & 0.000 & 4954 \\
\hline & & PP & -71.506 & 0.000 & 4954 \\
\hline \multirow{6}{*}{$\Delta \mathrm{TB3M}$} & \multirow{2}{*}{ Trend } & $\mathrm{ADF}$ & -75.327 & 0.000 & 4531 \\
\hline & & PP & -77.249 & 0.000 & 4531 \\
\hline & \multirow{2}{*}{ No trend } & $\mathrm{ADF}$ & -75.330 & 0.000 & 4531 \\
\hline & & PP & -77.240 & 0.000 & 4531 \\
\hline & \multirow{2}{*}{ No trend, no constant } & $\mathrm{ADF}$ & -75.337 & 0.000 & 4531 \\
\hline & & $\mathrm{PP}$ & -77.247 & 0.000 & 4531 \\
\hline \multirow{6}{*}{$\triangle$ TOPIX } & \multirow{2}{*}{ Trend } & $\mathrm{ADF}$ & -68.111 & 0.000 & 4954 \\
\hline & & PP & -68.106 & 0.000 & 4954 \\
\hline & \multirow{2}{*}{ No trend } & $\mathrm{ADF}$ & -68.101 & 0.000 & 4954 \\
\hline & & PP & -68.093 & 0.000 & 4954 \\
\hline & \multirow{2}{*}{ No trend, no constant } & $\mathrm{ADF}$ & -68.107 & 0.000 & 4954 \\
\hline & & PP & -68.100 & 0.000 & 4954 \\
\hline \multirow{6}{*}{$\Delta$ NIKKEI } & \multirow{2}{*}{ Trend } & $\mathrm{ADF}$ & -72.675 & 0.000 & 4954 \\
\hline & & PP & -72.738 & 0.000 & 4954 \\
\hline & \multirow{2}{*}{ No trend } & $\mathrm{ADF}$ & -72.650 & 0.000 & 4954 \\
\hline & & $\mathrm{PP}$ & -72.707 & 0.000 & 4954 \\
\hline & \multirow{2}{*}{ No trend, no constant } & $\mathrm{ADF}$ & -72.657 & 0.000 & 4954 \\
\hline & & PP & -72.714 & 0.000 & 4954 \\
\hline \multirow{6}{*}{$\triangle \mathbf{J P Y U S D}$} & \multirow{2}{*}{ Trend } & $\mathrm{ADF}$ & -71.570 & 0.000 & 4954 \\
\hline & & $\mathrm{PP}$ & -71.605 & 0.000 & 4954 \\
\hline & No trend & $\mathrm{ADF}$ & -71.577 & 0.000 & 4954 \\
\hline & No trend & PP & -71.612 & 0.000 & 4954 \\
\hline & Nh trond no bonetont & $\mathrm{ADF}$ & -71.584 & 0.000 & 4954 \\
\hline & No trend, no constant & $\mathrm{PP}$ & -71.619 & 0.000 & 4954 \\
\hline & Trend & $\mathrm{ADF}$ & -69.654 & 0.000 & 4954 \\
\hline & Irend & $\mathrm{PP}$ & -69.654 & 0.000 & 4954 \\
\hline$\triangle$ IPVEUP & No trend & $\mathrm{ADF}$ & -69.656 & 0.000 & 4954 \\
\hline$\triangle$ JPYEUK & No trena & PP & -69.655 & 0.000 & 4954 \\
\hline & No trond no & ADF & -69.661 & 0.000 & 4954 \\
\hline & No trend, no constant & PP & -69.661 & 0.000 & 4954 \\
\hline & $T$ & $\mathrm{ADF}$ & -70.174 & 0.000 & 4694 \\
\hline & Irend & PP & -70.543 & 0.000 & 4694 \\
\hline AINT & No twond & ADF & -70.18 & 0.000 & 4694 \\
\hline$\triangle \mathrm{IINF}$ & No trend & PP & -70.548 & 0.000 & 4694 \\
\hline & & $\mathrm{ADF}$ & -70.186 & 0.000 & 4694 \\
\hline & No trend, no constant & PP & -70.553 & 0.000 & 4694 \\
\hline
\end{tabular}


Notes: The ADF and PP test critical values respectively are at 1 percent: $-3.960,5$ percent: $-3.410,10$ percent: 3.120 (Trend); 1 percent: $-3.430,5$ percent: $-2.860,10$ percent: -2.570 (No trend); 1 percent: -2.580 , 5 percent: 1.950, 10 percent: -1.620 (No trend, no constant). PP test, $\mathrm{ADF}$ test $\left(\mathrm{H}_{0}\right.$ : series has a unit root).

\subsubsection{Cointegration Test}

Johansen and Juselius's (1990) cointegration method is initially deployed to determine whether there is a stable, long-run relationship between the short-term interest rate, inflation, the equity index, the exchange rate, and the long-term interest rate.

To analyze the cointegration relationships between the variables, 14 VAR models are defined as follows:

- $\quad(\mathrm{JGB} 5 \mathrm{Y}, \mathrm{TB} 3 \mathrm{M})$

- (JGB5Y, TB3M, INF)

- (JGB5Y, TB3M, TOPIX)

- (JGB5Y, TB3M, NIKKEI)

- (JGB5Y, TB3M, JPYUSD)

- (JGB5Y, TB3M, JPYEUR)

- (JGB5Y, TB3M, TOPIX, INF)

- (JGB5Y, TB3M, NIKKEI, INF)

- (JGB5Y, TB3M, JPYUSD, INF)

- (JGB5Y, TB3M, JPYEUR, INF)

- (JGB5Y, TB3M, TOPIX, JPYUSD, INF)

- (JGB5Y, TB3M, TOPIX, JPYEUR, INF)

- (JGB5Y, TB3M, NIKKEI, JPYUSD, INF)

- (JGB5Y, TB3M, NIKKEI, JPYEUR, INF)

Table 3 presents test statistics for determining whether there is a long-run relationship in any of those models. The results, based on the above-mentioned VARs, are generally found to be sensitive to the lag length used and the ordering of the variables. Thus, lag lengths were chosen by the Akaike information criterion (AIC), the Schwarz-Bayesian information criterion (SBIC), and the Hannan and Quinn information criterion (HQIC) before determining the number of cointegrating vectors. 
The Johansen cointegration test compares both trace and likelihood eigenvalue statistics to their critical values. The null hypothesis is that there is no significant difference between log likelihood of the unconstrained model with the cointegrating equations and log likelihood of the constrained model that does not include the cointegrating equations. The test starts from the model with no cointegration and then proceeds to the model with one, two, or three cointegrating vectors, until it finds the first model in which the null hypothesis of no cointegrating vector cannot be rejected. For instance, in the case of (JGB5Y, TB3M, TOPIX, INF), the trace statistics at $r=0$ of 71.3951 exceed its critical value of 54.46. This means that the null hypothesis of no cointegrating equations can be rejected. The trace statistics at $r=1$ of 28.6629 is less than the critical value of 35.65 at the 1 percent level of significance; hence, the null hypothesis that there is one cointegrating vector in the system cannot be rejected. The maximum eigenvalue test provides more conclusive evidence regarding the exact number of cointegrating vectors in the system. According to table 3 and without any further analysis, these findings suggest that there is at least one cointegrating equation in most of those models, though not in all of them. However, since standard cointegration techniques are biased toward accepting the null hypothesis of no cointegration in the presence of structural breaks, it is prudent to further explore potential structural breaks with the Gregory and Hansen (1996) cointegration test.

Table 3: Multivariate Cointegration Tests

\begin{tabular}{|c|c|c|c|c|c|}
\hline \multicolumn{3}{|c|}{ Trace Test } & \multicolumn{3}{|c|}{ Maximum Eigenvalue Test } \\
\hline Null hypo. & Test statistic & $1 \%$ critical value & Null hypo. & Test statistic & $1 \%$ critical value \\
\hline \multicolumn{6}{|c|}{ (JGB5Y, TB3M); AIC lag-order=5 } \\
\hline $\mathrm{r}=0$ & 22.7264 & 20.04 & $r=0$ & 20.7575 & 18.63 \\
\hline $\mathrm{r \# 1}$ & $1.9689^{*}$ & 6.65 & $\mathrm{r} \# 1$ & 1.9689 & 6.65 \\
\hline \multicolumn{6}{|c|}{ (JGB5Y, TB3M, INF); AIC lag-order=5 } \\
\hline $\mathrm{r}=0$ & 61.4247 & 35.65 & $\mathrm{r}=0$ & 40.5942 & 25.52 \\
\hline $\mathrm{r} \# 1$ & 20.8305 & 20.04 & $\mathrm{r} \# 1$ & 18.5835 & 18.63 \\
\hline $\mathrm{r} \# 2$ & $2.2470^{*}$ & 6.65 & $\mathrm{r} \# 2$ & 2.247 & 6.65 \\
\hline \multicolumn{6}{|c|}{ (JGB5Y, TB3M, TOPIX); AIC lag-order=6 } \\
\hline $\mathrm{r}=0$ & $30.4914 *$ & 35.65 & $\mathrm{r}=0$ & 22.036 & 25.52 \\
\hline $\mathrm{r} \# 1$ & 8.4554 & 20.04 & $\mathrm{r} \# 1$ & 7.093 & 18.63 \\
\hline $\mathrm{r} \# 2$ & 1.3624 & 6.65 & $\mathrm{r} \# 2$ & 1.3624 & 6.65 \\
\hline \multicolumn{6}{|c|}{ (JGB5Y, TB3M, NIKKEI); AIC lag-order=6 } \\
\hline $\mathrm{r}=0$ & $29.9150 *$ & 35.65 & $\mathrm{r}=0$ & 22.5956 & 25.52 \\
\hline $\mathrm{r} \# 1$ & 7.3194 & 20.04 & $\mathrm{r} \# 1$ & 6.8772 & 18.63 \\
\hline $\mathrm{r} \# 2$ & 0.4422 & 6.65 & $\mathrm{r} \# 2$ & 0.4422 & 6.65 \\
\hline \multicolumn{6}{|c|}{ (JGB5Y, TB3M, JPYUSD); AIC lag-order=6 } \\
\hline $\mathrm{r}=0$ & $26.4989 *$ & 35.65 & $\mathrm{r}=0$ & 19.8338 & 25.52 \\
\hline r\#1 & 6.6652 & 20.04 & $\mathrm{r} \# 1$ & 4.6892 & 18.63 \\
\hline $\mathrm{r} \# 2$ & 1.976 & 6.65 & $\mathrm{r} \# 2$ & 1.976 & 6.65 \\
\hline
\end{tabular}




\begin{tabular}{|c|c|c|c|c|c|}
\hline \multicolumn{6}{|c|}{ (JGB5Y, TB3M, JPYEUR); AIC lag-order=6 } \\
\hline $\mathrm{r}=0$ & $31.8472 *$ & 35.65 & $\mathrm{r}=0$ & 22.4728 & 25.52 \\
\hline $\mathrm{r} \# 1$ & 9.3744 & 20.04 & $\mathrm{r} \# 1$ & 7.3563 & 18.63 \\
\hline $\mathrm{r} \# 2$ & 2.0181 & 6.65 & $\mathrm{r} \# 2$ & 2.0181 & 6.65 \\
\hline \multicolumn{6}{|c|}{ (JGB5Y, TB3M, TOPIX, INF); AIC lag-order=5 } \\
\hline $\mathrm{r}=0$ & 71.3951 & 54.46 & $\mathrm{r}=0$ & 42.7323 & 32.24 \\
\hline $\mathrm{r} \# 1$ & $28.6629 *$ & 35.65 & $\mathrm{r} \# 1$ & 20.7762 & 25.52 \\
\hline $\mathrm{r} \# 2$ & 7.8867 & 20.04 & $\mathrm{r} \# 2$ & 7.0726 & 18.63 \\
\hline $\mathrm{r} \# 3$ & 0.8141 & 6.65 & $\mathrm{r} \# 3$ & 0.8141 & 6.65 \\
\hline \multicolumn{6}{|c|}{ (JGB5Y, TB3M, NIKKEI, INF); AIC lag-order=5 } \\
\hline $\mathrm{r}=0$ & 70.0948 & 54.46 & $\mathrm{r}=0$ & 41.198 & 32.24 \\
\hline $\mathrm{r} \# 1$ & $28.8968^{*}$ & 35.65 & $\mathrm{r} \# 1$ & 21.6919 & 25.52 \\
\hline $\mathrm{r} \# 2$ & 7.2049 & 20.04 & $\mathrm{r} \# 2$ & 7.0435 & 18.63 \\
\hline $\mathrm{r} \# 3$ & 0.1614 & 6.65 & $\mathrm{r} \# 3$ & 0.1614 & 6.65 \\
\hline \multicolumn{6}{|c|}{ (JGB5Y, TB3M, JPYUSD, INF); AIC lag-order=5 } \\
\hline $\mathrm{r}=0$ & 68.0875 & 54.46 & $\mathrm{r}=0$ & 42.7912 & 32.24 \\
\hline $\mathrm{r} \# 1$ & $25.2963 *$ & 35.65 & $\mathrm{r} \# 1$ & 18.633 & 25.52 \\
\hline $\mathrm{r} \# 2$ & 6.6633 & 20.04 & $\mathrm{r} \# 2$ & 4.7878 & 18.63 \\
\hline $\mathrm{r} \# 3$ & 1.8755 & 6.65 & $\mathrm{r} \# 3$ & 1.8755 & 6.65 \\
\hline \multicolumn{6}{|c|}{ (JGB5Y, TB3M, JPYEUR, INF); AIC lag-order=5 } \\
\hline $\mathrm{r}=0$ & 78.2927 & 54.46 & $\mathrm{r}=0$ & 46.6675 & 32.24 \\
\hline $\mathrm{r} \# 1$ & $31.6252 *$ & 35.65 & $\mathrm{r} \# 1$ & 21.8887 & 25.52 \\
\hline $\mathrm{r} \# 2$ & 9.7366 & 20.04 & $\mathrm{r} \# 2$ & 7.465 & 18.63 \\
\hline $\mathrm{r} \# 3$ & 2.2715 & 6.65 & $\mathrm{r} \# 3$ & 2.2715 & 6.65 \\
\hline \multicolumn{6}{|c|}{ (JGB5Y, TB3M, TOPIX, JPYUSD, INF); AIC lag-order=5 } \\
\hline $\mathrm{r}=0$ & 78.9209 & 76.07 & $r=0$ & 44.2273 & 38.77 \\
\hline $\mathrm{r} \# 1$ & $34.6935^{*}$ & 54.46 & $\mathrm{r} \# 1$ & 22.0628 & 32.24 \\
\hline $\mathrm{r} \# 2$ & 12.6307 & 35.65 & $\mathrm{r} \# 2$ & 7.1259 & 25.52 \\
\hline $\mathrm{r} \# 3$ & 5.5048 & 20.04 & $\mathrm{r} \# 3$ & 4.564 & 18.63 \\
\hline $\mathrm{r} \# 4$ & 0.9408 & 6.65 & $\mathrm{r} \# 4$ & 0.9408 & 6.65 \\
\hline \multicolumn{6}{|c|}{ (JGB5Y, TB3M, TOPIX, JPYEUR, INF); AIC lag-order=5 } \\
\hline $\mathrm{r}=0$ & 96.7597 & 76.07 & $\mathrm{r}=0$ & 49.2756 & 38.77 \\
\hline $\mathrm{r} \# 1$ & $47.4841 *$ & 54.46 & $\mathrm{r} \# 1$ & 22.253 & 32.24 \\
\hline $\mathrm{r} \# 2$ & 25.2311 & 35.65 & $\mathrm{r} \# 2$ & 18.8475 & 25.52 \\
\hline $\mathrm{r} \# 3$ & 6.3836 & 20.04 & $\mathrm{r} \# 3$ & 5.5785 & 18.63 \\
\hline $\mathrm{r} \# 4$ & 0.8052 & 6.65 & $\mathrm{r} \# 4$ & 0.8052 & 6.65 \\
\hline \multicolumn{6}{|c|}{ (JGB5Y, TB3M, NIKKEI, JPYUSD, INF); AIC lag-order=5 } \\
\hline $\mathrm{r}=0$ & 78.0704 & 76.07 & $\mathrm{r}=0$ & 43.3675 & 38.77 \\
\hline $\mathrm{r} \# 1$ & $34.7029 *$ & 54.46 & $\mathrm{r} \# 1$ & 22.9996 & 32.24 \\
\hline $\mathrm{r} \# 2$ & 11.7032 & 35.65 & $\mathrm{r} \# 2$ & 7.0739 & 25.52 \\
\hline $\mathrm{r} \# 3$ & 4.6293 & 20.04 & $\mathrm{r} \# 3$ & 4.3504 & 18.63 \\
\hline $\mathrm{r} \# 4$ & 0.2789 & 6.65 & $\mathrm{r} \# 4$ & 0.2789 & 6.65 \\
\hline \multicolumn{6}{|c|}{ (JGB5Y, TB3M, NIKKEI, JPYEUR, INF); AIC lag-order=5 } \\
\hline $\mathrm{r}=0$ & 96.5448 & 76.07 & $\mathrm{r}=0$ & 51.1294 & 38.77 \\
\hline $\mathrm{r} \# 1$ & $45.4154 *$ & 54.46 & $\mathrm{r} \# 1$ & 22.7384 & 32.24 \\
\hline $\mathrm{r} \# 2$ & 22.677 & 35.65 & $\mathrm{r} \# 2$ & 17.0297 & 25.52 \\
\hline $\mathrm{r} \# 3$ & 5.6473 & 20.04 & $\mathrm{r} \# 3$ & 5.5253 & 18.63 \\
\hline $\mathrm{r} \# 4$ & 0.1220 & 6.65 & $\mathrm{r} \# 4$ & 0.122 & 6.65 \\
\hline
\end{tabular}

Notes: $r$ denotes the number of cointegrated vectors. Lag lengths were chosen by AIC. * implies significance at the 10 percent level. 


\subsubsection{Testing for Structural Breaks}

The Gregory and Hansen (1996) cointegration test extends Engle and Granger's (1987) procedure by allowing a structural break in either the intercept or the intercept and the cointegrating coefficient. The advantage of the Gregory-Hansen test is that it allows for a onetime endogenously determined structural break in the cointegrating vector.

Four different models-(JGB5Y, TB3M), (JGB5Y, TB3M, INF), (JGB5Y, TB3M, TOPIX, INF), and (JGB5Y, TB3M, TOPIX, JPYUSD, INF) - are tested for structural breaks. These models are as follows:

(i) Model C allows for cointegration with a change in intercept only.

(ii) Model $C / T$ includes a time trend into shift.

(iii) Model C/S takes into consideration the simultaneous presence of both a mean and slope break.

Each of the models has a dummy variable that is determined endogenously to allow for a structural break. The dummy is zero before a breakpoint and one afterward. The null hypothesis in all three models is that the residuals are nonstationary. The alternative hypothesis is that the residuals are stationary with one structural break at an unknown time. The unit root tests (ADF test with ADF statistic; and PP test with $Z_{t}, Z_{a}$ statistics) on the residuals obtained from those models are applied to choose the breakpoints associated with the smallest values of the unit root statistics. Asymptotic critical values are obtained from Gregory and Hansen (1996).

Table 4 shows that the null hypothesis of no cointegration is rejected by most models. In contrast to the results presented in table 3 , the findings displayed in table 4 imply that a structural change is present in the long-run cointegration equation. This finding supports the notion that the bias toward the null hypothesis with no cointegration may arise from Johansen cointegration tests when structural break or regime shifts are not properly considered. 
Table 4: Gregory and Hansen Cointegration Tests for Regime Shifts

\begin{tabular}{|c|c|c|c|c|c|c|c|c|}
\hline & \multicolumn{2}{|c|}{ (JGB5Y, TB3M) } & \multicolumn{2}{|c|}{ (JGB5Y, TB3M, INF) } & \multicolumn{2}{|c|}{$\begin{array}{l}\text { (JGB5Y, TB3M, TOPIX, } \\
\text { INF) }\end{array}$} & \multicolumn{2}{|c|}{$\begin{array}{c}\text { (JGB9Y, TB3M, } \\
\text { TOPIX, JPYUSD, INF) }\end{array}$} \\
\hline & Test Stat. & Breakpoint & Test Stat. & Breakpoint & Test Stat. & Breakpoint & Test Stat. & Breakpoint \\
\hline \multicolumn{9}{|c|}{ ADF } \\
\hline Model C & $-5.04 * *$ & $2006 / 12 / 28$ & $-5.12 * *$ & $2012 / 1 / 11$ & $-5.12 *$ & $2012 / 8 / 10$ & $-5.53 *$ & $2006 / 12 / 19$ \\
\hline Model C/T & $-5.11 * *$ & $2006 / 12 / 28$ & $-5.57 * *$ & $2006 / 1 / 4$ & $-5.93 * *$ & $2005 / 12 / 29$ & $-6.99 * * *$ & $2008 / 1 / 19$ \\
\hline Model C/S & $-6.34 * * *$ & $2006 / 6 / 5$ & $-6.16^{* *}$ & $2006 / 6 / 6$ & $-7.35 * * *$ & $2006 / 5 / 31$ & $-7.50 * * *$ & $2006 / 8 / 8$ \\
\hline \multicolumn{9}{|c|}{$\mathbf{Z}_{\mathrm{t}}$} \\
\hline Model C & $-5.13 * * *$ & $2006 / 12 / 13$ & $-5.26 * *$ & $2012 / 3 / 13$ & $-5.28 * *$ & $2012 / 3 / 13$ & $-5.72 * *$ & $2006 / 12 / 13$ \\
\hline Model C/T & $-5.22 * *$ & $2006 / 12 / 13$ & $-5.78 * *$ & $2005 / 12 / 30$ & $-6.26 * * *$ & 2008/10/1 & $-7.07 * * *$ & 2008/9/19 \\
\hline Model C/S & $-6.95 * * *$ & $2006 / 5 / 16$ & $-6.83 * * *$ & $2006 / 5 / 16$ & $-7.35 * * *$ & $2006 / 5 / 30$ & $-7.46 * * *$ & $2008 / 4 / 29$ \\
\hline \multicolumn{9}{|c|}{$\mathbf{Z}_{\mathbf{a}}$} \\
\hline Model C & $-63.58 * * *$ & $2006 / 12 / 13$ & $-61.80 * * *$ & $2012 / 3 / 13$ & $-61.69 * *$ & $2012 / 3 / 13$ & $-77.18 * * *$ & $2006 / 12 / 13$ \\
\hline Model C/T & $-65.83^{* * *}$ & $2006 / 12 / 13$ & $-68.52 * * *$ & $2005 / 12 / 30$ & $-82.69 * * *$ & $2008 / 10 / 1$ & $-101.30 * * *$ & $2008 / 9 / 19$ \\
\hline Model C/S & $-100.53 * * *$ & $2006 / 5 / 16$ & $-97.94 * * *$ & $2006 / 5 / 16$ & $-110.67 * * *$ & $2006 / 5 / 30$ & $-114.18 * * *$ & $2008 / 4 / 29$ \\
\hline
\end{tabular}

Notes: *,**, and *** imply significance at 10 percent, 5 percent, and 1 percent levels, respectively. The model specifications are denoted by C-level shift, C/T- level shift with a trend, C/T-regime trend. Critical values are based on Gregory and Hansen (1996). The results of models with JGBs of different maturity tenors and models with NIKKEI or JPYEUR are similar. The results are available upon request.

In model (JGB5Y, TB3M, TOPIX, JPYUSD, INF)—the modified Chow break test, proposed by Shehata (2011) —is applied on three break dates (2008/1/19, 2008/4/29, 2008/9/19) separately. ${ }^{3}$ This methodology provides three types of regressions, which are specified as follows: (1) independent variable (X) with a dummy; (2) X with each X multiplied with a dummy; and (3) X with both a dummy and each $\mathrm{X}$ multiplied with a dummy. The dummy is zero before a breakpoint and one afterward. As displayed in table 5, for all types of regressions, the Chow test statistics are quite large and with p-values near zero. Thus, the Chow break test results reveal that the null hypothesis of no structural breaks for all dates specified should be rejected.

There is clear and definitive evidence of cointegration between the long-term interest rate, the short-term interest rate, the inflation rate, the equity index, and the exchange rate after incorporating these structural breaks in the model.

\footnotetext{
${ }^{3}$ The results of models (JGB5Y, TB3M), (JGB5Y, TB3M, INF), and (JGB5Y, TB3M, TOPIX, INF) are similar and available upon request.
} 
Table 5: Chow Test and Structural Change Regressions

\begin{tabular}{|c|c|c|c|c|c|c|c|c|c|}
\hline & \multicolumn{9}{|c|}{ (JGB5Y, TB3M, TOPIX, JPYUSD, INF) } \\
\hline & \multicolumn{3}{|c|}{ DUM2008/1/19 } & \multicolumn{3}{|c|}{ DUM2008/4/29 } & \multicolumn{3}{|c|}{ DUM2008/9/19 } \\
\hline & $\begin{array}{l}\text { Chow } \\
\text { test_1 }\end{array}$ & $\begin{array}{l}\text { Chow } \\
\text { test_2 }\end{array}$ & $\begin{array}{l}\text { Chow } \\
\text { test_3 }\end{array}$ & $\begin{array}{l}\text { Chow } \\
\text { test_1 }\end{array}$ & $\begin{array}{l}\text { Chow } \\
\text { test_2 }\end{array}$ & $\begin{array}{l}\text { Chow } \\
\text { test_3 }\end{array}$ & $\begin{array}{l}\text { Chow } \\
\text { test_1 }\end{array}$ & $\begin{array}{l}\text { Chow } \\
\text { test_2 }\end{array}$ & $\begin{array}{l}\text { Chow } \\
\text { test_3 }\end{array}$ \\
\hline \multirow{2}{*}{ TB3M } & $1.090^{* * *}$ & $0.379 * * *$ & $0.326^{* * * *}$ & $1.084 * * *$ & $0.417^{* * *}$ & $0.375^{* * *} *$ & $1.056 * * *$ & 0.465 *** & $0.434 * * *$ \\
\hline & $(0.0172)$ & $(0.0174)$ & $(0.0176)$ & $(0.0171)$ & $(0.0172)$ & $(0.0174)$ & $(0.0172)$ & $(0.0166)$ & $(0.0167)$ \\
\hline \multirow{2}{*}{ INF } & $0.294 * * *$ & $-0.135^{* * *}$ & $-0.054 * * *$ & $0.266^{* * * *}$ & $-0.073 * * *$ & 0.0032 & $0.231 * * * *$ & -0.0222 & $0.047 * * *$ \\
\hline & $(0.0143)$ & $(0.0177)$ & $(0.0185)$ & $(0.0147)$ & $(0.0172)$ & $(0.0183)$ & $(0.0161)$ & $(0.0163)$ & $(0.0176)$ \\
\hline \multirow{2}{*}{ TOPIX } & $\begin{array}{c}4.50 \mathrm{e}-05 \\
* * *\end{array}$ & $\begin{array}{c}0.00102 \\
* * *\end{array}$ & $\begin{array}{c}0.00100 \\
* * *\end{array}$ & $\begin{array}{c}5.19 \mathrm{e}-05 \\
* * *\end{array}$ & $\begin{array}{c}0.00095 \\
* * *\end{array}$ & $\begin{array}{c}0.000936 \\
* * *\end{array}$ & $\begin{array}{l}6.90 \mathrm{e}-05 \\
* * *\end{array}$ & $\begin{array}{l}0.000881 \\
* * *\end{array}$ & $\begin{array}{c}0.000863 \\
* * *\end{array}$ \\
\hline & 0.000012 & 0.000019 & 0.000019 & 0.000012 & 0.0000018 & 0.000018 & 0.000013 & 0.000017 & 0.000017 \\
\hline \multirow{2}{*}{ JPYUSD } & $\begin{array}{c}-0.00329 \\
* * *\end{array}$ & $\begin{array}{c}-0.00576 \\
* * *\end{array}$ & -0.000681 & $\begin{array}{c}-0.00355 \\
* * *\end{array}$ & $\begin{array}{c}-0.00540 \\
* * *\end{array}$ & $\begin{array}{c}-0.00089 \\
*\end{array}$ & $\begin{array}{c}-0.00413 \\
* * *\end{array}$ & $\begin{array}{c}-0.00502 \\
* * *\end{array}$ & $\begin{array}{c}-0.00099 \\
* *\end{array}$ \\
\hline & $(0.00033)$ & $(0.00023)$ & $(0.00047)$ & $(0.00033)$ & $(0.00024)$ & $(0.00047)$ & $(0.00036)$ & $(0.00023)$ & $(0.00047)$ \\
\hline \multirow{2}{*}{$\begin{array}{c}\text { CONSTAN } \\
\mathbf{T}\end{array}$} & $0.744 * * *$ & $0.143^{* * *}$ & $-0.463 * * *$ & $0.778^{* * *}$ & $0.149^{* * *}$ & $-0.384 * * *$ & $0.838 * * *$ & $0.164 * * *$ & $-0.309 * * *$ \\
\hline & $(0.0310)$ & $(0.0212)$ & $(0.0527)$ & $(0.0316)$ & $(0.0214)$ & $(0.0528)$ & $(0.0345)$ & $(0.0217)$ & $(0.0527)$ \\
\hline \multirow{2}{*}{ DUM } & $-0.290 * * *$ & & $0.719^{* * *}$ & $-0.307 * * *$ & & $0.635^{* * *}$ & $-0.330 * * *$ & & $0.567 * * *$ \\
\hline & $(0.00943)$ & & $(0.0574)$ & $(0.00986)$ & & $(0.0576)$ & $(0.0113)$ & & $(0.0577)$ \\
\hline \multirow{2}{*}{$\begin{array}{c}\text { DUM*TB3 } \\
\text { M }\end{array}$} & & $1.048^{* * *}$ & $1.096^{* * *}$ & & $0.977^{* * *}$ & $1.016^{* * *}$ & & $0.910 * * *$ & $0.933 * * *$ \\
\hline & & $(0.0281)$ & $(0.0279)$ & & $(0.0284)$ & $(0.0283)$ & & $(0.0294)$ & $(0.0292)$ \\
\hline \multirow{2}{*}{ DUM*INF } & & $0.252 * * *$ & $0.175^{* * *}$ & & $0.149^{* * *}$ & $0.0776^{* * *}$ & & $0.0593^{* *}$ & -0.00938 \\
\hline & & $(0.0229)$ & $(0.0233)$ & & $(0.0230)$ & $(0.0236)$ & & $(0.0240)$ & $(0.0248)$ \\
\hline \multirow{2}{*}{$\begin{array}{c}\text { DUM*TOPI } \\
\mathbf{X}\end{array}$} & & $\begin{array}{c}-0.00118 \\
* * *\end{array}$ & $\begin{array}{c}-0.00112 \\
* * *\end{array}$ & & $\begin{array}{c}-0.00115 \\
* * * \\
\end{array}$ & $\begin{array}{c}-0.00109 \\
* * * \\
\end{array}$ & & $\begin{array}{c}-0.00110 \\
* * *\end{array}$ & $\begin{array}{c}-0.00105 \\
\text { *** }\end{array}$ \\
\hline & & 0.000026 & 0.000026 & & 0.000026 & 0.000026 & & 0.000026 & 0.000026 \\
\hline \multirow{2}{*}{$\begin{array}{c}\text { DUM* } \\
\text { JPYUSD }\end{array}$} & & $\begin{array}{c}0.00805 \\
* * *\end{array}$ & $\begin{array}{c}0.00127 \\
* *\end{array}$ & & $\begin{array}{c}0.00805 \\
* * *\end{array}$ & $\begin{array}{c}0.00202 \\
* * *\end{array}$ & & $\begin{array}{c}0.00777 \\
* * *\end{array}$ & $\begin{array}{c}0.00236 \\
\text { ***⿰㇇⿰亅⿱丿丶丶 }\end{array}$ \\
\hline & & $(0.00028)$ & $(0.00061)$ & & $(0.00028)$ & $(0.00062)$ & & $(0.00029)$ & $(0.00062)$ \\
\hline Obs. & 4533 & 4533 & 4533 & 4533 & 4533 & 4533 & 4533 & 4533 & 4533 \\
\hline Adj R2 & 0.842 & 0.919 & 0.922 & 0.843 & 0.918 & 0.920 & 0.8395 & 0.916 & 0.918 \\
\hline $\begin{array}{l}\text { Chow test } \\
\text { statistics }\end{array}$ & 943.916 & 1536.951 & 1303.444 & 966.626 & 1493.400 & 1250.917 & 853.547 & 1445.63 & 1200.183 \\
\hline P-value & 0.0000 & 0.0000 & 0.0000 & 0.0000 & 0.0000 & 0.0000 & 0.0000 & 0.0000 & 0.0000 \\
\hline
\end{tabular}

Notes: *,**, and *** imply significance at 10 percent, 5 percent, and 1 percent levels, respectively. Chow test types are (1) $Y=X+D U M$; (2) $Y=X+D X$; (3) $Y=X+D U M+D X$, where DUM=Dummy variable (0,1), takes (0) in first period, and (1) in second period. DX=Cross product of each $\mathrm{X}_{\mathrm{i}}$ times in DUM.

\subsubsection{Vector Error Correction Model (VECM)}

Table 6 presents the estimation of the four models with the following specification, as mentioned in section 4.1:

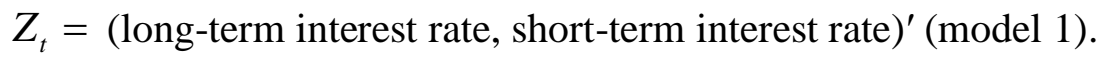

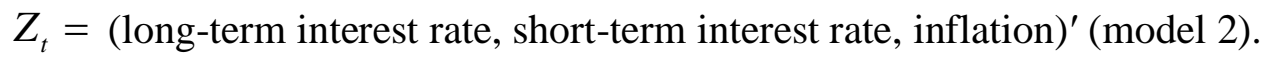

$Z_{t}=($ long-term interest rate, short-term interest rate, inflation, equity index)' (model 3). 
$Z_{t}=$ (long-term interest rate, short-term interest rate, inflation, equity index, exchange rate)' (model 4).

In model 1, the long-term interest rates are regressed only on the short-term interest rate. The coefficient is negative and highly significant. However, after adding control variables, the coefficient becomes positive and highly significant in model 2 with inflation, and negative and highly significant again in model 3 and model 4 with the equity index and exchange rate.

Diagnostic tests are performed to check for signs of misspecifications, such as serial correlation or non-normality.

First, the Breusch-Godfrey Lagrange Multiplier Test of serial correlation in the residuals shows that the null hypothesis that there is no serial correlation cannot be rejected for model 1 , model 2 , model 3, and model 4 with TOPIX (with p-values $>0.1$ ). Since in the cointegration analysis the data has been corrected for unit roots, serial correlation is not a serious problem.

Second, skewness statistics are computed to test the null hypothesis that the residuals are normally distributed. At the 1 percent level, the null hypotheses are rejected for all models (1-4) since all the p-values are less than 0.01. Thus, the results of the skewness test do not suggest that the residuals are normally distributed in the four models. However, this is neither unusual nor altogether unexpected for a macro financial time series. Indeed, such series often exhibit nonnormal distributions with fat tails. 
Table 6: Johansen VEC Model

\begin{tabular}{|c|c|c|c|c|c|c|c|c|}
\hline & Model 1 & Model 2 & \multicolumn{2}{|c|}{ Model 3} & \multicolumn{4}{|c|}{ Model 4} \\
\hline $\begin{array}{l}\text { Long-run } \\
\text { relationship }\end{array}$ & \multicolumn{8}{|c|}{ JGB5Y } \\
\hline TB3M & $\begin{array}{c}-1.890 * * * \\
(0.204)\end{array}$ & $\begin{array}{c}3.369 * * * \\
(0.863)\end{array}$ & $\begin{array}{c}-3.726 * * * \\
(0.398)\end{array}$ & $\begin{array}{c}-3.653 * * * \\
(0.408)\end{array}$ & $\begin{array}{c}-3.691 * * * \\
(0.330)\end{array}$ & $\begin{array}{c}-4.661 * * * \\
(0.740)\end{array}$ & $\begin{array}{c}-3.414 * * * \\
(0.370)\end{array}$ & $\begin{array}{c}-3.389 * * * \\
(0.582)\end{array}$ \\
\hline INF & & $\begin{array}{c}-3.958 * * * \\
(0.549) \\
\end{array}$ & $\begin{array}{c}1.779 * * * \\
(0.294) \\
\end{array}$ & $\begin{array}{c}1.742 * * * \\
(0.285)\end{array}$ & $\begin{array}{c}1.568 * * * \\
(0.233) \\
\end{array}$ & $\begin{array}{c}3.888 * * * \\
(0.577) \\
\end{array}$ & $\begin{array}{c}1.515 * * * \\
(0.252) \\
\end{array}$ & $\begin{array}{c}2.828 * * * \\
(0.424) \\
\end{array}$ \\
\hline TOPIX & & & $\begin{array}{l}-0.000158 \\
(0.00018)\end{array}$ & & $\begin{array}{c}-0.000734 * * * \\
(0.00025)\end{array}$ & $\begin{array}{l}0.000662 \\
(0.00045)\end{array}$ & & \\
\hline NIKKEI & & & & $\begin{array}{l}-7.57 \mathrm{e}-06 \\
(1.41 \mathrm{e}-05)\end{array}$ & & & $\begin{array}{l}-3.43 e-06 \\
(2.36 e-05)\end{array}$ & $\begin{array}{c}0.000054 * * \\
(2.66 \mathrm{e}-05)\end{array}$ \\
\hline JPYUSD & & & & & $\begin{array}{l}0.0130 * * \\
(0.00571) \\
\end{array}$ & & $\begin{array}{l}-0.00162 \\
(0.00725) \\
\end{array}$ & \\
\hline JPYEUR & & & & & & $\begin{array}{c}-0.0348 * * * \\
(0.0120)\end{array}$ & & $\begin{array}{c}-0.0276^{* * * *} \\
(0.00885)\end{array}$ \\
\hline CONSTANT & -0.465 & 0.432 & -0.244 & -0.488 & -1.417 & 2.842 & -0.442 & 2.219 \\
\hline \multicolumn{9}{|c|}{ Error correction terms } \\
\hline Eq. JGB5Y & $\begin{array}{l}-0.000065 \\
(0.00139) \\
\end{array}$ & $\begin{array}{c}-0.00125 * * * \\
(0.000361) \\
\end{array}$ & $\begin{array}{l}0.000860 \\
(0.00086) \\
\end{array}$ & $\begin{array}{l}0.000757 \\
(0.00087) \\
\end{array}$ & $\begin{array}{l}0.000754 \\
(0.00103) \\
\end{array}$ & $\begin{array}{l}0.000671 \\
(0.00047) \\
\end{array}$ & $\begin{array}{l}0.000716 \\
(0.00099) \\
\end{array}$ & $\begin{array}{l}0.000658 \\
(0.00064) \\
\end{array}$ \\
\hline Eq. TB3M & $\begin{array}{c}0.00450 \text { *** } \\
(0.00090)\end{array}$ & $\begin{array}{c}-0.00105 * * * \\
(0.000233)\end{array}$ & $\begin{array}{c}0.00337 * * * \\
(0.00055)\end{array}$ & $\begin{array}{c}0.00336 * * * \\
(0.00056)\end{array}$ & $\begin{array}{c}0.00452 * * * \\
(0.000669)\end{array}$ & $\begin{array}{c}0.00162 * * * \\
(0.00030)\end{array}$ & $\begin{array}{c}0.00413 * * * \\
(0.00064)\end{array}$ & $\begin{array}{c}0.00224 * * * \\
(0.00041)\end{array}$ \\
\hline Eq. INF & & $\begin{array}{c}0.00177 * * * \\
(0.000561)\end{array}$ & $\begin{array}{c}-0.00529 * * * \\
(0.00133)\end{array}$ & $\begin{array}{c}-0.00555 * * * \\
(0.00134)\end{array}$ & $\begin{array}{c}-0.00704 * * * \\
(0.00161)\end{array}$ & $\begin{array}{c}-0.00344 * * * \\
(0.00073)\end{array}$ & $\begin{array}{c}-0.00573 * * * \\
(0.00154)\end{array}$ & $\begin{array}{c}-0.00453 * * * \\
(0.00099)\end{array}$ \\
\hline Eq. TOPIX & & & $\begin{array}{l}-0.597 \\
(0.636)\end{array}$ & & $\begin{array}{c}0.305 \\
(0.754)\end{array}$ & $\begin{array}{l}-0.457 \\
(0.342)\end{array}$ & & \\
\hline Eq. NIKKEI & & & & $\begin{array}{l}-10.41 \\
(7.711) \\
\end{array}$ & & & $\begin{array}{l}-8.906 \\
(8.650) \\
\end{array}$ & $\begin{array}{c}-12.33 * * \\
(5.621) \\
\end{array}$ \\
\hline Eq. JPYUSD & & & & & $\begin{array}{l}-0.0619 * \\
(0.0327)\end{array}$ & & $\begin{array}{l}-0.0545^{*} \\
(0.0313)\end{array}$ & \\
\hline Eq. JPYEUR & & & & & & $\begin{array}{l}-0.00198 \\
(0.0205)\end{array}$ & & $\begin{array}{c}-0.000766 \\
(0.0280)\end{array}$ \\
\hline \multicolumn{9}{|c|}{ Diagnostics } \\
\hline Obs. & 4528 & 4528 & 4528 & 4528 & 4528 & 4528 & 4528 & 4528 \\
\hline Lags & 5 & 5 & 5 & 5 & 5 & 5 & 5 & 5 \\
\hline AIC & -10.645 & -14.656 & -6.423 & -1.434 & -4.567 & -3.905 & 0.411 & 1.082 \\
\hline Log likelihood & 24126.92 & 33230.58 & 14632.33 & 3335.10 & 10474.62 & 8974.88 & -796.50 & -2316.01 \\
\hline $\begin{array}{l}\text { Serial } \\
\text { correlation test }\end{array}$ & 5.742 & 13.012 & 22.050 & 27.808 & 34.237 & 37.067 & 41.079 & 42.746 \\
\hline P-value & 0.219 & 0.162 & 0.142 & 0.033 & 0.103 & 0.057 & 0.023 & 0.015 \\
\hline Skewness test & 322.881 & 59000 & 59000 & 59000 & 59000 & 59000 & 59000 & 59000 \\
\hline P-value & 0.0000 & 0.0000 & 0.0000 & 0.0000 & 0.0000 & 0.0000 & 0.0000 & 0.0000 \\
\hline
\end{tabular}

Notes: *,**, and *** implies significance at 10 percent, 5 percent, and 1 percent levels respectively. Test statistics and p-values are presented in respective rows. The results of all other long-term interest rates with dummy variables are available upon request. 


\subsubsection{Interpretation of VEC Model Results}

Based on the post-estimation statistics, model 4 with TOPIX and JPYUSD in table 6 is treated here as a baseline model for further examination. After normalizing on the long-term interest rate, the cointegrating vectors associated with the largest eigenvalues yield the following cointegrating relationship: ${ }^{4}$

$$
J G B 5 Y=1.417+3.691 \text { TB3M }-1.568 I N F+0.000734 \text { TOPIX }-0.013 \text { JPYUSD }
$$

The results of equation (2) show that there is a significant long-run relationship between the short-term interest rate, inflation, the equity index, the exchange rate, and the long-term interest rate after incorporating structural breaks into the cointegrating vector. There also is a significant positive relationship between the short-term interest rate and the long-term interest rate. A 1 percentage point increase in the short-term interest rate is associated with a 369.1 basis point increase in the long-term interest rate.

The error correction terms presented in the middle panel of table 6 are derived from the long-run cointegration relationship. The significance of the error correction terms indicates the long-term causal relationship. Model 4 with NIKKEI and JPYUSD has a negative and highly significant coefficient of error correction term for one of the four equations: Eq. INF. This implies that there is a long-run cointegration equation with INF as the "dependent variable." In that specification, the long-run cointegration equation has significant coefficients for all the variables. This is consistent with the results obtained from the cointegration tests. The value of this coefficient $(-0.00344)$, that is, the speed of return to the equilibrium long-term interest rates, appears to be relatively moderate: a 1 percent shock away from the equilibrium long-term interest rate in day zero is corrected by 0.00344 percent in day one. The error correction terms for the other three equations are either insignificant or positive. Thus, the cointegration relation only enters significantly in the long-term interest rate equation. When the adjustment coefficients in model 4 with TOPIX and JPYUSD are carefully examined, two (Eq. INF and Eq. JPYUSD) of the four

\footnotetext{
${ }^{4}$ Signs in table 6 are reversed because of the normalization process.
} 
adjustment coefficients turn out to have negative and significant signs. This indicates an adjustment process of the short-run disequilibrium in the cointegration system toward the longrun equilibrium. In contrast, the estimated error correction term in the equations of JGB5Y, TB3M and TOPIX does not contribute to the error correction adjustment.

Turning to the short-run estimates for Model 4 with TOPIX and JPYUSD (see table 7), the inflation rate has a positive and significant effect on the long-term interest rates when lagged three days (0.0198) and the exchange rate has a positive and significant effect when lagged one day (0.0033). However, changes in the equity index have significant effects with different signs. It is negative when lagged one day (-0.000061), and positive when lagged four days (0.000049). Thus, the net effect of equity index on long-term interest rates is ambiguous, while both inflation and the exchange rate have positive effects on the long-term interest rate in the short run. 
Table 7: Short-Run Adjustment Coefficients (model 4, table 6)

\begin{tabular}{|c|c|c|}
\hline \multirow[t]{2}{*}{ Model } & \multicolumn{2}{|c|}{ (JGB5Y, TB3M, TOPIX, JPYUSD, INF) } \\
\hline & Coeffi. & Std. error \\
\hline ECT & 0.000754 & $(0.00103)$ \\
\hline$\triangle \mathrm{JGB5Y}(-1)$ & -0.0124 & $(0.0156)$ \\
\hline$\Delta$ JGB5Y(-2) & -0.00263 & $(0.0156)$ \\
\hline$\Delta$ JGB5Y(-3) & $-0.0360 * *$ & $(0.0156)$ \\
\hline$\triangle$ JGB5Y(-4) & 0.00941 & $(0.0156)$ \\
\hline$\Delta$ TB3M(-1) & 0.0110 & $(0.0229)$ \\
\hline$\Delta \mathrm{TB3M}(-2)$ & 0.00522 & $(0.0231)$ \\
\hline$\Delta \mathrm{TB3M}(-3)$ & -0.00390 & $(0.0231)$ \\
\hline$\triangle \mathrm{TB3M}(-4)$ & 0.00447 & $(0.0229)$ \\
\hline$\Delta I N F(-1)$ & 0.00997 & $(0.00990)$ \\
\hline$\Delta I N F(-2)$ & -0.000646 & $(0.00991)$ \\
\hline$\Delta I N F(-3)$ & $0.0198 * *$ & $(0.00989)$ \\
\hline$\Delta I N F(-4)$ & -0.00453 & $(0.00989)$ \\
\hline$\Delta$ TOPIX(-1) & $-0.000061 * * *$ & $(2.20 \mathrm{e}-05)$ \\
\hline$\Delta$ TOPIX(-2) & 0.0000101 & $(2.21 \mathrm{e}-05)$ \\
\hline$\Delta$ TOPIX(-3) & -0.000005 & $(2.21 \mathrm{e}-05)$ \\
\hline$\Delta$ TOPIX(-4) & $0.000049 * *$ & $(2.16 \mathrm{e}-05)$ \\
\hline$\Delta$ JPYUSD(-1) & $0.0033 * * *$ & $(0.000500)$ \\
\hline$\triangle$ JPYUSD(-2) & -0.0000533 & $(0.000512)$ \\
\hline$\triangle$ JPYUSD(-3) & -0.000358 & $(0.000512)$ \\
\hline$\triangle$ JPYUSD(-4) & 0.000186 & $(0.000510)$ \\
\hline DUM1299 & 0.000872 & $(0.00131)$ \\
\hline DUM1749 & 0.00136 & $(0.00368)$ \\
\hline DUM1786 & -0.00161 & $(0.00430)$ \\
\hline DUM1852 & -0.000491 & $(0.00263)$ \\
\hline CONSTANT & 0.0000231 & $(0.000729)$ \\
\hline
\end{tabular}

Notes: ** and *** imply significance at 5 percent and 1 percent, respectively. " $\Delta \mathrm{X}(-1)$ " represents one lag of the first difference variable; " $\Delta \mathrm{X}(-2)$ " represents two lags of the first difference variable $\mathrm{X}$.

\subsection{Stability Tests}

A graphical procedure, following Brown, Durbin, and Evans (1975), is applied to evaluate the constancy of the estimated coefficients. The procedure is based on recursive estimation to evaluate the stability of the cointegrating vector and the error correction terms. If the model is stable, one should expect the estimated coefficients to display random fluctuation and noise. The stability tests are carried out by starting with a subsample of 1,000 observations, then 
sequentially adding one observation at a time and running the regression until the end of the sample is reached. The results are plotted in figure 29.

The top panel in figure 29 shows the series of recursive estimated coefficients attached to the error correction terms. The error correction terms of the long-term interest rates equation (alpha1), short-term interest rates equation (alpha2), inflation rates equation (alpha3), and Japanese yen to euro exchange rate equation (alpha5) are set to some fairly constant levels through the recursive procedures and are all stable. The error correction terms of the equity index equation (alpha4) appear unstable. However, as sample size increases, the estimated coefficient settles down to a value around 0.3 .

In the bottom panel of figure 29 , the series of recursive estimated coefficients of the cointegrating vector are plotted. The estimated coefficients of Japanese yen to euro exchange rate (beta3), inflation rates (beta4), and the recursive intercept (beta5) are stable, while the estimated coefficients of short-term interest rates (beta2) appear unstable. However, these coefficients only fluctuate several times and, as the sample size increases, the estimated coefficient settles down to a value around -3.69 . Overall, figure 29 provides clear evidence of the stability of the coefficients in the estimated model. 
Figure 29: Results of Stability Tests
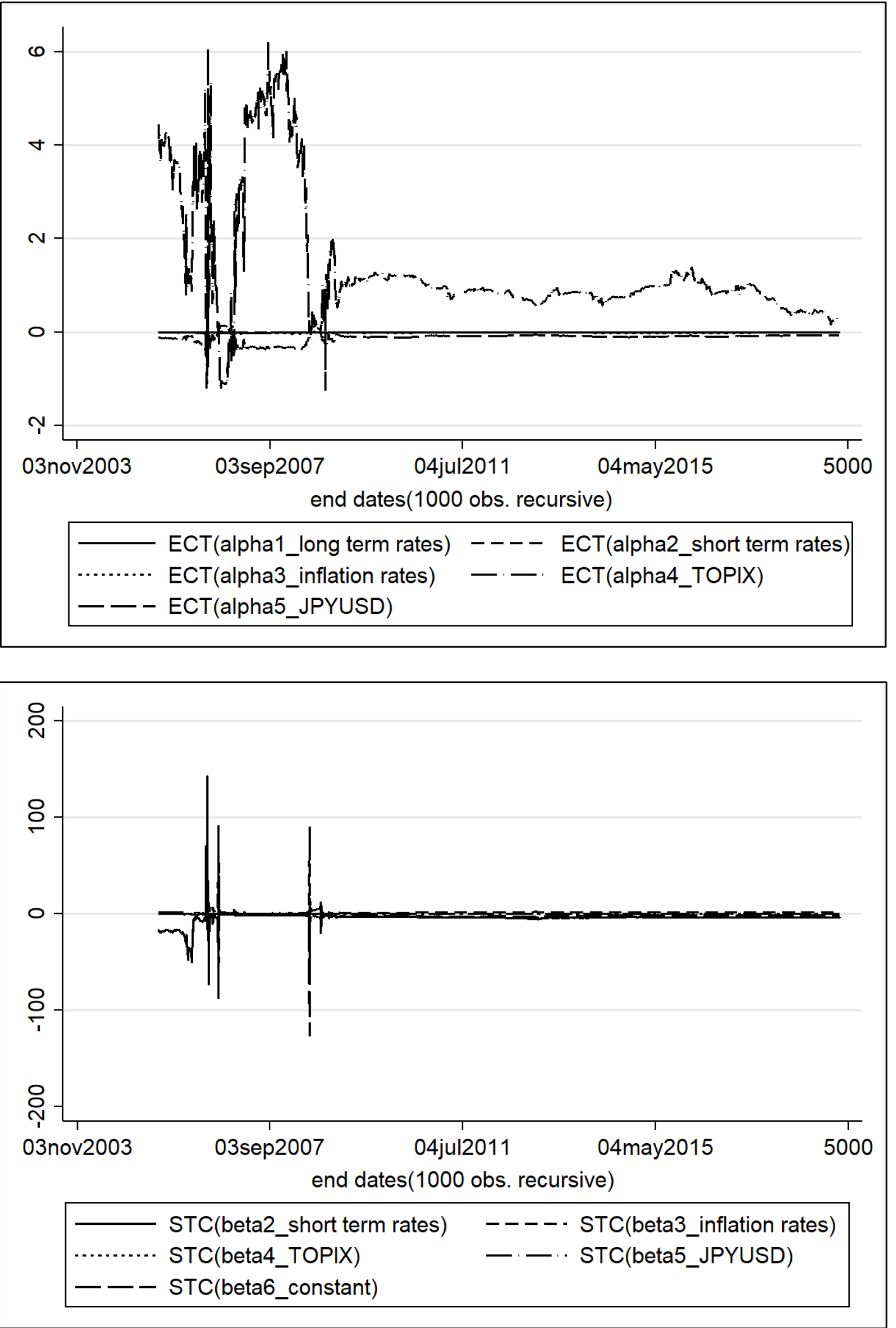


\section{IMPLICATIONS FROM A KEYNESIAN PERSPECTIVE}

The findings from theses empirical models of JGB yields using daily data have implications that are relevant for macroeconomic theory and policy.

First, the short-term interest rate has an economic and statistically important effect on JGB nominal yields. Since the short-term interest rate moves in tandem with the BoJ's policy rate, the BoJ does and can exert a decisive influence on the long-term interest rate by its policy decisions. When the short-term interest rate rises (declines), the long-term interest rate on JGBs rises (declines). The effect is markedly more than what one would expect under a conventional view, but it accords well with Keynes's (1930, 353-64) astute and farsighted observations.

Second, commodity inflation has an effect on JGB yields. The effect of commodity prices on the nominal yields appears, at first glance, to be contrary to priors or expectations since higher (lower) commodity inflation results in lower (higher) JGB yields. However, there is an entirely plausible explanation for these phenomena. The policy rate and the short-term interest rate rise (decline) when inflationary pressure and expectations increase (decrease). Hence, the effect of inflation on the long-term interest rate may occur primarily the though the short-term interest rate, particularly if the BoJ follows some type of Taylor rule. The effect of the exchange rate on JGBs may also be explained in light of the BoJ following a Taylor rule. A depreciation (appreciation) of the yen causes the BoJ to tighten monetary policy and raise (lower) its policy rate because a weaker (stronger) exchange rate could be inflationary (deflationary). Hence, the primary effect of the exchange rate on the long-term interest rate occurs via the short-term interest rate. After controlling for the short-term interest rate, the effect of commodity prices and the exchange rate on JGB yields is negative rather than positive.

Third, the effects of the equity index on JGB yields are well-aligned with priors or expectations. A higher (lower) equity index is associated with higher JGB yields, as investors may shun (seek) government bonds when the outlook for growth in nominal GDP, corporate revenues, and profits is more sanguine (bleak). 
Fourth, the models presented here show that the dynamics of JGB yields can be well explained by incoming macroeconomic information available to investors on a daily basis, such as the policy rate, commodity prices, exchange rate, equity index, and so forth. Investors in JGBs are less concerned about debt dynamics and fiscal conditions of the Japanese government than what some scholars may believe. Investors in JGBs recognize - whether consciously or unconsciously - the operational ability of the Japanese government (in conjunction with the BoJ, which is its banker) to service its debt obligations denominated in the Japanese yen.

Fifth, the models corroborate Keynes's claim that the central bank exerts a strong influence on the long-term interest rate on government bonds. While the findings here show the strong influence of the short-term interest rate on the long-term interest rate, it must be recognized that the BoJ has a wide array of tools - consisting of not just policy rates, but also balance sheet policies, forward guidance, large-scale asset purchases, yield curve control, moral persuasion, regulatory authority and supervisory capabilities, and fiscal-monetary coordination-to affect the long-term interest rate on government bonds. The findings of this paper are in concordance with the results obtained from studies using quarterly and monthly data for modeling the dynamics of JGB yields.

\section{CONCLUSION}

This paper has modeled the dynamics of JGB nominal yields using daily data. Models based on daily data can be useful not only to investors and market analysts, but also to central bankers and other policymakers to assess financial conditions and macroeconomic developments in real time. The results obtained show that the long-term JGB nominal yields can be modeled using the short-term interest rate on Treasury bills, the equity index, exchange rate, commodity inflation, and other key financial variables. The estimated models confirm that Keynes's assertion about the relationship between the short-term interest rate and the long-term interest rate has a strong empirical foundation, as manifested in the dynamics of JGB yields. The Keynesian perspective can very well explain why JGB yields have remained persistently low for many decades. 


\section{REFERENCES}

Akram, T. 2014. “The Economics of Japan's Stagnation.” Business Economics 49(3): 156-75.

—. 2016. “Japan’s Liquidity Trap.” Levy Institute Working Paper No. 862. Annandale-onHudson, NY: Levy Economics Institute of Bard College.

— 2019. "The Japanese Economy: Stagnation, Recovery, and Challenges." Journal of Economic Issues 53(2): 403-10.

Akram, T., and A. Das. 2014a. "Understanding the Low Yields of the Long-Term Japanese Sovereign Debt.” Journal of Economic Issues 48(2): 331-40.

— . 2014b. "The Determinants of Long-Term Japanese Government Bonds' Low Nominal Yields." Levy Institute Working Paper No. 818. Annandale-on-Hudson, NY: Levy Economics Institute of Bard College.

- 2015. "A Keynesian Explanation of Indian Government Bond Yields." Journal of Post Keynesian Economics 38(4): 565-87.

— 2017. "The Dynamics of Government Bond Yields in the Eurozone." Annals of Financial Economics 12(3): 1750011-18.

— 2019. "The Long-Run Determinants of Indian Government Bond Yields," Asian Development Review 36(1): 168-205.

Akram, T., and H. Li. 2016. "The Empirics of Long-Term U.S. Interest Rates.” Levy Institute Working Paper No. 863. Annandale-on-Hudson, NY: Levy Economics Institute of Bard College.

—. 2017. "What Keeps Long-Term U.S. Interest Rates So Low?" Economic Modelling 60: $380-90$.

_. 2018. “The Dynamics of JGBs' Nominal Yields,” Levy Institute Working Paper No. 906. Annandale-on-Hudson, NY: Levy Economics Institute of Bard College.

_ 2019a. "The Impact of the Bank of Japan's Monetary Policy on Japanese Government Bonds' Low Nominal Yields." Levy Institute Working Paper No. 938. Annandale-onHudson, NY: Levy Economics Institute of Bard College.

— . 2019b. "An Inquiry Concerning Long-Term U.S. Interest Rates Using Monthly Data." Applied Economics. Available at: https://doi.org/10.1080/00036846.2019.1693696 (accessed Jan 12, 2020).

Atasoy, B.S., H.M. Ertuğrul and A. Ozun. 2014. "The Puzzle of Low Government Bond Yields in Japan.” The Japanese Political Economy 40(2): 24-47. 
Baldacci, E., and M. Kumar. 2010. "Fiscal Deficits, Public Debt and Sovereign Bond Yields." IMF Working Paper No. 10/184. Washington, DC: International Monetary Fund.

Bindseil, U. 2004. Monetary Policy Implementation: Theory, Past, and Present. Oxford and New York: Oxford University Press.

Bölükbaş, M. 2018. "The Fiscal Theory of The Price Level: An Analysis for Fragile Countries." In İsmail Şiriner and Zişan Yardım Kiliçkan (eds.), Institutions, Development \& Economic Growth. London: IJOPEC.

Brown, R.L., J. Durbin, and J.M. Evans. 1975. "Techniques for Testing the Constancy of Regression Relationships Over Time." Journal of the Royal Statistical Society, Series B (Methodological) 37(2): 149-92.

Davidson, P. 2015. Post Keynesian Theory and Policy: A Realistic Analysis of the Market Oriented Capitalist Economy. Cheltenham, UK, and Northampton, MA: Edward Elgar.

Dickey, D.A., and W.A. Fuller. 1979. "Distribution of the Estimators for Autoregressive Time Series with a Unit Root." Journal of the American Statistical Association 74(366): $427-$ 31.

- 1981. "Likelihood Ratio Statistics for Autoregressive Time Series with a Unit Root." Econometrica 49(4): 1057-72.

Doi, T., T. Hoshi, and T. Okimoto. 2011. "Japanese Government Debt and Sustainability of Fiscal Policy." Journal of the Japanese and International Economies 25(4): 414-33.

Engle, R.F., and C.W.J. Granger. 1987. "Co-Integration and Error Correction: Representation, Estimation and Testing." Econometrica 55(2): 251-76.

Fullwiler, S.T. 2016. "The Debt Ratio and Sustainable Macroeconomic Policy.” World Economic Review 7: 12-42.

—. (2008)2017. "Modern Central Bank Operations: The General Principles.” In LouisPhilippe Rochon and Sergio Rossi (eds.), Advances in Endogenous Money Analysis. Northampton, MA: Edward Elgar.

Garside, W.R. 2012. Japan's Great Stagnation Forging Ahead, Falling Behind. Glasgow, UK, and Northampton, MA: Edward Elgar.

Gregory, A.W., and B.E. Hansen. 1996. "Residual-Based Tests for Cointegration in Models with Regime Shifts.” Journal of Econometrics 70(1): 99-126.

Gruber, J.W., and S.B. Kamin. 2012. "Fiscal Positions and Government Bond Yields in OECD Countries." Journal of Money, Credit, and Banking 44(8): 1563-87. 
Hansen, G., and S. İmrohoroğlu. 2013. "Fiscal Reform and Government Debt in Japan: A Neoclassical Perspective.” Review of Economic Dynamics 21: 201-24.

Horioka, C.Y., T. Nomoto, and A. Terada-Hagiwara. 2014. "Why Has Japan's Massive Government Debt Not Wreaked Havoc (Yet)?” The Japanese Political Economy 40(2): $3-23$.

Hoshi, T., and T. Ito. 2012. "Defying Gravity: How Long Will Japanese Government Bond Prices Remain High?” NBER Working Paper 18287. Cambridge, MA: National Bureau of Economic Research.

- 2013. "Is the Sky the Limit? Can Japanese Government Bonds Continue to Defy Gravity?" Asian Economic Policy Review 8(2): 218-47.

- 2014. "Defying Gravity: Can Japanese Sovereign Debt Continue to Increase without a Crisis?” Economic Policy 29(77): 5-44.

Institute for Monetary and Economic Studies. 2012. Functions and Operations of the Bank of Japan. Tokyo: Institute for Monetary and Economic Studies, Bank of Japan.

Johansen, S. 1988. "Statistical Analysis of Cointegration Vectors." Journal of Economic Dynamics and Control 12(2): 231-54.

- 1991. "Estimation and Hypothesis Testing of Cointegration Vectors in Gaussian Vector Autoregressive Models.” Econometrica 59(6): 1551-80.

-1995. Likelihood-Based Inference in Cointegrated Vector Autoregressive Models. Oxford: Clarendon Press.

Johansen, S., and K. Juselius. 1990. "Maximum Likelihood Estimation and Inference on Cointegration With Applications to the Demand for Money." Oxford Bulletin of Economics and Statistics 52(2): 169-210.

Keynes, J.M. 1930. A Treatise on Money, Vol. II: The Applied Theory of Money. London: Macmillan.

- (1936)2007. The General Theory of Employment, Interest, and Money. New York: Palgrave Macmillan.

Kregel, J. 2011. “Was Keynes's Monetary Policy À Outrance in the Treatise, A Forerunner of ZIRP and QE? Did He Change His Mind in the General Theory?" Policy Note No. 2011/4. Annandale-on-Hudson, NY: Levy Economics Institute of Bard College.

Kurihara, Y. 2015. “Asset Price and Monetary Policy: The Japanese Case.” Journal of Applied Finance and Banking 5(4): 1-9. 
Lam, R.W., and K. Tokuoka. 2013. "Assessing the Risks to the Japanese Government Bond (JGB) Market.” Journal of International Commerce, Economics and Policy 4(1): 1350002-1-1350002-15.

Lavoie, M. 2014. Post-Keynesian Economics: New Foundations. Cheltenham, UK, and Northampton, MA: Edward Elgar.

Lerner, A.P. 1943. "Functional Finance and the Federal Debt." Social Research 10(1): 38-51. . 1947. "Money as a Creature of the State." American Economic Review 37(2): 312-17.

Levrero, E.S., and M. Deleidi. 2019. "The Causal Relationship Between Short-and Long-Term Interest Rates: An Empirical Assessment of the United States," MPRA Paper No. 93608. Munich: Munich University Library.

Macrobond, various years. Macrobond subscription services (accessed January 10, 2020). Available at: https://www.macrobond.com

Malliaropulos, D., and P. Migiakis. 2018. "Quantitative Easing and Sovereign Bond Yields: A Global Perspective.” Bank of Greece Working Paper No. 253. Athens: Bank of Greece.

Mattos, O.B., F. Da Roz, F.O. Ultremare, and G.S. Mello. 2019. "Unconventional Monetary Policy and Negative Interest Rates: A Post-Keynesian Perspective on the Liquidity Trap and Euthanasia of the Rentier." Review of Keynesian Economics 7(2): 185-200.

Mitchell, W.F. 2015. Eurozone Dystopia: Groupthink and Denial on a Grand Scale. Cheltenham, UK: Edward Elgar.

Paccagnini, A. 2016. "The Macroeconomic Determinants of the U.S. Term Structure During the Great Moderation.” Economic Modelling 52(A): 216-25.

Phillips, P.C.B., and P. Perron. 1988. "Testing for a Unit Root in Time Series Regression.” Biometrika 75(2): 335-46.

Radalet, S., and J. Sachs. 1998. "The Onset of the East Asian Financial Crisis." NBER Working Paper No. 6680. Cambridge, MA: National Bureau of Economic Research.

Patra M.D., S. Pattanaik, J. John, and H.K. Behera. 2016. "Monetary Policy Transmission in India: Do Global Spillovers Matter?” RBI Occasional Papers No. 37(1\&2). Mumbai: Reserve Bank of India.

Poghosyan, T. 2014. "Long-Run and Short-Run Determinants of Sovereign Bond Yields in Advanced Economies." Economic Systems 38(1): 100-14.

Riefler, W.W. 1930. Money Rates and Money Markets in the United States. New York and London: Harper \& Brothers. 
Reinhart, C.M., and K.S. Rogoff. 2009. This Time Is Different: Eight Centuries of Financial Folly. Princeton, NJ: Princeton University Press.

Sau, L. 2018. "Coping with Deflation and the Liquidity Trap in the Eurozone: A Post Keynesian Approach." Journal of Post Keynesian Economics 41(2): 210-35.

Shehata, E.A.E. 2011. "CHOWREG: Stata Module to Estimate Structural Change Regressions and Compute Chow Test." Available at: http://fmwww.bc.edu/repec/bocode/c/chowreg.ado (accessed January 12, 2020).

Simoski, S. 2019. "A Keynesian Exploration of the Determinants of Government Bond Yields for Brazil, Colombia and Mexico." Master of Science thesis, Levy Economics Institute of Bard College. Annandale-on-Hudson, NY: Levy Economics Institute of Bard College.

Tcherneva, P.R. 2011. "Bernanke's Paradox: Can He Reconcile His Position on the Federal Budget with His Recent Charge to Prevent Deflation?" Journal of Post Keynesian Economics 33(3): 411-34.

Tkačevs, O., and K. Vilerts. 2016. "The Impact of Sovereign Bond Yields on Fiscal Discipline." Latvijas Banka Working Paper No. 5/2016. Riga, Latvia: Latvijas Banka.

—. 2019. "The Impact of Government Borrowing Costs on Fiscal Discipline." Kyklos 729(3): 446-71.

Tokuoka, K. 2010. “The Outlook for Financing Japan's Public Debt.” IMF Working Paper No. 10/19. Washington DC: International Monetary Fund.

Vinod, H.D., L. Chakraborty, and H. Karun. 2014. "If Deficits Are Not the Culprit, What Determines Indian Interest Rates? An Evaluation Using the Maximum Entropy Bootstrap Method." Levy Institute Working Paper No. 811. Annandale-on-Hudson, NY: Levy Economics Institute of Bard College.

Wray, L.R. (1998)2003. Understanding Modern Money: The Key to Full Employment and Price Stability. Cheltenham, UK, and Northampton, MA: Edward Elgar.

— 2012. Modern Money Theory: A Primer on Macroeconomics for Sovereign Monetary Systems. New York: Palgrave Macmillan. 


\section{APPENDIX}

Table A1: Unit Root Tests (Levels)

\begin{tabular}{|c|c|c|c|c|c|}
\hline Variable & & Tests & Statistic & P-value & Obs. \\
\hline \multirow{6}{*}{ JGB2Y } & \multirow{2}{*}{ Trend } & $\mathrm{ADF}$ & -1.754 & 0.726 & 4955 \\
\hline & & $\mathrm{PP}$ & -1.769 & 0.720 & 4955 \\
\hline & \multirow{2}{*}{ No trend } & $\mathrm{ADF}$ & -1.387 & 0.589 & 4955 \\
\hline & & PP & -1.400 & 0.582 & 4955 \\
\hline & \multirow{2}{*}{ No trend, no constant } & $\mathrm{ADF}$ & -1.430 & & 4955 \\
\hline & & $\mathrm{PP}$ & -1.439 & & 4955 \\
\hline \multirow{6}{*}{ JGB3Y } & \multirow{2}{*}{ Trend } & $\mathrm{ADF}$ & -2.087 & 0.553 & 4955 \\
\hline & & $\mathrm{PP}$ & -2.124 & 0.532 & 4955 \\
\hline & \multirow{2}{*}{ No trend } & $\mathrm{ADF}$ & -1.556 & 0.506 & 4955 \\
\hline & & PP & -1.588 & 0.490 & 4955 \\
\hline & \multirow{2}{*}{ No trend, no constant } & $\mathrm{ADF}$ & -1.551 & & 4955 \\
\hline & & $\mathrm{PP}$ & -1.569 & & 4955 \\
\hline \multirow{6}{*}{ JGB5Y } & \multirow{2}{*}{ Trend } & $\mathrm{ADF}$ & -2.202 & 0.489 & 4955 \\
\hline & & $\mathrm{PP}$ & -2.146 & 0.520 & 4955 \\
\hline & \multirow{2}{*}{ No trend } & $\mathrm{ADF}$ & -1.548 & 0.510 & 4955 \\
\hline & & $\mathrm{PP}$ & -1.497 & 0.535 & 4955 \\
\hline & \multirow{2}{*}{ No trend, no constant } & $\mathrm{ADF}$ & -1.567 & & 4955 \\
\hline & & PP & -1.543 & & 4955 \\
\hline \multirow{6}{*}{ JGB6Y } & \multirow{2}{*}{ Trend } & $\mathrm{ADF}$ & -2.380 & 0.390 & 4955 \\
\hline & & $\mathrm{PP}$ & -2.260 & 0.456 & 4955 \\
\hline & \multirow{2}{*}{ No trend } & $\mathrm{ADF}$ & -1.590 & 0.4885 & 4955 \\
\hline & & $\mathrm{PP}$ & -1.490 & 0.539 & 4955 \\
\hline & \multirow{2}{*}{ No trend, no constant } & $\mathrm{ADF}$ & -1.602 & & 4955 \\
\hline & & $\mathrm{PP}$ & -1.562 & & 4955 \\
\hline \multirow{6}{*}{ JGB7Y } & \multirow{2}{*}{ Trend } & $\mathrm{ADF}$ & -2.593 & 0.283 & 4955 \\
\hline & & $\mathrm{PP}$ & -2.490 & 0.333 & 4955 \\
\hline & \multirow{2}{*}{ No trend } & $\mathrm{ADF}$ & -1.660 & 0.452 & 4955 \\
\hline & & $\mathrm{PP}$ & -1.580 & 0.494 & 4955 \\
\hline & \multirow{2}{*}{ No trend, no constant } & $\mathrm{ADF}$ & -1.651 & & 4955 \\
\hline & & PP & -1.626 & & 4955 \\
\hline \multirow{6}{*}{ JGB8Y } & \multirow{2}{*}{ Trend } & $\mathrm{ADF}$ & -2.912 & 0.158 & 4955 \\
\hline & & PP & -2.789 & 0.201 & 4955 \\
\hline & \multirow{2}{*}{ No trend } & ADF & -1.715 & 0.423 & 4955 \\
\hline & & PP & -1.624 & 0.471 & 4955 \\
\hline & No trend no constant & $\mathrm{ADF}$ & -1.657 & & 4955 \\
\hline & so trena, no constant & PP & -1.633 & & 4955 \\
\hline & Trend & $\mathrm{ADF}$ & -2.809 & 0.194 & 4955 \\
\hline & 11енu & PP & -2.801 & 0.197 & 4955 \\
\hline ICROY & No trend & $\mathrm{ADF}$ & -1.467 & 0.546 & 4955 \\
\hline JGBYY & No trend & PP & -1.461 & 0.553 & 4955 \\
\hline & No trond no conctont & ADF & -1.539 & & 4955 \\
\hline & No trend, no constant & PP & -1.536 & & 4955 \\
\hline & Trond $5 \mathrm{C}-\mathrm{C}$ & $\mathrm{ADF}$ & -2.957 & 0.281 & 4955 \\
\hline & irena & $\mathrm{PP}$ & -2.589 & 0.285 & 4955 \\
\hline FIOY & & ADF & -1.336 & 0.613 & 4955 \\
\hline & No trend & $\mathrm{PP}$ & -1.323 & 0.619 & 4955 \\
\hline
\end{tabular}




\begin{tabular}{|c|c|c|c|c|c|}
\hline Variable & & Tests & Statistic & P-value & Obs. \\
\hline & & $\mathrm{ADF}$ & -1.554 & & 4955 \\
\hline & No trend, no constant & PP & -1.544 & & 4955 \\
\hline \multirow{6}{*}{ JGB15Y } & \multirow{2}{*}{ Trend } & $\mathrm{ADF}$ & -2.554 & 0.301 & 4955 \\
\hline & & $\mathrm{PP}$ & -2.471 & 0.343 & 4955 \\
\hline & \multirow{2}{*}{ No trend } & $\mathrm{ADF}$ & -1.151 & 0.694 & 4955 \\
\hline & & $\mathrm{PP}$ & -1.086 & 0.720 & 4955 \\
\hline & \multirow{2}{*}{ No trend, no constant } & $\mathrm{ADF}$ & -1.429 & & 4955 \\
\hline & & $\mathrm{PP}$ & -1.429 & & 4955 \\
\hline \multirow{6}{*}{ JGB20Y } & \multirow{2}{*}{ Trend } & $\mathrm{ADF}$ & -2.491 & 0.333 & 2282 \\
\hline & & $\mathrm{PP}$ & -2.421 & 0.369 & 2282 \\
\hline & \multirow{2}{*}{ No trend } & $\mathrm{ADF}$ & -1.659 & 0.453 & 2282 \\
\hline & & $\mathrm{PP}$ & -1.658 & 0.453 & 2282 \\
\hline & \multirow{2}{*}{ No trend, no constant } & $\mathrm{ADF}$ & -2.432 & & 2282 \\
\hline & & $\mathrm{PP}$ & -2.494 & & 2282 \\
\hline \multirow{6}{*}{ JGB25Y } & \multirow{2}{*}{ Trend } & $\mathrm{ADF}$ & -2.273 & 0.449 & 2282 \\
\hline & & PP & -2.252 & 0.461 & 2282 \\
\hline & \multirow{2}{*}{ No trend } & $\mathrm{ADF}$ & -1.380 & 0.592 & 2282 \\
\hline & & $\mathrm{PP}$ & -1.374 & 0.595 & 2282 \\
\hline & \multirow{2}{*}{ No trend, no constant } & $\mathrm{ADF}$ & -2.152 & & 2282 \\
\hline & & PP & -2.178 & & 2282 \\
\hline \multirow{6}{*}{ JGB30Y } & \multirow{2}{*}{ Trend } & $\mathrm{ADF}$ & -4.964 & 0.000 & 4065 \\
\hline & & PP & -4.965 & 0.000 & 4065 \\
\hline & \multirow{2}{*}{ No trend } & $\mathrm{ADF}$ & -0.938 & 0.775 & 4065 \\
\hline & & PP & -0.942 & 0.774 & 4065 \\
\hline & \multirow{2}{*}{ No trend, no constant } & $\mathrm{ADF}$ & -0.525 & & 4065 \\
\hline & & $\mathrm{PP}$ & -0.525 & & 4065 \\
\hline \multirow{6}{*}{ JGB40Y } & \multirow{2}{*}{ Trend } & $\mathrm{ADF}$ & -1.942 & 0.633 & 2282 \\
\hline & & $\mathrm{PP}$ & -2.015 & 0.593 & 2282 \\
\hline & \multirow{2}{*}{ No trend } & $\mathrm{ADF}$ & -1.044 & 0.737 & 2282 \\
\hline & & $\mathrm{PP}$ & -1.070 & 0.727 & 2282 \\
\hline & \multirow{2}{*}{ No trend, no constant } & $\mathrm{ADF}$ & -1.638 & & 2282 \\
\hline & & PP & -1.610 & & 2282 \\
\hline \multirow{6}{*}{ TB3M } & Trend & $\mathrm{ADF}$ & -2.360 & 0.401 & 4532 \\
\hline & 11енि & PP & -1.922 & 0.643 & 4532 \\
\hline & No trend & $\mathrm{ADF}$ & -1.947 & 0.310 & 4532 \\
\hline & so tiend & $\mathrm{PP}$ & -1.485 & 0.541 & 4532 \\
\hline & No trend no constant & $\mathrm{ADF}$ & -1.890 & & 4532 \\
\hline & & $\mathrm{PP}$ & -1.475 & & 4532 \\
\hline & Trend & $\mathrm{ADF}$ & -2.276 & 0.447 & 4955 \\
\hline & Irena & $\mathrm{PP}$ & -2.237 & 0.469 & 4955 \\
\hline TOPIX & & $\mathrm{ADF}$ & -1.987 & 0.292 & 4955 \\
\hline IOPIX & No trend & PP & -1.942 & 0.312 & 4955 \\
\hline & No trand no conctant & $\mathrm{ADF}$ & -0.696 & & 4955 \\
\hline & No trend, no constant & PP & -0.690 & & 4955 \\
\hline & Trond & $\mathrm{ADF}$ & -2.494 & 0.331 & 4955 \\
\hline & Irena & PP & -2.441 & 0.358 & 4955 \\
\hline NIKKEI & & $\mathrm{ADF}$ & -1.515 & 0.526 & 4955 \\
\hline & No trend & PP & -1.439 & 0.564 & 4955 \\
\hline & No trend, no constant & $\mathrm{ADF}$ & -0.360 & & 4955 \\
\hline
\end{tabular}




\begin{tabular}{|c|c|c|c|c|c|}
\hline Variable & & Tests & Statistic & P-value & Obs. \\
\hline & & PP & -0.333 & & 4955 \\
\hline \multirow{6}{*}{ JPYUSD } & \multirow{2}{*}{ Trend } & $\mathrm{ADF}$ & -1.831 & 0.689 & 4955 \\
\hline & & PP & -1.782 & 0.713 & 4955 \\
\hline & \multirow{2}{*}{ No trend } & ADF & -1.739 & 0.411 & 4955 \\
\hline & & $\mathrm{PP}$ & -1.690 & 0.436 & 4955 \\
\hline & \multirow{2}{*}{ No trend, no constant } & $\mathrm{ADF}$ & -0.043 & & 4955 \\
\hline & & $\mathrm{PP}$ & -0.030 & & 4955 \\
\hline \multirow{6}{*}{ JPYEUR } & \multirow{2}{*}{ Trend } & $\mathrm{ADF}$ & -2.214 & 0.522 & 4955 \\
\hline & & PP & -2.136 & 0.526 & 4955 \\
\hline & \multirow{2}{*}{ No trend } & $\mathrm{ADF}$ & -2.209 & 0.203 & 4955 \\
\hline & & $\mathrm{PP}$ & -2.203 & 0.205 & 4955 \\
\hline & \multirow{2}{*}{ No trend, no constant } & $\mathrm{ADF}$ & 0.056 & & 4955 \\
\hline & & $\mathrm{PP}$ & 0.060 & & 4955 \\
\hline \multirow{6}{*}{ Inflation Rate } & \multirow{2}{*}{ Trend } & $\mathrm{ADF}$ & -3.716 & 0.021 & 4695 \\
\hline & & $\mathrm{PP}$ & -3.404 & 0.051 & 4695 \\
\hline & \multirow{2}{*}{ No trend } & $\mathrm{ADF}$ & -3.02 & 0.033 & 4695 \\
\hline & & $\mathrm{PP}$ & -2.725 & 0.070 & 4695 \\
\hline & \multirow{2}{*}{ No trend, no constant } & $\mathrm{ADF}$ & -2.712 & & 4695 \\
\hline & & $\mathrm{PP}$ & -2.475 & & 4695 \\
\hline
\end{tabular}

Note: The ADF and PP test critical values respectively are at 1 percent: $-3.960,5$ percent $\%$ : 3.410, 10 percent: -3.120 (Trend); 1 percent: $-3.430,5$ percent: -2.860 , 10 percent: -2.570 (No trend); 1 percent: $-2.580,5$ percent: $-1.950,10$ percent: -1.620 (No trend, no constant). PP test, ADF test $\left(\mathrm{H}_{0}\right.$ : series has a unit root). 
Table A2: Unit Root Tests (First Difference)

\begin{tabular}{|c|c|c|c|c|c|}
\hline Variable & & Tests & Statistic & P-value & Obs. \\
\hline \multirow{6}{*}{$\triangle \mathbf{J G B 2 Y}$} & \multirow{2}{*}{ Trend } & $\mathrm{ADF}$ & -65.732 & 0.000 & 4954 \\
\hline & & PP & -65.588 & 0.000 & 4954 \\
\hline & \multirow{2}{*}{ No trend } & $\mathrm{ADF}$ & -65.737 & 0.000 & 4954 \\
\hline & & PP & -65.594 & 0.000 & 4954 \\
\hline & \multirow{2}{*}{ No trend, no constant } & $\mathrm{ADF}$ & -65.740 & 0.000 & 4954 \\
\hline & & $\mathrm{PP}$ & -65.598 & 0.000 & 4954 \\
\hline \multirow{6}{*}{$\triangle \mathbf{J G B 3 Y}$} & \multirow{2}{*}{ Trend } & $\mathrm{ADF}$ & -65.395 & 0.000 & 4954 \\
\hline & & $\mathrm{PP}$ & -65.238 & 0.000 & 4954 \\
\hline & \multirow{2}{*}{ No trend } & $\mathrm{ADF}$ & -65.401 & 0.000 & 4954 \\
\hline & & $\mathrm{PP}$ & -65.244 & 0.000 & 4954 \\
\hline & \multirow{2}{*}{ No trend, no constant } & $\mathrm{ADF}$ & -65.404 & 0.000 & 4954 \\
\hline & & $\mathrm{PP}$ & -65.247 & 0.000 & 4954 \\
\hline \multirow{6}{*}{$\triangle$ JGB5Y } & \multirow{2}{*}{ Trend } & ADF & -68.112 & 0.000 & 4954 \\
\hline & & PP & -68.108 & 0.000 & 4954 \\
\hline & \multirow{2}{*}{ No trend } & ADF & -68.119 & 0.000 & 4954 \\
\hline & & $\mathrm{PP}$ & -68.115 & 0.000 & 4954 \\
\hline & \multirow{2}{*}{ No trend, no constant } & $\mathrm{ADF}$ & -68.119 & 0.000 & 4954 \\
\hline & & PP & -68.114 & 0.000 & 4954 \\
\hline \multirow{6}{*}{$\triangle \mathbf{J G B 6 Y}$} & \multirow{2}{*}{ Trend } & ADF & -71.015 & 0.000 & 4954 \\
\hline & & PP & -71.140 & 0.000 & 4954 \\
\hline & \multirow{2}{*}{ No trend } & ADF & -71.022 & 0.000 & 4954 \\
\hline & & $\mathrm{PP}$ & -71.147 & 0.000 & 4954 \\
\hline & \multirow{2}{*}{ No trend, no constant } & $\mathrm{ADF}$ & -71.021 & 0.000 & 4954 \\
\hline & & $\mathrm{PP}$ & -71.144 & 0.000 & 4954 \\
\hline \multirow{6}{*}{$\triangle J G B 7 Y$} & \multirow{2}{*}{ Trend } & ADF & -71.225 & 0.000 & 4954 \\
\hline & & PP & -71.309 & 0.000 & 4954 \\
\hline & \multirow{2}{*}{ No trend } & ADF & -71.233 & 0.000 & 4954 \\
\hline & & $\mathrm{PP}$ & -71.316 & 0.000 & 4954 \\
\hline & \multirow{2}{*}{ No trend, no constant } & $\mathrm{ADF}$ & -71.230 & 0.000 & 4954 \\
\hline & & $\mathrm{PP}$ & -71.312 & 0.000 & 4954 \\
\hline \multirow{6}{*}{$\triangle J G B 8 Y$} & \multirow{2}{*}{ Trend } & $\mathrm{ADF}$ & -72.696 & 0.000 & 4954 \\
\hline & & PP & -72.771 & 0.000 & 4954 \\
\hline & Notrond & ADF & -72.704 & 0.000 & 4954 \\
\hline & No trend & PP & -72.778 & 0.000 & 4954 \\
\hline & N t to 1 & $\mathrm{ADF}$ & -72.700 & 0.000 & 4954 \\
\hline & No trend, no constant & PP & -72.773 & 0.000 & 4954 \\
\hline & & ADF & -71.508 & 0.000 & 4954 \\
\hline & Trend & PP & -71.504 & 0.000 & 4954 \\
\hline & & $\mathrm{ADF}$ & -71.515 & 0.000 & 4954 \\
\hline$\triangle$ JGB9Y & No trend & $\mathrm{PP}$ & -71.511 & 0.000 & 4954 \\
\hline & No trend no conctant & $\mathrm{ADF}$ & -71.510 & 0.000 & 4954 \\
\hline & No trend, no constant & $\mathrm{PP}$ & -71.506 & 0.000 & 4954 \\
\hline & & ADF & -70.646 & 0.000 & 4954 \\
\hline & Trend & PP & -70.65 & 0.000 & 4954 \\
\hline & & ADF & -70.653 & 0.000 & 4954 \\
\hline$\triangle \mathrm{JGB10Y}$ & No trend & PP & -70.657 & 0.000 & 4954 \\
\hline & Notrend noconctant & $\mathrm{ADF}$ & -70.645 & 0.000 & 4954 \\
\hline & No trena, no constant & PP & -70.648 & 0.000 & 4954 \\
\hline
\end{tabular}




\begin{tabular}{|c|c|c|c|c|c|}
\hline Variable & & Tests & Statistic & P-value & Obs. \\
\hline \multirow{6}{*}{$\triangle$ JGB15Y } & \multirow{2}{*}{ Trend } & ADF & -71.796 & 0.000 & 4954 \\
\hline & & PP & -71.845 & 0.000 & 4954 \\
\hline & \multirow{2}{*}{ No trend } & $\mathrm{ADF}$ & -71.802 & 0.000 & 4954 \\
\hline & & PP & -71.851 & 0.000 & 4954 \\
\hline & \multirow{2}{*}{ No trend, no constant } & $\mathrm{ADF}$ & -71.794 & 0.000 & 4954 \\
\hline & & PP & -71.840 & 0.000 & 4954 \\
\hline \multirow{6}{*}{$\triangle \mathrm{JGB20Y}$} & \multirow{2}{*}{ Trend } & ADF & -46.749 & 0.000 & 2281 \\
\hline & & PP & -46.821 & 0.000 & 2281 \\
\hline & \multirow{2}{*}{ No trend } & ADF & -46.752 & 0.000 & 2281 \\
\hline & & $\mathrm{PP}$ & -46.823 & 0.000 & 2281 \\
\hline & \multirow{2}{*}{ No trend, no constant } & $\mathrm{ADF}$ & -46.705 & 0.000 & 2281 \\
\hline & & $\mathrm{PP}$ & -46.763 & 0.000 & 2281 \\
\hline \multirow{6}{*}{$\triangle$ JGB25Y } & \multirow{2}{*}{ Trend } & $\mathrm{ADF}$ & -45.369 & 0.000 & 2281 \\
\hline & & PP & -45.337 & 0.000 & 2281 \\
\hline & \multirow{2}{*}{ No trend } & ADF & -45.377 & 0.000 & 2281 \\
\hline & & PP & -45.345 & 0.000 & 2281 \\
\hline & \multirow{2}{*}{ No trend, no constant } & $\mathrm{ADF}$ & -45.337 & 0.000 & 2281 \\
\hline & & $\mathrm{PP}$ & -45.299 & 0.000 & 2281 \\
\hline \multirow{6}{*}{$\triangle \mathrm{JGB30Y}$} & \multirow{2}{*}{ Trend } & $\mathrm{ADF}$ & -59.275 & 0.000 & 4064 \\
\hline & & $\mathrm{PP}$ & -59.119 & 0.000 & 4064 \\
\hline & \multirow{2}{*}{ No trend } & $\mathrm{ADF}$ & -59.231 & 0.000 & 4064 \\
\hline & & PP & -59.074 & 0.000 & 4064 \\
\hline & \multirow{2}{*}{ No trend, no constant } & $\mathrm{ADF}$ & -59.238 & 0.000 & 4064 \\
\hline & & PP & -59.081 & 0.000 & 4064 \\
\hline \multirow{6}{*}{$\Delta \mathbf{J G B 4 0 Y}$} & \multirow{2}{*}{ Trend } & ADF & -43.597 & 0.000 & 2281 \\
\hline & & $\mathrm{PP}$ & -43.451 & 0.000 & 2281 \\
\hline & \multirow{2}{*}{ No trend } & ADF & -43.607 & 0.000 & 2281 \\
\hline & & PP & -43.461 & 0.000 & 2281 \\
\hline & \multirow{2}{*}{ No trend, no constant } & $\mathrm{ADF}$ & -43.585 & 0.000 & 2281 \\
\hline & & $\mathrm{PP}$ & -43.442 & 0.000 & 2281 \\
\hline \multirow{6}{*}{$\Delta \mathrm{TB3M}$} & Trend & $\mathrm{ADF}$ & -75.327 & 0.000 & 4531 \\
\hline & 17end & $\mathrm{PP}$ & -77.249 & 0.000 & 4531 \\
\hline & No trend & $\mathrm{ADF}$ & -75.330 & 0.000 & 4531 \\
\hline & so tichu & PP & -77.240 & 0.000 & 4531 \\
\hline & No trend no constant & $\mathrm{ADF}$ & -75.337 & 0.000 & 4531 \\
\hline & po tiend, ive constant & PP & -77.247 & 0.000 & 4531 \\
\hline & Trend & ADF & -68.111 & 0.000 & 4954 \\
\hline & rena & $\mathrm{PP}$ & -68.106 & 0.000 & 4954 \\
\hline ATOPIY & No trand & ADF & -68.101 & 0.000 & 4954 \\
\hline$\triangle \mathrm{FOPIX}$ & No trend & PP & -68.093 & 0.000 & 4954 \\
\hline & & $\mathrm{ADF}$ & -68.107 & 0.000 & 4954 \\
\hline & No trend, no constant & PP & -68.100 & 0.000 & 4954 \\
\hline & Trend & ADF & -72.675 & 0.000 & 4954 \\
\hline & Irena & PP & -72.738 & 0.000 & 4954 \\
\hline NUKKE & No trond & ADF & -72.650 & 0.000 & 4954 \\
\hline$\triangle$ NIKREI & No trend & PP & -72.707 & 0.000 & 4954 \\
\hline & No trond no constont & ADF & -72.657 & 0.000 & 4954 \\
\hline & vo trend, no constant & PP & -72.714 & 0.000 & 4954 \\
\hline$\triangle J P Y U S D$ & Trend & ADF & -71.570 & 0.000 & 4954 \\
\hline
\end{tabular}




\begin{tabular}{|c|c|c|c|c|c|}
\hline Variable & & Tests & Statistic & P-value & Obs. \\
\hline & & $\mathrm{PP}$ & -71.605 & 0.000 & 4954 \\
\hline & No trond & $\mathrm{ADF}$ & -71.577 & 0.000 & 4954 \\
\hline & No trend & PP & -71.612 & 0.000 & 4954 \\
\hline & & $\mathrm{ADF}$ & -71.584 & 0.000 & 4954 \\
\hline & No trend, no constant & PP & -71.619 & 0.000 & 4954 \\
\hline \multirow{6}{*}{$\triangle J P Y E U R$} & \multirow{2}{*}{ Trend } & $\mathrm{ADF}$ & -69.654 & 0.000 & 4954 \\
\hline & & PP & -69.654 & 0.000 & 4954 \\
\hline & \multirow{2}{*}{ No trend } & $\mathrm{ADF}$ & -69.656 & 0.000 & 4954 \\
\hline & & $\mathrm{PP}$ & -69.655 & 0.000 & 4954 \\
\hline & \multirow{2}{*}{ No trend, no constant } & $\mathrm{ADF}$ & -69.661 & 0.000 & 4954 \\
\hline & & $\mathrm{PP}$ & -69.661 & 0.000 & 4954 \\
\hline \multirow{6}{*}{$\Delta$ INFL } & \multirow{2}{*}{ Trend } & $\mathrm{ADF}$ & -70.174 & 0.000 & 4694 \\
\hline & & $\mathrm{PP}$ & -70.543 & 0.000 & 4694 \\
\hline & \multirow{2}{*}{ No trend } & $\mathrm{ADF}$ & -70.180 & 0.000 & 4694 \\
\hline & & PP & -70.548 & 0.000 & 4694 \\
\hline & \multirow{2}{*}{ No trend, no constant } & $\mathrm{ADF}$ & 70.186 & 0.000 & 4694 \\
\hline & & PP & -70.553 & 0.000 & 4694 \\
\hline
\end{tabular}

Note: The ADF and PP test critical values are 1 percent: $-3.960,5$ percent: $-3.410,10$ percent: -3.120 (Trend); 1 percent: $-3.430,5$ percent: $-2.860,10$ percent: -2.570 (No trend); 1 percent: $-2.580,5$ percent: -1.950 , 10 percent: 1.620 (No trend, no constant). PP test, ADF test (H0: series has a unit root). 